Prepared for the U.S. Department of Energy under Contract DE-AC05-76RL01830

\title{
Air Conditioner Compressor Performance Model
}

N Lu

YL Xie

Z Huang

August 2008

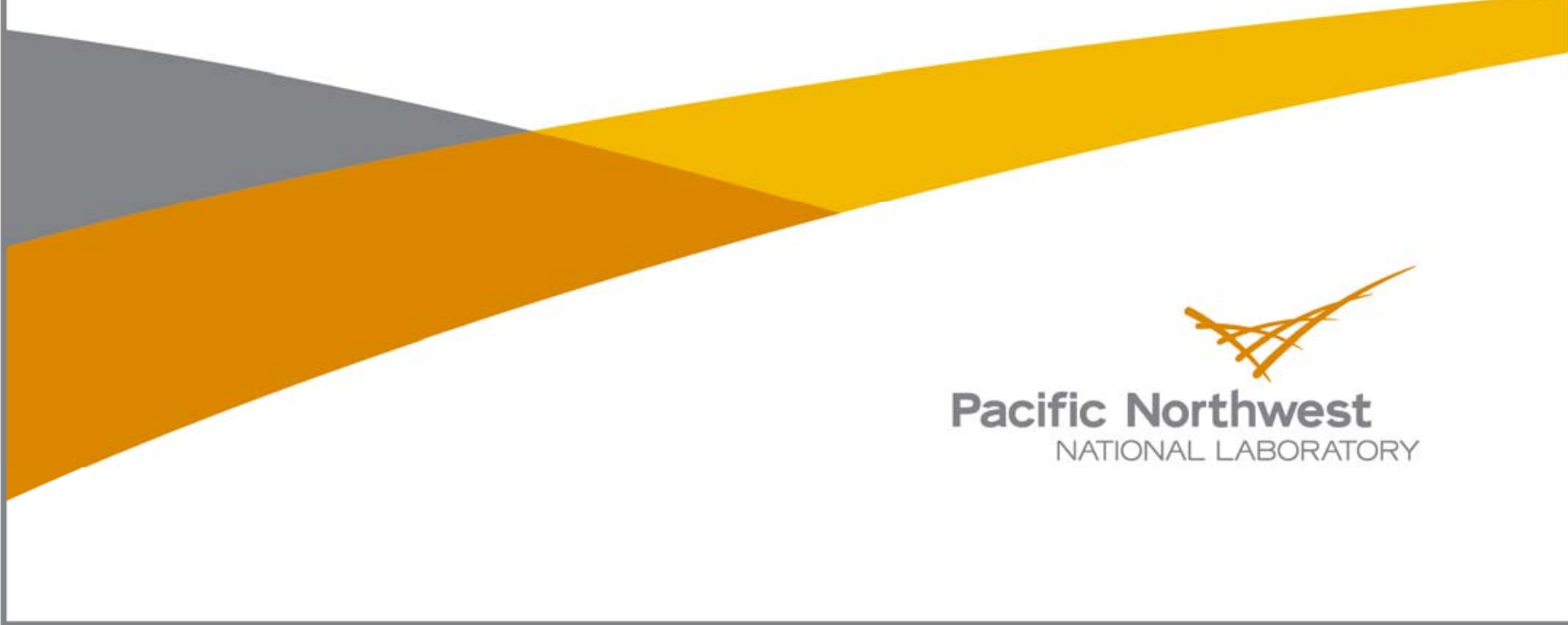





\section{DISCLAIMER}

United States Government. Neither the United States Government nor any agency thereof, nor Battelle Memorial Institute, nor any of their employees, makes any warranty, express or implied, or assumes any legal liability or responsibility for the accuracy, completeness, or usefulness of any information, apparatus, product, or process disclosed, or represents that its use would not infringe privately owned rights. Reference herein to any specific commercial product, process, or service by trade name, trademark, manufacturer, or otherwise does not necessarily constitute or imply its endorsement, recommendation, or favoring by the United States Government or any agency thereof, or Battelle Memorial Institute. The views and opinions of authors expressed herein do not necessarily state or reflect those of the United States Government or any agency thereof.

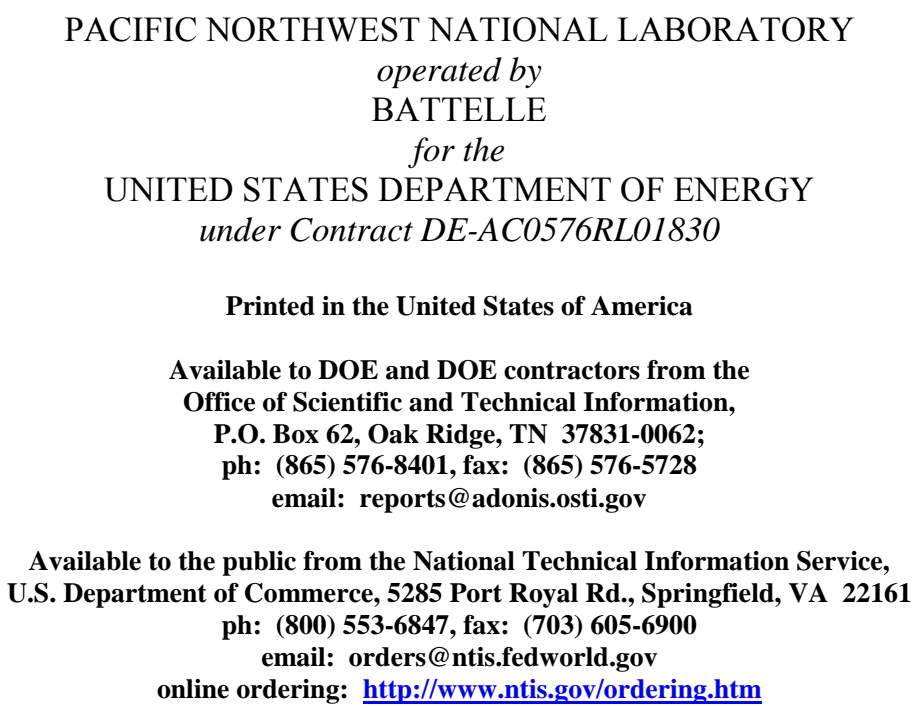

\section{LEGAL NOTICE}

This report was prepared as a result of work sponsored by the California Energy Commission (CEC) and the University of California (UC), and performed by Pacific Northwest National Laboratory (PNNL). It does not necessarily represent the views of CEC, PNNL, UC, their employees, or the State of California. CEC, the State of California, its employees, PNNL, and UC make no warranty, expressed or implied, and assume no legal liability for the information in this report; nor does any party represent that the use of this information will not infringe upon privately owned rights. This report has not been approved or disapproved by CEC, PNNL, or UC, nor has CEC, PNNL, or $\mathrm{UC}$ passed upon the accuracy or adequacy of the information in this report. 



\title{
Air Conditioner Compressor Performance Model
}

\author{
$\mathrm{N} \mathrm{Lu}$ \\ Y Xie \\ Z Huang
}

August 2008

Prepared for

Lawrence Berkeley National Laboratory

for the

California Energy Commission under Contract DE-AC05-76RL01830

Pacific Northwest National Laboratory

Richland, Washington 99352 



\section{Summary}

In recent years, phasor measurement units (PMUs) have recorded more and more slow voltage recovery (SVR) events in the electrical grid, especially in areas supplying heavy air-conditioning loads. The sustained low voltages have caused power quality issues and raised concerns about system voltage collapse. Meanwhile, the significant reduction in voltage stability margin may lead to a similar chain of events. For these reasons, it is critical that SVR events be modeled and prevented to assure that the system voltage recovers to its nominal value in a few seconds.

Fundamentally, SVR events are caused by stalled compressors inside single-phase air-conditioning (SPAC) units, which can not be simulated satisfactorily by either three-phase motor models or ZIP models. Therefore, a new modeling approach is needed.

During the past years, the Western Electricity Coordinating Council (WECC) Load Modeling Task Force (LMTF) has led the effort to develop the new modeling approach. As part of this effort, the Bonneville Power Administration (BPA), Southern California Edison (SCE), and Electric Power Research Institute (EPRI) Solutions tested 27 residential air-conditioning units to assess their response to delayed voltage recovery transients. After completing these tests, different modeling approaches were proposed, among them a performance modeling approach that proved to be one of the three favored for its simplicity and ability to recreate different SVR events satisfactorily.

Funded by the California Energy Commission (CEC) via Lawrence Berkeley National Laboratory under its load modeling project, researchers at Pacific Northwest National Laboratory (PNNL) led the follow-on task to analyze the motor testing data to derive the parameters needed to develop a performance model for the SPAC unit. To derive the performance model, PNNL researchers first used the motor voltage and frequency ramping test data to obtain the real $(P)$ and reactive $(Q)$ power versus voltage $(V)$ and frequency $(f)$ curves. Then, curve fitting was used to develop the P-V, Q-V, P-f, and Q-f relationships for motor running and stalling states. The resulting performance model ignores the dynamic response of the air-conditioning motor. Because the inertia of the air-conditioning motor is very small $(\mathrm{H}<0.05)$, the motor reaches from one steady state to another in a few cycles, so, the performance model is a fair representation of the motor behaviors in both running and stalling states. 


\section{Acknowledgment}

The preparation of this report was conducted with support from the California Energy Commission's Public Interest Energy Research Program, WA\# MR-049, through the California Institute of Energy and Environment, Award Number MTX-06-01, and support from Pacific Northwest National Laboratory.

The authors would like to thank Richard Bravo, Southern California Edison, and Dmitry Kosterev, Bonneville Power Administration, for providing PNNL with the air-conditioner testing data and contributing to many insightful discussions. This work is supported by the California Institute for Energy and Environment (CIEE) and California Energy Commission. 


\section{Acronyms and Abbreviations}

$\begin{array}{ll}\text { AC } & \text { air conditioner } \\ \text { BPA } & \text { Bonneville Power Administration } \\ \text { CEC } & \text { California Energy Commission } \\ \text { CIEE } & \text { California Institute for Energy and Environment } \\ \text { EPRI } & \text { Electric Power Research Institute } \\ \text { HVAC } & \text { heating, ventilation, and air-conditioning } \\ \text { LMFT } & \text { Load Modeling Task Force } \\ \text { PMU } & \text { phasor measurement unit } \\ \text { PNNL } & \text { Pacific Northwest National Laboratory } \\ \text { SCE } & \text { Southern California Edison } \\ \text { SPAC } & \text { single-phase air-conditioning } \\ \text { SVR } & \text { slow voltage recovery } \\ \text { WECC } & \text { Western Electricity Coordinating Council }\end{array}$




\section{Contents}

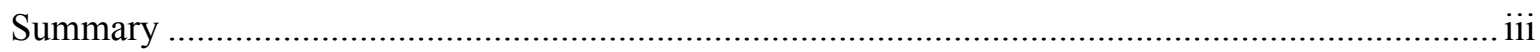

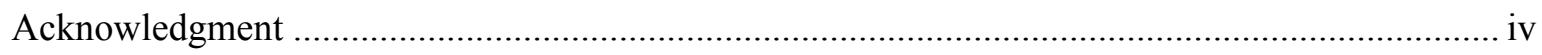

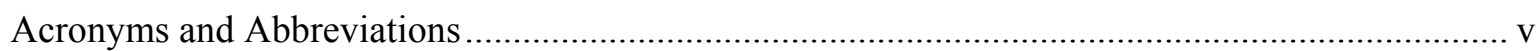

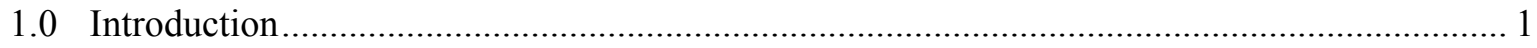

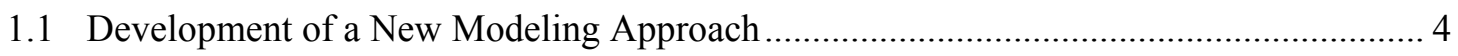

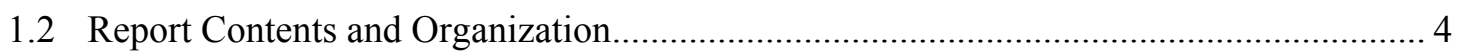

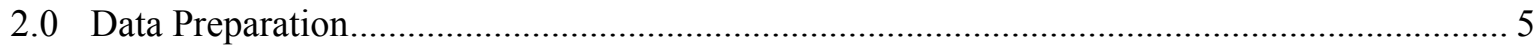

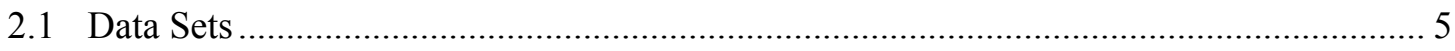

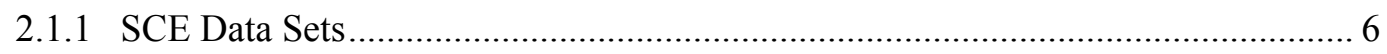

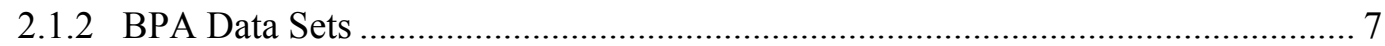

2.2 Data Preprocessing: Filtering and Normalization................................................... 8

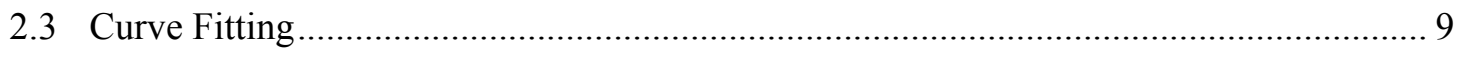

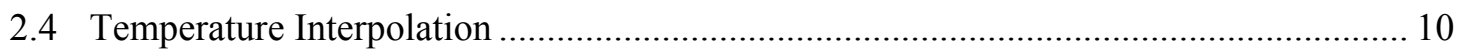

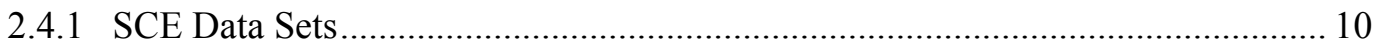

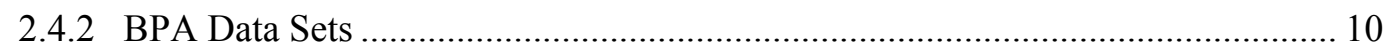

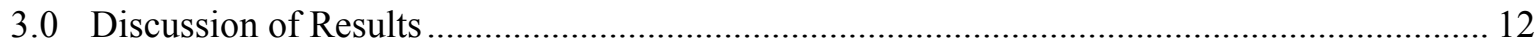

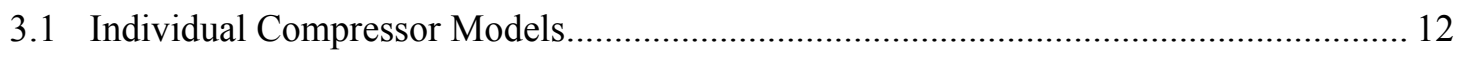

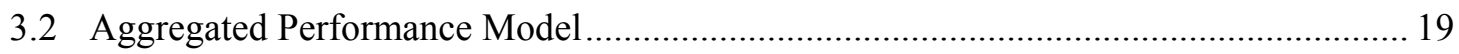

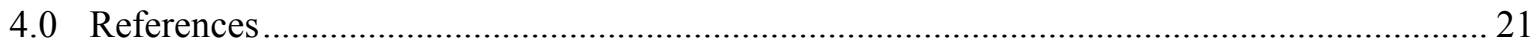




\subsection{Introduction}

In recent years, phasor measurement units (PMUs) have recorded more and more slow voltage recovery (SVR) events in the electrical grid, especially in areas supplying heavy air conditioning loads. During an SVR event, the voltage recovers to the nominal level in tens of seconds instead of tens of cycles after a fault is cleared (the faults are usually cleared in three to five cycles at the transmission level). Sustained low voltages have caused power quality issues and raised concerns of voltage system collapse. Meanwhile, the significant reduction in the voltage stability margin may lead to a similar chain of events. Therefore, it is critical that SVR events be modeled and prevented.

Most heating, ventilation, and air-conditioning (HVAC) units used by households and small business buildings are single-phase air-conditioning (SPAC) units, which include a condenser fan, an air handler fan, and a compressor, as shown in Figure 1 and Figure 2. The two fans consume approximately $20 \%$ of the total power of an air-conditioning unit, while the compressor consumes $80 \%$ of the total power under normal operating conditions. The air handler and condenser fan motors can be modeled by either three-phase motor models or ZIP models, because these motors restart when voltage recovers, as shown in Figure 3 and Figure 4.

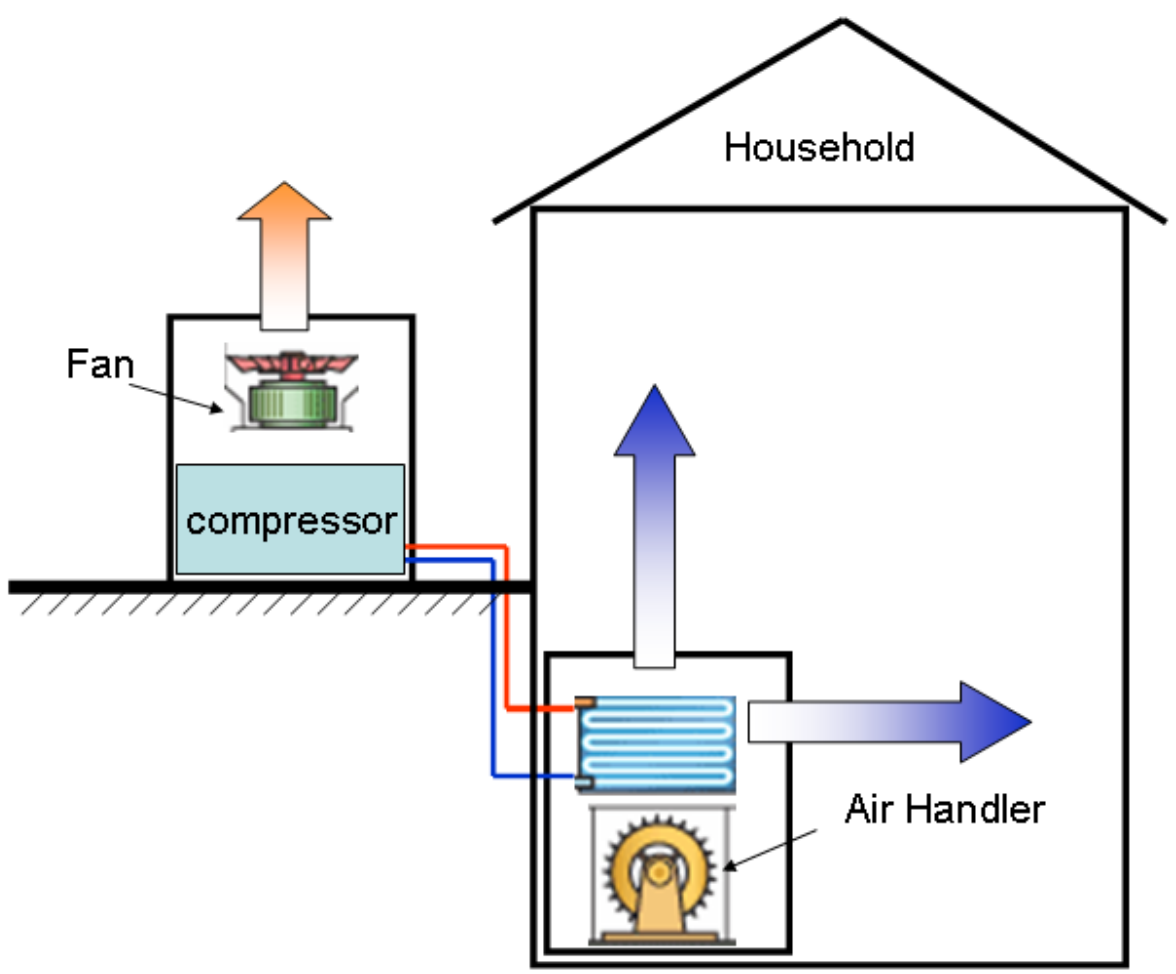

Figure 1. The Configuration of an Air-Conditioner Unit

For the compressor motor, however, once the fault voltage drops below its stalling threshold (usually around 0.6 to 0.7 p.u.), the motor stalls in a few cycles. This is because the pressurized gas in the compression pipes produces a constant torque on the motor shaft, and the electrical torque can not overcome the load torque once the voltage drops below a certain threshold. Once stalled, the compressor motor current jumps to three to seven times its rated value when the fault is cleared and the voltage starts to recover. This over-current condition 
produces a voltage drop, the magnitude of which depends on the amount of stalled motor and the feeder impedance. Under such depressed voltage conditions, the motor electrical torque is not able to overcome the motor load torque. Thus, the compressor motor remains stalled until its thermal relay detects the over-current and trips the compressor offline. Depending on the magnitude of the over-current, the process, can take from seconds to tens of seconds, as shown in Figure 5. Therefore, the fundamental cause of the SVR event is the stalled motors inside a SPAC unit. Because neither the three-phase motor model nor the ZIP model alone can model the compressor behavior properly for both the motor running and stalling states, a new modeling approach is needed for the modeling of SPAC units.
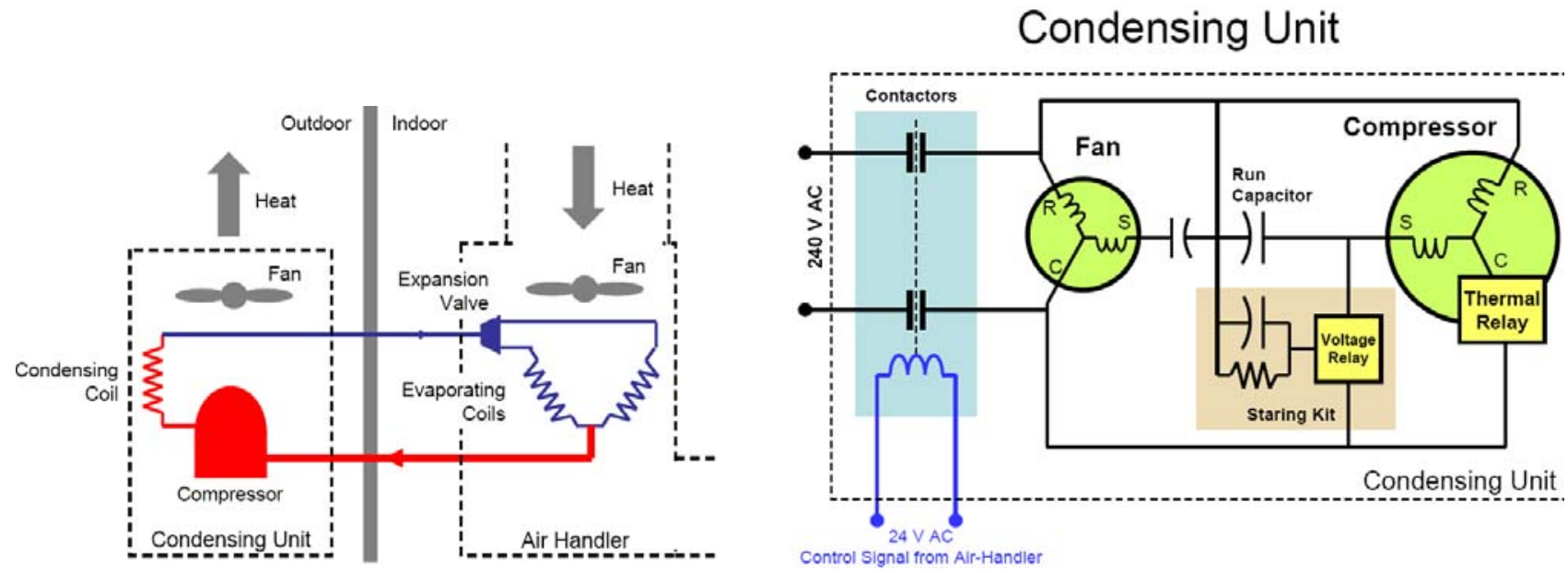

Figure 2. The Electrical System of an Air Conditioner (Kosterev 2007)
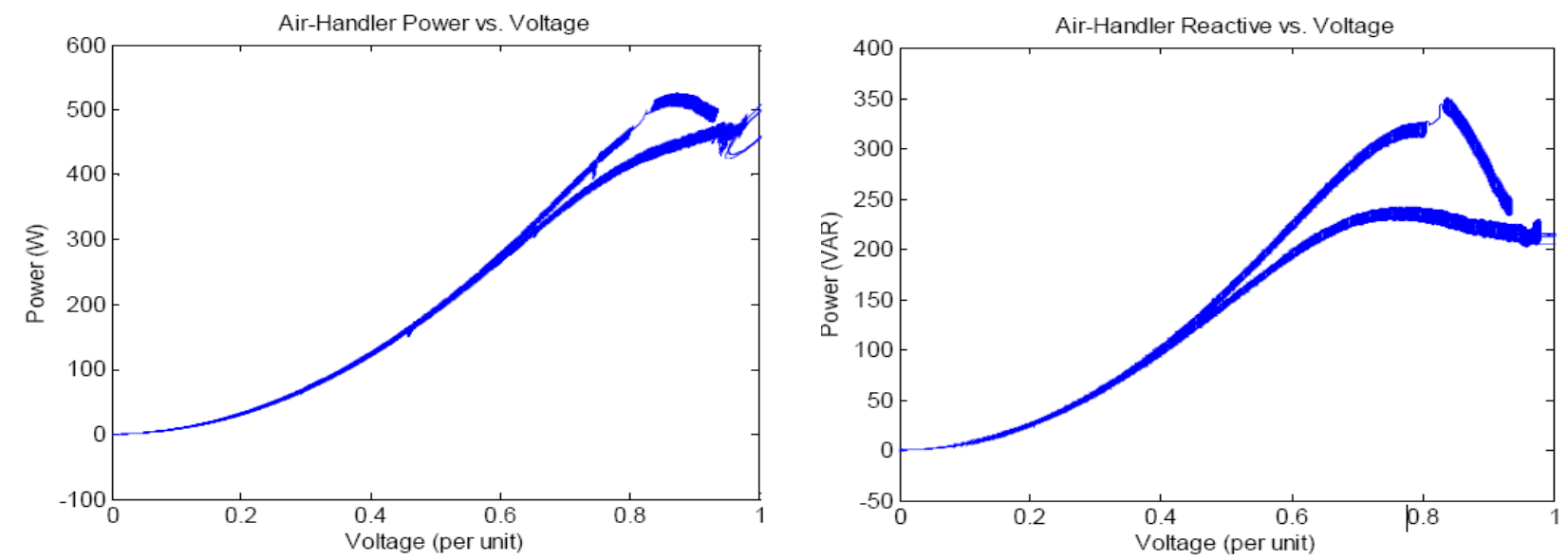

Figure 3. The P-V and Q-V Curves of the Air-Handler Inside an Air-Conditioner Unit (Kosterev 2007) 


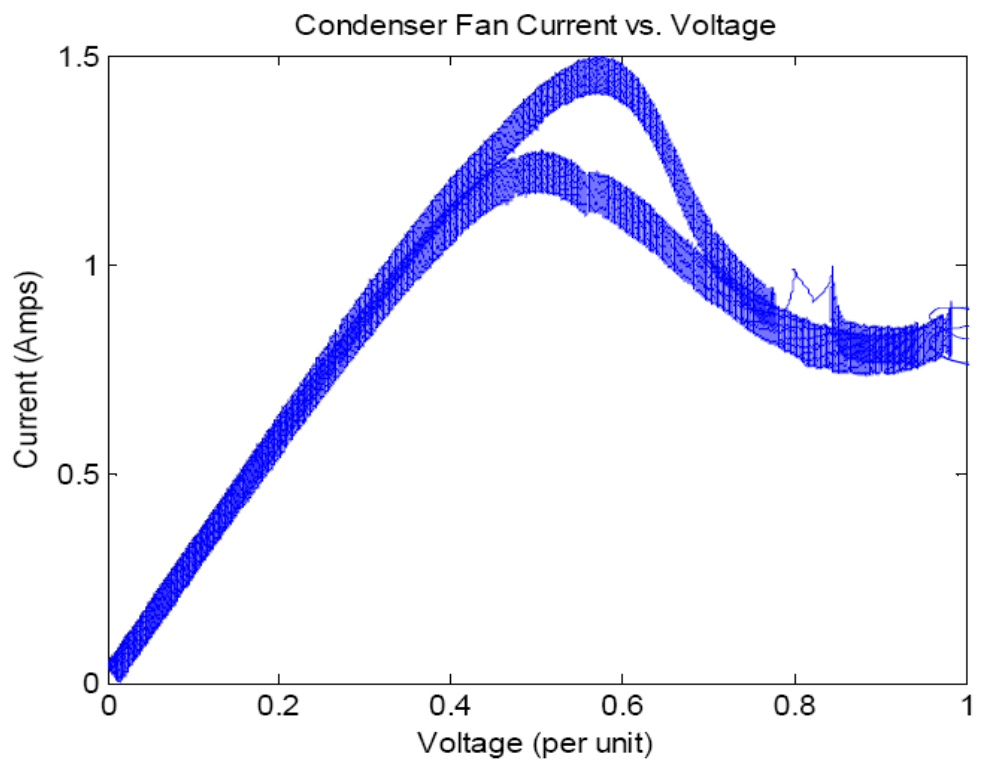

Figure 4. The P-V and Q-V Curves of the Condenser Fan Inside an Air-Conditioner Unit (Kosterev 2007)

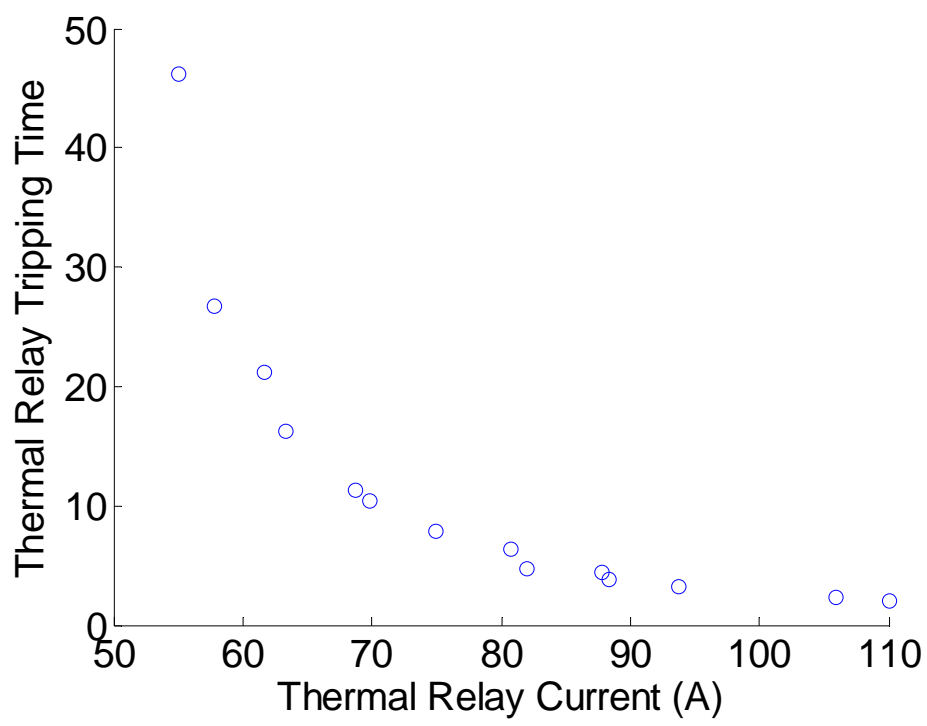

Figure 5. Thermal Relay Testing Results 


\subsection{Development of a New Modeling Approach}

During the past years, the Western Electricity Coordinating Council (WECC) Load Modeling Task Force (LMTF) has led the effort to develop the new modeling approach. Under the auspices of the WECC LMTF, the Bonneville Power Administration (BPA), Southern California Edison, and Electric Power Research Institute (EPRI) Solutions tested 27 residential air-conditioning units to assess their response to delayed voltage recovery transients. As a result of the tests, three modeling approaches were proposed: 1) the performance modeling approach, which is an empirical model derived from the motor testing results; 2) the hybrid modeling approach, which uses a three-phase motor model to represent the motor running state and a performance model to represent the motor stalling state; and 3) the single-phase positive-sequence modeling approach, which is derived from the voltage and torque equations for the single-phase induction motor.

Funded by the California Energy Commission (CEC) via Lawrence Berkeley National Laboratory under its load modeling project, researchers at Pacific Northwest National Laboratory (PNNL) led the follow-on task to analyze the motor testing data and derive from them the parameters of the performance models for the SPAC unit. Using the motor voltage and frequency ramping test data, the researchers obtained the real $(P)$ and reactive $(Q)$ power versus voltage $(V)$ and frequency $(f)$ curves. They then used curve fitting to develop the P-V, Q-V, P$\mathrm{f}$, and Q-f functions for both the motor running and stalling states. The temperature influence on the stalling voltages and the P-V and Q-V curves was obtained under three testing ambient temperatures $-80,100$, and $115^{\circ} \mathrm{F}$. A thermal relay model also was derived from the thermal relay testing data to represent the tripping of the stalled motors with respect to motor stalling current and stalling time. As a result of these efforts, an aggregated performance model to simulate the accumulated air-conditioner behavior at the feeder head is proposed.

\subsection{Report Contents and Organization}

This report summarizes PNNL's efforts to derive the performance model for the SPAC. Section 2.0 presents the data preparation and data analysis methodology; i.e., it describes the preparation of the data used to derive the performance model, including the compressor and thermal relay testing data sets provided by BPA and SCE, data preprocessing, curve fitting, and temperature interpolation. Section 3.0 presents a discussion of the results, describing and illustrating the components of a performance model representing an individual SPAC unit and discussing the aggregation of individual models. Plot measurement data versus curve-fitting results for BPAtested and SCE-tested motors are provided in Appendixes A and B, respectively.

Bravo et al. (2006) provide more detailed description of the testing setups. Kosterev (2007), Lu and Huang (2008), and $\mathrm{Lu}$ and Qiao (2007) provide the performance model specifications and model validations. Lu et al. (2008a, 2008b) provide a practical application of the performance model. The modeling validation task was carried out in a separate process, so it is not included in this report. 


\subsection{Data Preparation}

Deriving a performance model for the SPAC unit required data preparation that involved the use of data sets, data preprocessing, curve fitting, and temperature interpolation, as described in the following sections.

\subsection{Data Sets}

As indicated previously, the data used in this modeling task were provided by BPA and SCE. A total of 19 air-conditioner compressor units were tested; 9 by BPA and 10 by SCE. Because the data sets for 3 units tested by BPA and 3 tested by SCE were incomplete, only 13 complete data sets are shown in Table 1 . These data sets include the following testing scenarios: voltage ramp-down and ramp-up, voltage oscillation, voltage sags, frequency oscillation, frequency ramp-down and ramp-up. The units were tested under different ambient temperatures as follows:

- BPA: Most motors were tested under $95^{\circ} \mathrm{F}$.

- SCE: Motors were tested under 80,100 , and $115^{\circ} \mathrm{F}$.

Table 1. Air-Conditioner Units Tested

\begin{tabular}{|c|c|}
\hline Air-Conditioner Name & Agency \\
\hline 1. Carrier 3-Ton Recip 38TKB036 & \multirow{6}{*}{ BPA } \\
\hline 2. Payne 3-Ton Scroll PA12NA036 & \\
\hline 3. Trane 3-Ton Recip 2TTB0036A & \\
\hline 4. York 3.5-Ton Recip H4DB042S06 & \\
\hline 5. York 4-Ton Scroll H5DB048S06 & \\
\hline 6. York 3-Ton Recip H4DB036S06 & \\
\hline 7. AC10-Carrier 5-Ton Scroll & \\
\hline 8. AC3-Rheem 3-Ton Scroll & \\
\hline 9. AC4-Carrier 3-Ton Scroll & \\
\hline 10. AC5-Coleman 4-Ton Scroll & SCE \\
\hline 11. AC6-Rheem 4-Ton Scroll & \\
\hline 12. AC7-Carrier 4-Ton Scroll & \\
\hline 13. AC8-Goodman 4-Ton Recip & \\
\hline
\end{tabular}

The detailed experimental setup and data collection process were documented by SCE (Yinger et al. 2006; Bravo et al. 2006). 


\subsubsection{SCE Data Sets}

SCE provided PNNL with 10 sets of air-conditioner compressor testing data. The data were organized according to the air-conditioner (AC) index, as shown in Table 1. Three ambient temperatures were considered: 80,100 , and $115^{\circ} \mathrm{F}$. There were a few bad data sets among them:

- Data for AC 1 are incomplete and in a different file format than the other testing records.

- Data for AC 2 are not accessible.

- Data for $\mathrm{AC} 9$ at $100^{\circ} \mathrm{F}$ are not accessible.

Therefore, only the data sets for the remaining seven AC units tested were used to derive the performance model; the filenames are listed in Table 2. There are 15 fields in the SCE-provided CSV data files. According to Table 1 in SCE's documentation (Yinger et al. 2006), the following three fields were used subsequently: MATH 1 of input voltage, MATH 9 of total real power, and MATH 10 of total apparent power (see Tables 3 and 4).

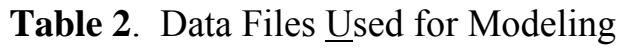

\begin{tabular}{l}
\hline \multicolumn{1}{c}{ Name of Data File } \\
\hline AC3_TS101_Ramp_70\%115F.csv \\
\hline AC3_TS84_Ramp_70\%80F.csv \\
\hline AC3_TS88_Ramp_70\%100F.csv \\
\hline AC4_TS66_Ramp_10\%100F.csv \\
\hline AC4_TS69_Ramp_70\%80F.csv \\
\hline AC4_TS83_Ramp_10\%115F.csv \\
\hline AC5_TS67_Ramp_10\%100F.csv \\
\hline AC5_TS67_Ramp_10\%80F.csv \\
\hline AC5_TS77_Ramp_115F.csv \\
\hline AC6_TS55_Ramp_10\%80F.csv \\
\hline AC6_TS60_Ramp_60\%100F.csv \\
\hline AC6_TS96_Ramp_10\%115F.csv \\
\hline AC7_TS80_Ramp_10\%100F.csv \\
\hline AC7_TS84_Ramp_10\%80F.csv \\
\hline AC7_TS85_Ramp_10\%115F.csv \\
\hline AC8_TS63_Ramp_10\%100F.csv \\
\hline AC8_TS69_Ramp_10\%115F.csv \\
\hline AC8_TS74_Ramp_10\%80F.csv \\
\hline AC10_TS69_Ramp_10\%80F.csv \\
\hline AC10_TS71_Ramp_10\%100F.csv \\
\hline AC10_TS77_Ramp_10\%115F.csv \\
\hline
\end{tabular}


Table 3. A Description of the Data Sets

\begin{tabular}{|l|l|l|l|}
\hline \multirow{2}{*}{ Tag } & \multicolumn{1}{|c|}{ Description } & \multicolumn{2}{c|}{ Yokogawa } \\
\cline { 3 - 4 } & & Math & \multicolumn{1}{c|}{ Expression } \\
\hline $\mathrm{V}_{1}$ & Input Voltage & 1 & Trend(C1) \\
\hline $\mathrm{V}_{2}$ & Compressor Motor Running Winding Voltage & 3 & Trend(C3) \\
\hline $\mathrm{V}_{3}$ & Capacitor Voltage & 5 & Trend(C5) \\
\hline $\mathrm{V}_{4}$ & Compressor Motor Start Winding Voltage & 7 & Trend(C7) \\
\hline $\mathrm{I}_{1}$ & Input Current & 2 & Trend(C2) \\
\hline $\mathrm{I}_{2}$ & Compressor Motor Running Winding Current & 4 & Trend(C4) \\
\hline $\mathrm{I}_{3}$ & Fan Motor Current & 6 & Trend(C6) \\
\hline $\mathrm{I}_{4}$ & Compressor Motor Start Winding Current & 8 & Trend(C8) \\
\hline
\end{tabular}

Table 4. A Description of the Data Sets

\begin{tabular}{|l|l|l|l|}
\hline \multirow{2}{*}{ Tag } & \multicolumn{1}{c|}{ Description } & \multicolumn{2}{c|}{ Yokogawa } \\
\cline { 3 - 4 } & & \multicolumn{1}{c|}{ Math } & \multicolumn{1}{c|}{ Expression } \\
\hline $\mathrm{W}_{1}$ & Total Real Power & 9 & Trend $\left(\mathrm{C} 1{ }^{*} \mathrm{C} 2\right)$ \\
\hline $\mathrm{W}_{2}$ & Compressor Motor Running Winding Real Power & 11 & Trend $\left(\mathrm{C} 3{ }^{*} \mathrm{C} 4\right)$ \\
\hline $\mathrm{W}_{3}$ & Compressor Motor Start Winding Real Power & 13 & Trend $\left(\mathrm{C} 7{ }^{*} \mathrm{C} 8\right)$ \\
\hline $\mathrm{F}$ & Frequency & 15 & Trend $(\mathrm{C} 1)$ \\
\hline $\mathrm{VA}_{1}$ & Total Apparent Power & 10 & Trend(C1)*Trend(C2) \\
\hline $\mathrm{VA}_{2}$ & Compressor Motor Running Winding Apparent Power & 12 & Trend(C3)*Trend(C4) \\
\hline $\mathrm{VA}_{3}$ & Compressor Motor Start Apparent Power & 14 & Trend(C7)*Trend(C8) \\
\hline
\end{tabular}

\subsubsection{BPA Data Sets}

Testing data for nine AC units at various compressor and ambient temperatures were provided by BPA. Table 5 lists the names of the AC units, the data ramp-down and ramp-up files, and the temperatures for testing. Each block in Table 5 is designated for one AC compressor. Two AC compressors - the 0.5 Ton Room AC and 1.0 Ton Room $A C$ - have different data formats and therefore are not considered in this modeling task. Curve fitting was conducted on all of the data files for the remaining seven AC compressors. The curve-fitting parameters on selected temperatures for each AC compressor were then subjected to polynomial fitting for interpolation at any temperatures in the temperature range being tested. 
Table 5. Data Files Used for Modeling by AC Unit

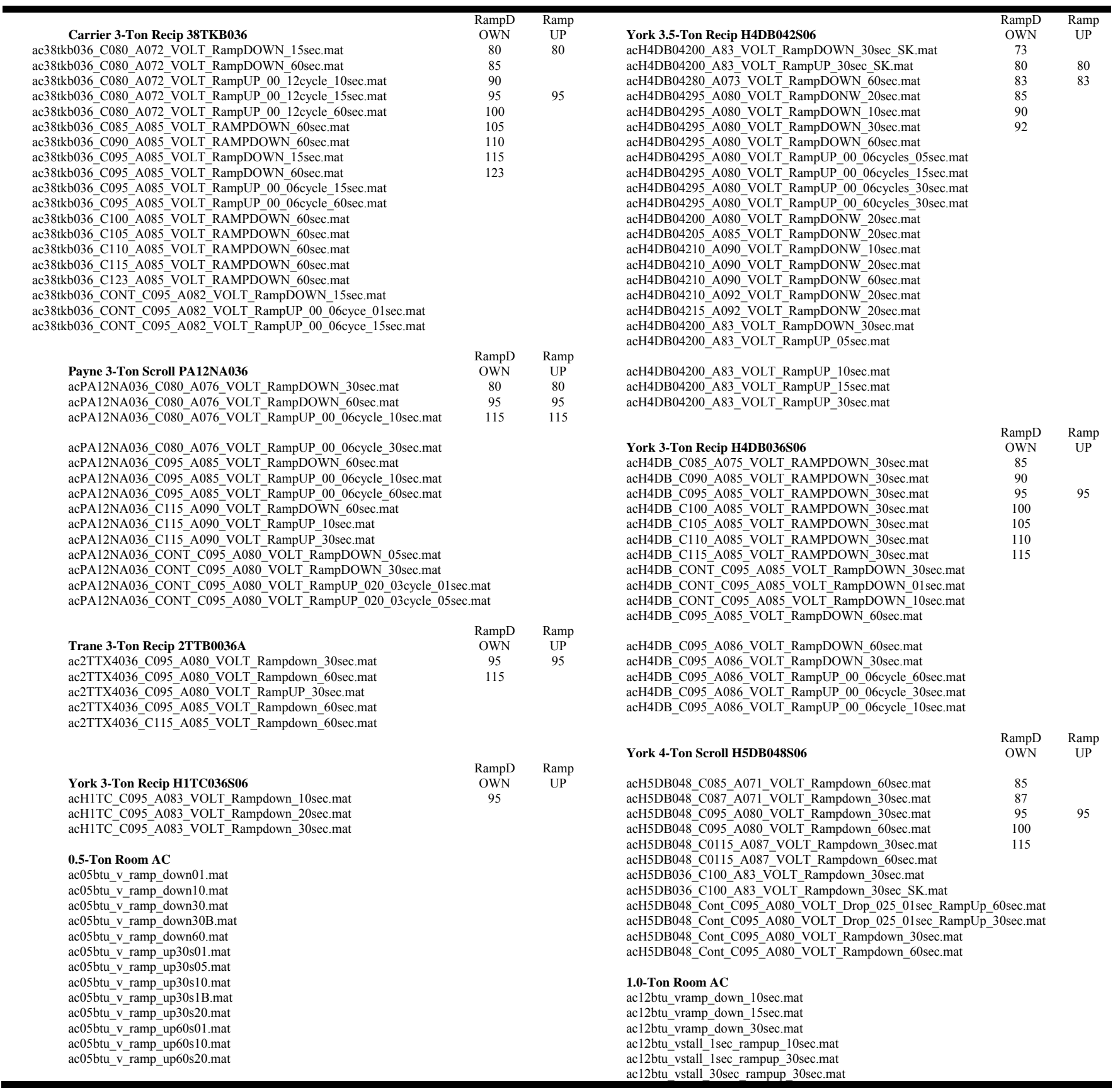

\subsection{Data Preprocessing: Filtering and Normalization}

To reduce the high frequency oscillation of the time series data, an averaging filter was applied on the time series. Data segments for ramp-down and ramp-up processes were then selected from the entire time series for subsequent curve fitting. 
The subsequent curve fitting was conducted on both raw time series data and normalized data, which are normalized by the motor apparent power defined as:

$$
S=\sqrt{P^{2}+Q^{2}}
$$

\subsection{Curve Fitting}

The following functions were selected for curve fitting to minimize the simulation errors for the voltage ramp-down, ramp-up, and oscillation cases:

1) For ramp-down:

$$
y=b_{1}+\frac{b_{2}}{x-b_{0}}+b_{3}\left(x-b_{0}\right)+b_{4}\left(x-b_{0}\right)^{4}
$$

2) For ramp-up:

$$
y=k_{1} x^{3}+k_{2} x^{2}
$$

where $x$ is the voltage and $y$ denotes raw or normalized real power $P$ or reactive power $Q$, as shown in Figure 6.

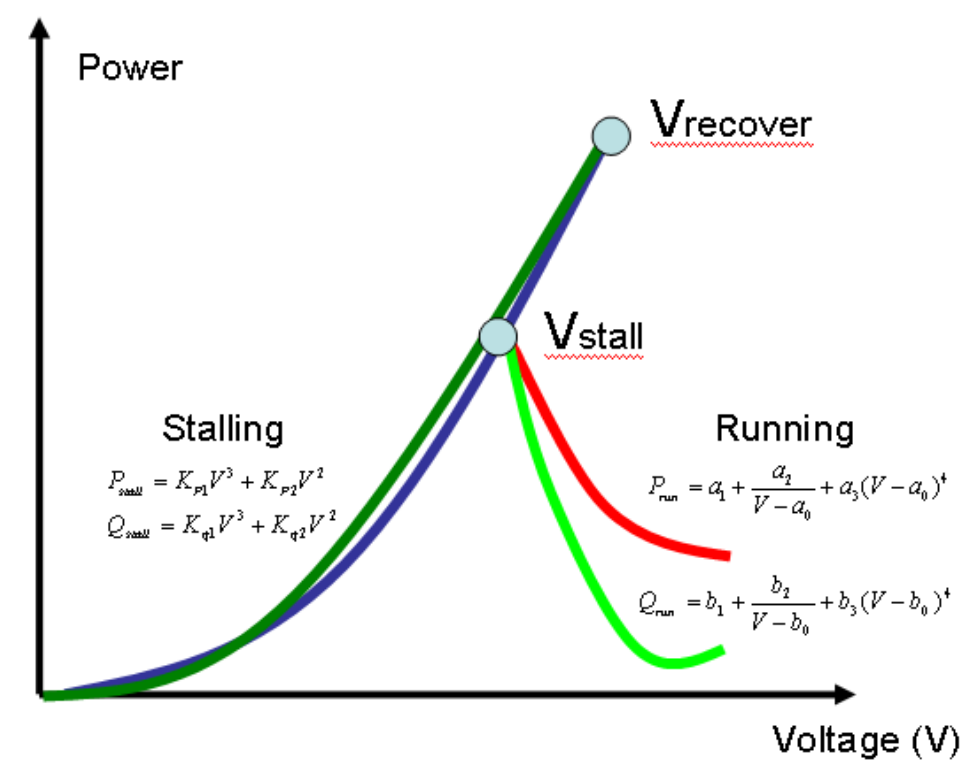

Figure 6. The P-V and Q-V Curves

For each AC compressor motor, fitting parameters were optimized for the $\mathrm{P}-\mathrm{V}$ and $\mathrm{Q}-\mathrm{V}$ curves of the rampdown and ramp-up processes at each of the three temperatures: 80,100 , and $115^{\circ} \mathrm{F}$, respectively. 
As shown in Figure 6, the other two sets of important parameters are the critical voltages, $V_{\text {stall, }}$, below which

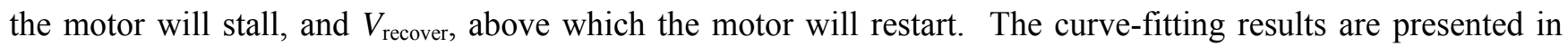
Appendixes A and B of this report.

\subsection{Temperature Interpolation}

Temperature was interpolated for the SCE and BPA data sets, as described here.

\subsubsection{SCE Data Sets}

The curve-fitting parameters of the P-V and Q-V curves and the peak voltage of the power time series at any temperature between $80^{\circ} \mathrm{F}$ and $115^{\circ} \mathrm{F}$ were interpolated. The interpolation was based on a polynomial fitting of each of the fitting parameters based on the optimal fitting parameters at three temperatures. The P-V and Q-V curves at any temperatures between $80^{\circ} \mathrm{F}$ and $115^{\circ} \mathrm{F}$ could therefore be simulated. A second order polynomial fitting was used:

$$
a(T)=p_{2} T^{2}+p_{1} T+p_{0}
$$

where $a(T)$ represents a parameter used in $\mathrm{P}-\mathrm{V} / \mathrm{Q}-\mathrm{V}$ curve fitting of either ramp-down or ramp-up processes at temperature $T$ (between $80^{\circ} \mathrm{F}$ and $115^{\circ} \mathrm{F}$ ). The polynomial fitting parameters are listed in Table B.2 in Appendix B.

\subsubsection{BPA Data Sets}

As can be seen in Table B.2, the number of temperatures, under which different AC compressors were tested, differed. Although ramp-down data were available at multiple temperatures for most compressors, rampup data were available at fewer temperatures. Therefore, temperature interpolation was only conducted when data were available from at least three testing temperatures. The temperature interpolation starts with a second order polynomial fitting on each curve-fitting parameter based on the optimal curve-fitting parameter values at the testing temperatures where $a(T)$ represents a parameter used in P-V/Q-V curve fitting of either ramp-down or ramp-up processes at temperature $T$. Then the curve-fitting parameters at any temperature within the temperature range being tested are calculated from the polynomial fitting parameters and are subsequently used to simulate the $\mathrm{P}-\mathrm{V} / \mathrm{Q}-\mathrm{V}$ curves at that temperature.

Because the AC Payne 3-Ton Scroll PA12NA036 has data at three common temperatures for both rampdown and ramp-up processes, it was used to demonstrate the temperature interpolation of curve-fitting parameters and the subsequent simulation of $\mathrm{P}-\mathrm{V} / \mathrm{Q}-\mathrm{V}$ curves at any temperature in the testing temperature range. The polynomial fitting parameters of this $\mathrm{AC}$ are tabulated in Table A.4 in Appendix $\mathrm{A}$ and the interpolated P-V/Q-V time series at temperatures between $80^{\circ} \mathrm{F}$ to $115^{\circ} \mathrm{F}$ are shown below in Figure 7 .

For other AC compressors, the temperature interpolation was still conducted whenever data from at least three temperatures are available for either ramp-down or ramp-up process and simulated $\mathrm{P}-\mathrm{V} / \mathrm{Q}-\mathrm{V}$ curves are shown in Figure A.2 in Appendix A, but the polynomial fitting parameters are not listed. 


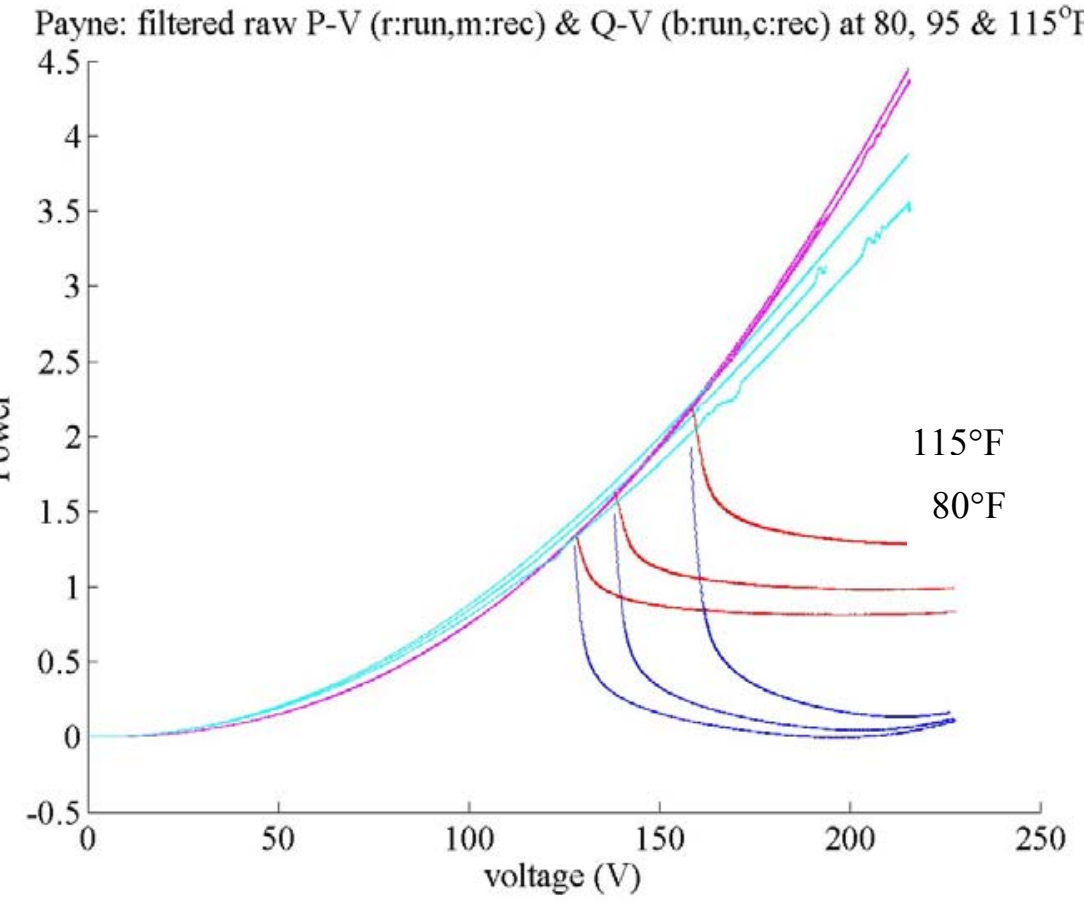

(a)

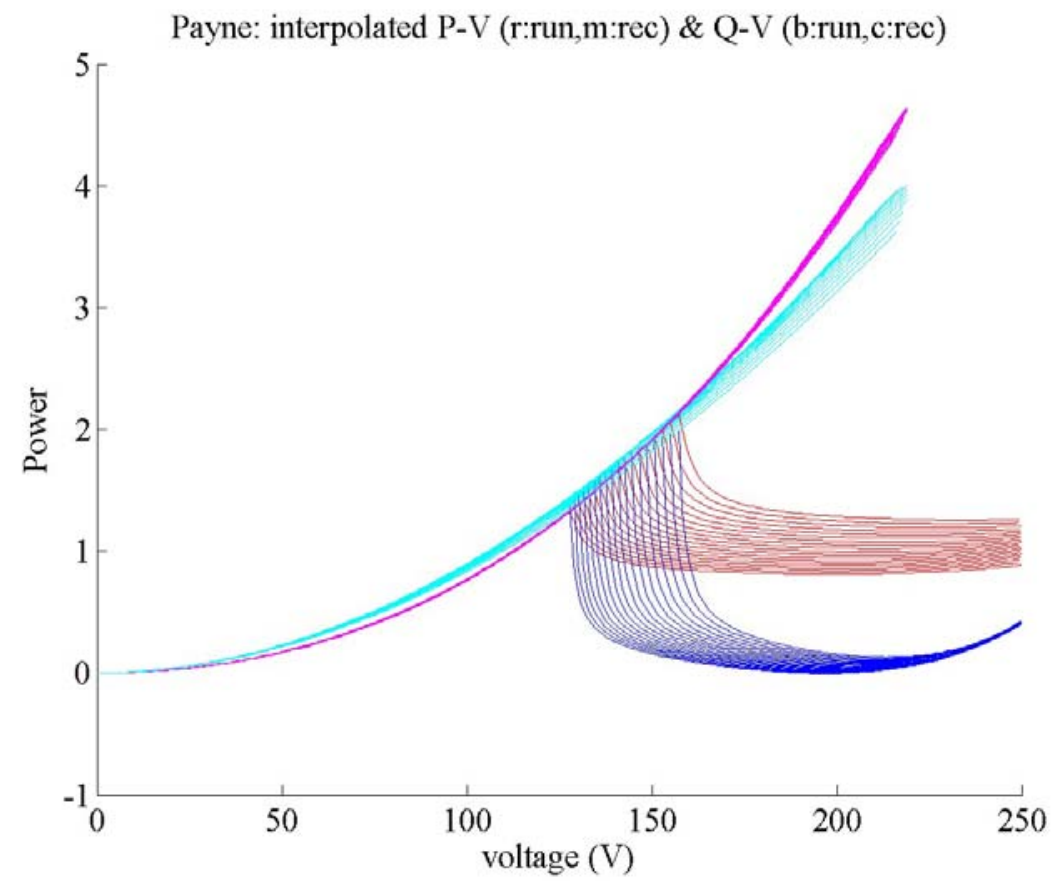

(b)

Figure 7. Normalized Filtered P-V/Q-V at Three Temperatures (left) and Simulated P-V/Q-V (right) at Several Temperatures Between $80^{\circ} \mathrm{F}$ and $115^{\circ} \mathrm{F}$ for the Payne 3-Ton Scroll PA12NA036 (red: ramp-down $\mathrm{P}-\mathrm{V}$, magenta: ramp-up $\mathrm{P}-\mathrm{V}$, blue: ramp-down $\mathrm{Q}-\mathrm{V}$ and cyan: ramp-up Q-V) 


\subsection{Discussion of Results}

The components of a performance model representing an individual SPAC unit are described and illustrated, and the aggregation of individual models are discussed in the following sections.

\subsection{Individual Compressor Models}

Figure 8 and Figure 9 show the running and stalling curves derived from the voltage ramp-down and rampup cases when the ambient temperature was $100^{\circ} \mathrm{F}$. The black bars in Figure 8 shows the voltage range of the compressor stalling voltages.

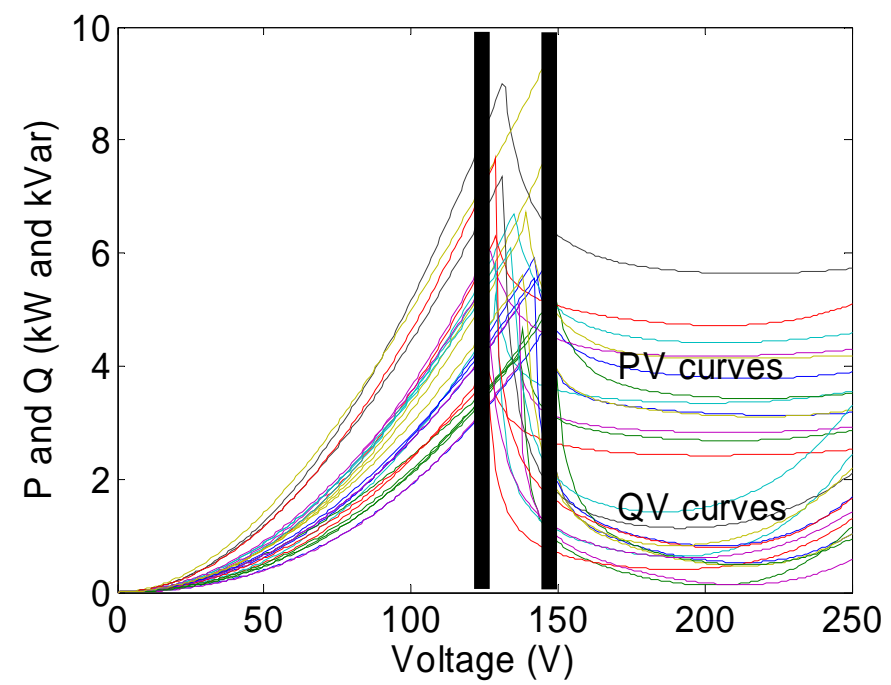

(a) P-V and Q-V curves

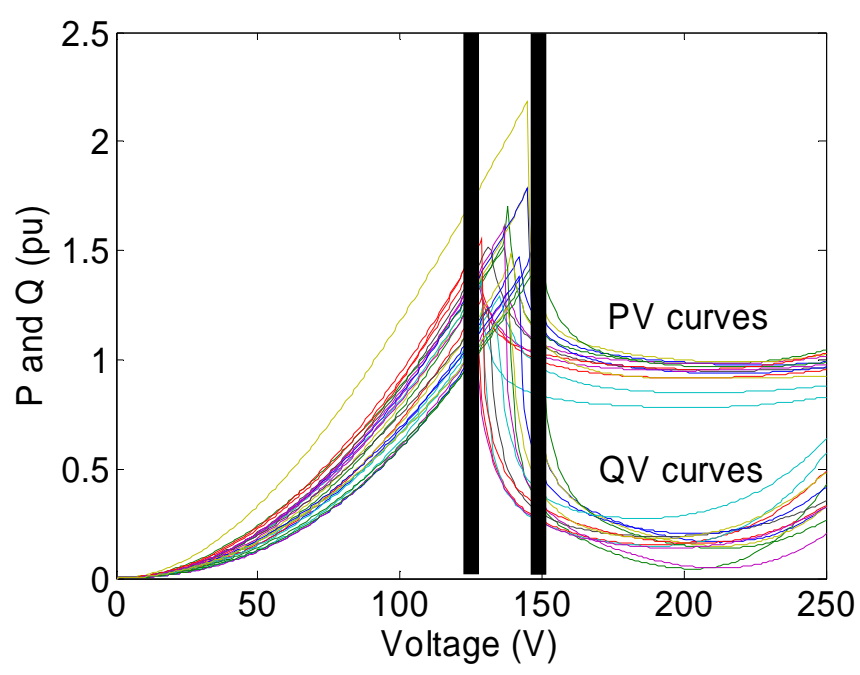

(b) Normalized P-V and Q-V curves

Figure 8. The P-V and Q-V Curves of 11 Tested Compressors Obtained from Voltage Ramp-Down Tests 


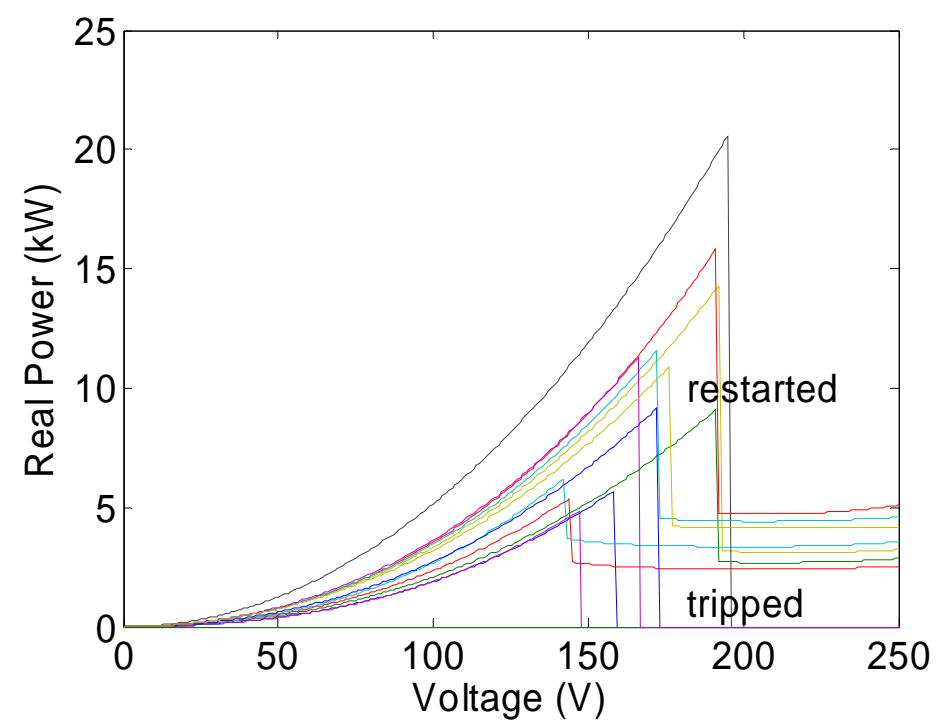

(a) P-V and Q-V curves

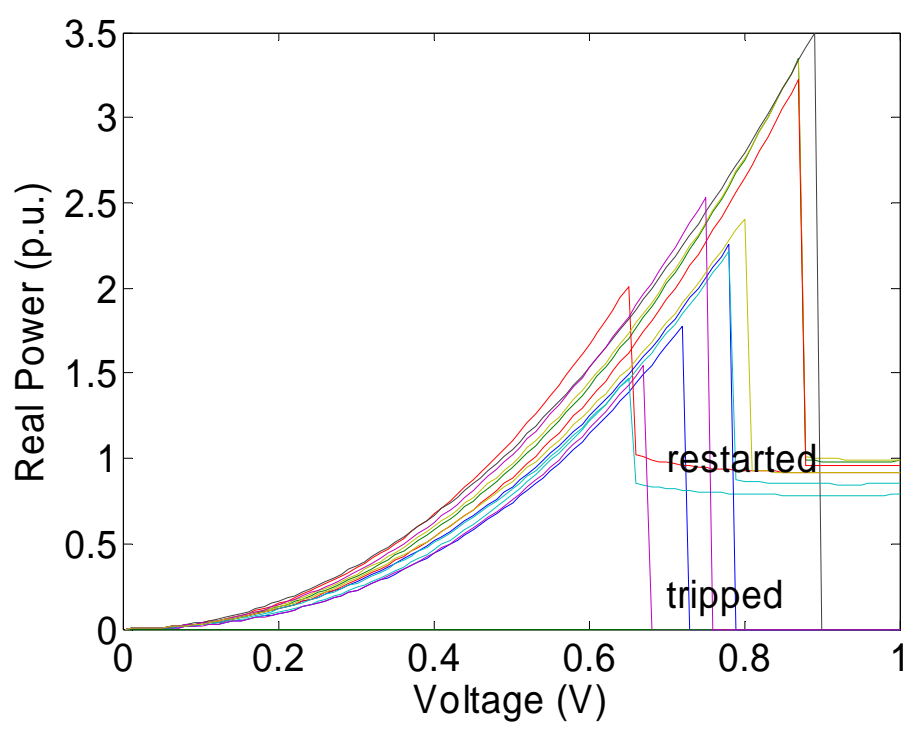

(b) Normalized P-V and Q-V curves

Figure 9. The P-V and Q-V Curves of 11 Tested Compressors Obtained from Voltage Ramp-Up Tests

There are few observations:

- Stalling voltages: As shown in Table 6, the stalling voltages range from $126 \mathrm{~V}$ to $149 \mathrm{~V}$. As shown in Figure 10 , the stalling voltage increases proportionally $\left(2\right.$ to $3 \mathrm{~V} /{ }^{\circ} \mathrm{F}$ ) when the ambient temperature increases. The band width of the stalling voltages is approximately $25 \mathrm{~V}$ for all of the compressors tested. As shown in Figure 11 (Kosterev 2007), the stalling voltage is also related with fault duration. Therefore, the stalling voltages range from 0.5 to 0.6 p.u., depending on the fault duration and ambient temperature.

- Recovery voltage: As shown in Figure 9, some compressor motors were tripped by thermal relay before the voltage recovered to full voltage. Instead of restarting, AC4 tested by SCE rotated backwards. The 
motor restart depends on the pressure equalization process of the compressor. Usually, it takes minutes for the pressure to equalize. Some of the motors may be tripped off line because the thermal relay reacts with the increased temperature in the motor winding. To be conservative in modeling, one can assume that all the compressor motors will not restart once they stall.

Table 6. The Stall and Recover Voltages of the Tested Compressors

\begin{tabular}{|c|c|c|l|}
\hline AC Name & Vstall (V) & \multicolumn{2}{|c|}{ Vrecover (V) } \\
\hline Carrier 3-Ton Recip 38TKB036 & 146 & 159 & tripped \\
\hline Payne 3-Ton Scroll PA12NA036 & 138 & 192 & restarted \\
\hline Trane 3-Ton Recip 2TTB0036A & 126 & 145 & restarted \\
\hline York 3.5-Ton Recip H4DB042S06 & 129 & 143 & restarted \\
\hline York 4-Ton Scroll H5DB048S06 & 138 & 148 & tripped \\
\hline York 3-Ton Recip H4DB036S06 & 146 & 193 & restarted \\
\hline AC10-Carrier 5-Ton Scroll & 132 & 196 & tripped \\
\hline AC3-Rheem 3-Ton Scroll & 143 & 173 & tripped \\
\hline AC4-Carrier 3-Ton Scroll & 149 & 90 & rotate backwards \\
\hline AC5-Coleman 4-Ton Scroll & 130 & 191 & restarted \\
\hline AC6-Rheem 4-Ton Scroll & 135 & 172 & restarted \\
\hline AC7-Carrier 4-Ton Scroll & 126 & 166 & tripped \\
\hline AC8-Goodman 4-Ton Recip & 138 & 177 & restarted \\
\hline
\end{tabular}

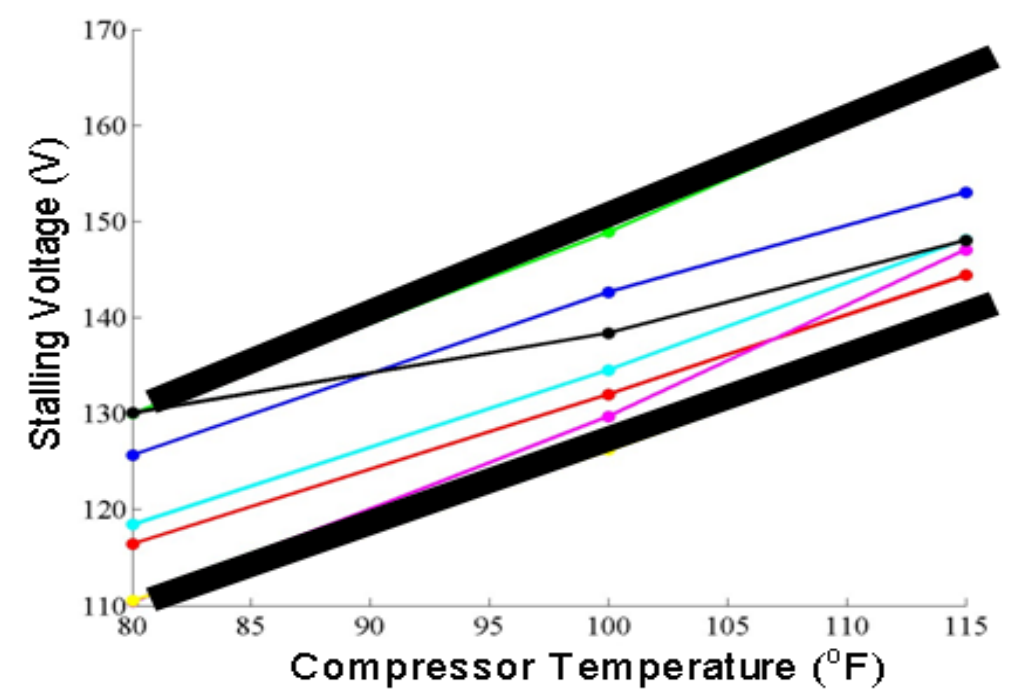

Figure 10. The Impact of Ambient Temperature on Compressor Stalling Voltage 


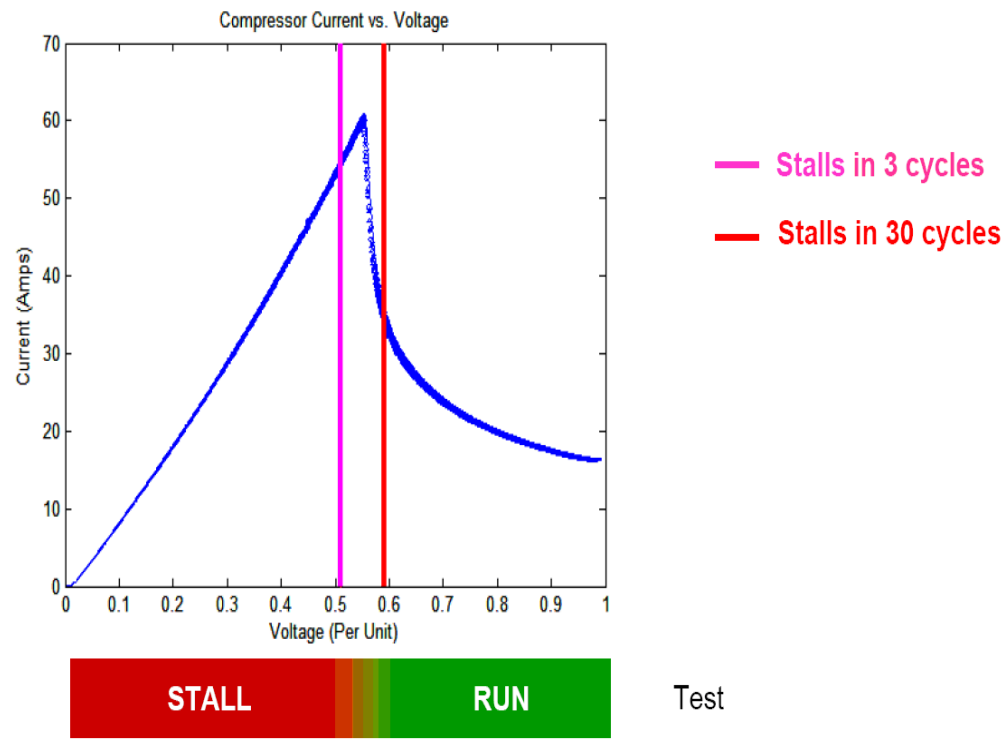

Figure 11. The Impact of Voltage Sag Duration on Compressor Stalling Voltage (Kosterev 2007)

- Running curves: There is more than one way to represent running curves. One can choose to represent a running curve by one- or two-segment curves. For the purposes of this effort, PNNL used one continuous function to represent the running curve and BPA used a two-segment representation. Both worked well in the simulation. The key issue is that if one wants to get a more accurate representation for voltage oscillation as shown in Figure 12, a more sophisticated representation of real power will be needed. Otherwise, the compressor real power can be considered to be constant power load when running above stalling voltage. The reactive power changes more dramatically ( 0.2 to 0.4 p.u.) compared with the real power variations. Depending on the purpose of the simulation, one can represent it using polynomial functions as defined by Kosterev (2007) or as described in Section 2.3.

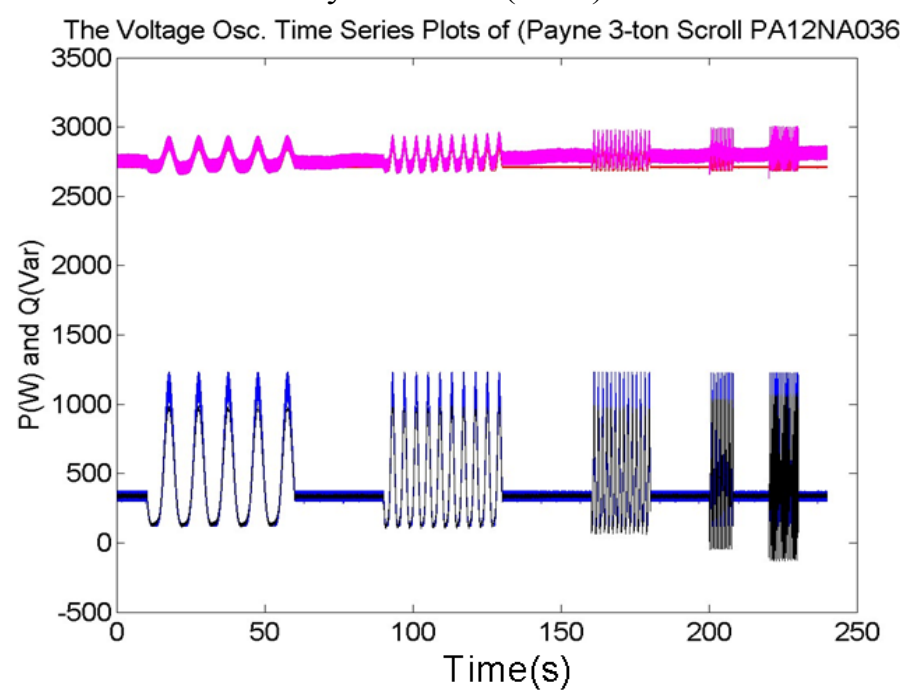

Figure 12. An Example of Validating the Voltage Oscillation Case. The curves obtained by Optimal CurveFitting Parameters (red: P and blue: Q); the curves obtained from measurement (magenta: P and black: Q) 
- Stalling curves: The representation of the stalling curve is straight forward; one can either use

$$
\begin{aligned}
& P_{\text {stall }}=K_{P} V^{2} \\
& Q_{\text {stall }}=K_{q} V^{2}
\end{aligned}
$$

or to be more precise use

$$
\begin{aligned}
& P_{\text {stall }}=K_{P 1} V^{3}+K_{P 2} V^{2} \\
& Q_{\text {stall }}=K_{q 1} V^{3}+K_{q 2} V^{2}
\end{aligned}
$$

As shown in Figure 7, the stalling curve is not sensitive to the ambient temperature. Once the motor stalls, the motor will be treated as a $\mathrm{Z}$ type load.

- Frequency dependency: As shown in Figure 13, the motor real power didn't vary much when frequency varied from $57 \mathrm{~Hz}$ to $63 \mathrm{~Hz}$. The reactive power variation was around 100 Var per $1 \mathrm{~Hz}$ change.

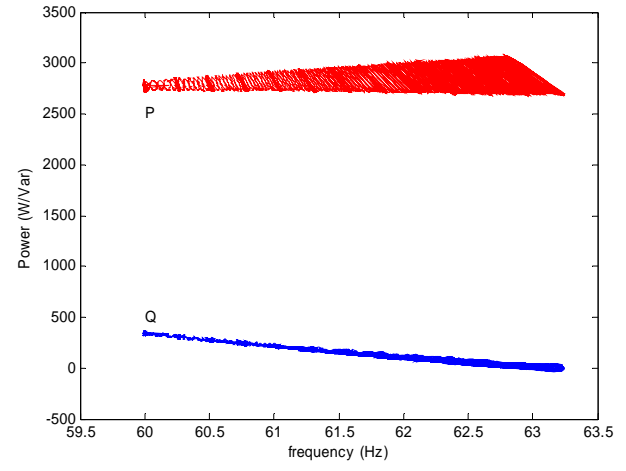

(a)

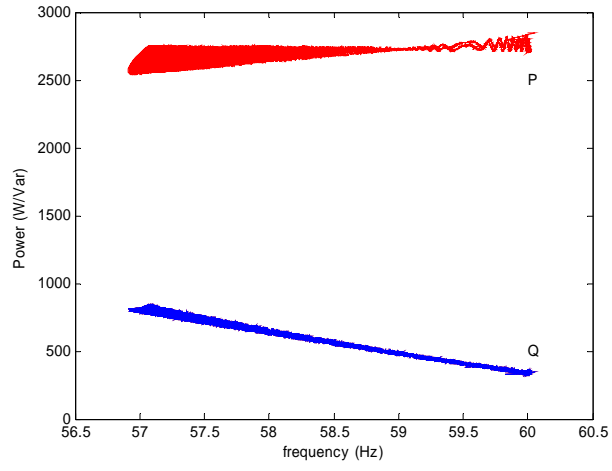

(b)

Figure 13. Frequency Dependency Derived from Frequency Ramp-Up Case

- The thermal relay model: A second-order piece-wise fit was applied to fit the tripping time $T_{\text {trip }}$ to the tripping current $\mathrm{i}$. The formula is

$$
T_{\text {trip }}=a_{2} i^{2}+a_{1} i+a_{0}
$$

The curve-fitting results are listed in Table 7. The measurement data and the curve-fitting results are shown in Figure 14.

Table 7. The Curve-Fitting Parameters for Thermal Relays

\begin{tabular}{|l|r|r|r|l|}
\hline \hline & \multicolumn{1}{|l|}{ a2 } & \multicolumn{1}{l|}{ a1 } & \multicolumn{1}{l|}{ a0 } & $\begin{array}{l}\text { Current } \\
\text { Range }\end{array}$ \\
\hline Segment 1 & 0 & 0 & 2.27 & $\mathrm{i}>106$ \\
\hline Segment 2 & 0.00695 & -1.44 & 77 & $106>\mathrm{i}>65$ \\
\hline Segment 3 & 0.2 & -27.1 & 929 & $65>\mathrm{i}>55$ \\
\hline \hline
\end{tabular}




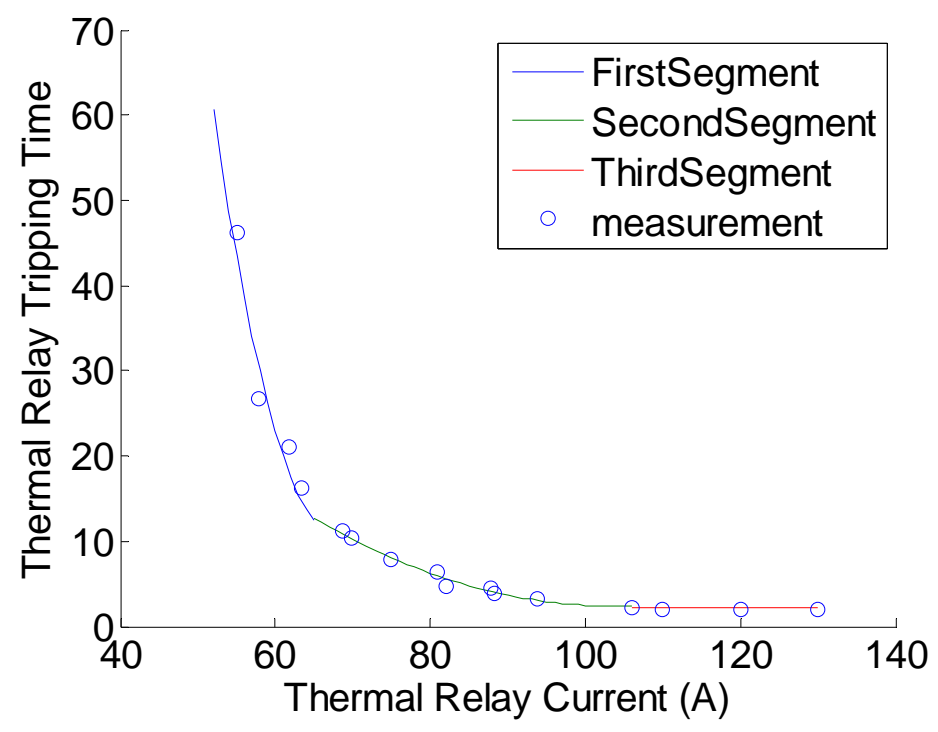

Figure 14. Thermal Relay Testing Results

- A complete parameter set of all tested compressor motors is shown in Table 8 through Table 11.

Table 8. The Normalized Running P Curve Parameters

\begin{tabular}{|l|c|c|c|c|c|}
\hline \multicolumn{1}{|c|}{ AC Name } & b(0)_P(run) & b(1)_P(run) & b(2)_P(run) & b(3)_P(run) & b(4)_P(run) \\
\hline Carrier 3-Ton Recip 38TKB036 & 0.65 & 1.00 & 0.01 & -0.16 & 0.99 \\
\hline Payne 3-Ton Scroll PA12NA036 & 0.61 & 0.99 & 0.01 & -0.17 & 1.69 \\
\hline Trane 3-Ton Recip 2TTB0036A & 0.54 & 0.83 & 0.02 & 0.07 & 0.42 \\
\hline York 3.5-Ton Recip H4DB042S06 & 0.57 & 0.77 & 0.01 & -0.06 & 0.80 \\
\hline York 4-TonScroll H5DB048S06 & 0.60 & 0.96 & 0.01 & -0.05 & 0.78 \\
\hline York 3-Ton Recip H4DB036S06 & 0.65 & 1.03 & 0.01 & -0.26 & 1.94 \\
\hline AC10-Carrier 5-Ton Scroll & 0.56 & 0.87 & 0.02 & 0.05 & 0.28 \\
\hline AC3-Rheem 3-Ton Scroll & 0.62 & 0.90 & 0.02 & -0.06 & 0.91 \\
\hline AC4-Carrier 3-Ton Scroll & 0.64 & 0.88 & 0.02 & 0.06 & 0.70 \\
\hline AC5-Coleman 4-Ton Scroll & 0.57 & 1.01 & 0.01 & -0.26 & 1.54 \\
\hline AC6-Rheem 4-Ton Scroll & 0.57 & 0.73 & 0.03 & 0.11 & 0.40 \\
\hline AC7-Carrier 4-Ton Scroll & 0.53 & 0.82 & 0.03 & 0.14 & 0.18 \\
\hline AC8-Goodman 4-Ton Recip & 0.59 & 0.73 & 0.03 & 0.30 & -0.27 \\
\hline
\end{tabular}


Table 9. The Normalized Running Q Curve Parameters

\begin{tabular}{|c|c|c|c|c|c|}
\hline AC Name & b(0)_Q(run) & b(1)_Q(run) & $\mathbf{b}(2) \_Q($ run $)$ & b(3)_Q(run) & b(4)_Q(run) \\
\hline Carrier 3-Ton Recip 38TKB036 & 0.65 & 0.30 & 0.01 & -0.72 & 6.65 \\
\hline Payne 3-Ton Scroll PA12NA036 & 0.62 & 0.21 & 0.01 & -0.92 & 9.39 \\
\hline Trane 3-Ton Recip 2TTB0036A & 0.56 & 0.15 & 0.02 & -0.29 & 4.36 \\
\hline York 3.5-Ton Recip H4DB042S06 & 0.58 & 0.20 & 0.01 & -0.45 & 6.25 \\
\hline York 4-Ton Scroll H5DB048S06 & 0.60 & 0.20 & 0.02 & -0.76 & 4.76 \\
\hline York 3-Ton Recip H4DB036S06 & 0.65 & 0.29 & 0.01 & -0.78 & 7.29 \\
\hline AC10 Carrier 5-Ton Scroll & 0.58 & 0.11 & 0.02 & 0.00 & 2.16 \\
\hline AC3-Rheem 3-Ton Scroll & 0.63 & 0.24 & 0.01 & -0.41 & 5.48 \\
\hline AC4-Carrier 3-Ton Scroll & 0.66 & 0.17 & 0.02 & -0.44 & 5.34 \\
\hline AC5-Coleman 4-Ton Scroll & 0.57 & 0.25 & 0.02 & -0.52 & 3.37 \\
\hline AC6-Rheem 4-Ton Scroll & 0.59 & 0.18 & 0.02 & 0.01 & 4.76 \\
\hline AC7-Carrier 4-Ton Scroll & 0.55 & 0.10 & 0.02 & -0.18 & 2.51 \\
\hline AC8-Goodman 4-Ton Recip & 0.61 & 0.04 & 0.03 & 0.09 & 4.49 \\
\hline
\end{tabular}

Table 10. Normalized Stalling Curve Parameters

\begin{tabular}{|l|c|c|c|c|}
\hline \multicolumn{1}{|c|}{ AC Name } & $\mathbf{k}(\mathbf{1}) \_\mathbf{P}($ stall) & $\mathbf{k}(\mathbf{2}) \_\mathbf{P}($ stall) & $\mathbf{k}(\mathbf{1}) \_\mathbf{Q ( s t a l l )}$ & $\mathbf{k}(\mathbf{2})$ Q(stall) \\
\hline Carrier 3-Ton Recip 38TKB036 & 2.13 & 1.90 & 0.23 & 3.95 \\
\hline Payne 3-Ton Scroll PA12NA036 & 1.71 & 2.93 & -1.96 & 5.13 \\
\hline Trane 3-Ton Recip 2TTB0036A & 2.20 & 3.33 & -0.10 & 4.41 \\
\hline York 3.5-Ton Recip H4DB042S06 & 2.33 & 1.98 & 0.12 & 3.89 \\
\hline York 4-Ton Scroll H5DB048S06 & 2.40 & 1.83 & 0.28 & 3.99 \\
\hline York 3-Ton Recip H4DB036S06 & 1.42 & 3.18 & -3.24 & 7.16 \\
\hline AC10-Carrier 5-Ton Scroll & 0.49 & 3.98 & -0.93 & 4.04 \\
\hline AC3-Rheem 3-Ton Scroll & 1.30 & 2.69 & -0.11 & 3.39 \\
\hline AC4-Carrier 3-Ton Scroll & 1.68 & 2.10 & 0.87 & 2.55 \\
\hline AC5-Coleman 4-Ton Scroll & 1.89 & 2.61 & -0.14 & 4.61 \\
\hline AC6-Rheem 4-Ton Scroll & 1.29 & 2.64 & -0.21 & 3.29 \\
\hline AC7-Carrier 4-Ton Scroll & 1.70 & 3.24 & -0.38 & 4.08 \\
\hline AC8-Goodman 4-Ton Recip & 0.94 & 3.01 & -0.27 & 3.32 \\
\hline
\end{tabular}


Table 11. Normalized Stalling Voltage and Recover Voltage

\begin{tabular}{|l|c|c|l|}
\hline \multicolumn{1}{|c|}{ AC Name } & Vstall (V) & \multicolumn{2}{c|}{ Vrecover (V) } \\
\hline Carrier 3-Ton Recip 38TKB036 & 0.66 & 0.72 & tripped \\
\hline Payne 3-Ton Scroll PA12NA036 & 0.63 & 0.87 & restarted \\
\hline Trane 3-Ton Recip 2TTB0036A & 0.57 & 0.66 & restarted \\
\hline York 3.5-Ton Recip H4DB042S06 & 0.59 & 0.65 & restarted \\
\hline York 4-Ton Scroll H5DB048S06 & 0.63 & 0.67 & tripped \\
\hline York 3-Ton Recip H4DB036S06 & 0.66 & 0.88 & restarted \\
\hline AC10-Carrier 5-Ton Scroll & 0.60 & 0.89 & tripped \\
\hline AC3-Rheem 3-Ton Scroll & 0.65 & 0.79 & tripped \\
\hline AC4-Carrier 3-Ton Scroll & 0.68 & 0.41 & rotate backwards \\
\hline AC5-Coleman 4-Ton Scroll & 0.59 & 0.87 & restarted \\
\hline AC6-Rheem 4-Ton Scroll & 0.61 & 0.78 & restarted \\
\hline AC7-Carrier 4-Ton Scroll & 0.57 & 0.76 & tripped \\
\hline AC8-Goodman 4-Ton Recip & 0.63 & 0.80 & restarted \\
\hline
\end{tabular}

\subsection{Aggregated Performance Model}

The green lines in Figure 15(a) and (b) illustrate a weighted aggregated P-V and P-Q curve for all of the individual motor $\mathrm{P}-\mathrm{V}$ and $\mathrm{P}-\mathrm{Q}$ curves.

There are several observations:

- Stalling voltage: When using an aggregated stalling voltage to represent the stalling threshold of a group of motors with different stalling voltages, an uncertainty is introduced. Therefore, knowing how to select the stalling voltage for an aggregated model is crucial. In reality, if one motor stalls, it draws three to seven times its normal current. The increased current then leads to further voltage depression. Other motors with slightly lower stalling voltages then stall because of the further drop in voltage. Because of this cascade stalling phenomenon, we recommend the aggregated stalling voltage to be the highest stalling voltage instead of the weighted average stalling voltage.

- Recovery voltage: Very few single-phase AC motors can restart in a few seconds once they stall. The high gas pressure in the compression chamber makes the load torque far greater than the starting torque of the compressor. The stalled motors are eventually taken offline by their thermal relays and will remain offline unless they are reset.

- The running curve and the stalling curve: The aggregated running and stalling curves show a fair agreement between the individual $\mathrm{P}-\mathrm{V}$ and $\mathrm{P}-\mathrm{Q}$ curves and the aggregated $\mathrm{P}-\mathrm{V}$ and $\mathrm{P}-\mathrm{Q}$ curves. Therefore, it is reasonable to use weighted average P-V and P-Q running and stalling curves to represent the aggregated behavior of the single-phase AC motors.

- Thermal relay model: As shown in Figure 16, when aggregated together, a percentage tripping curve can be applied to represent the uncertainty and diversity of the individual motor tripping time caused by the different current and voltage seen at each motor circuit. 


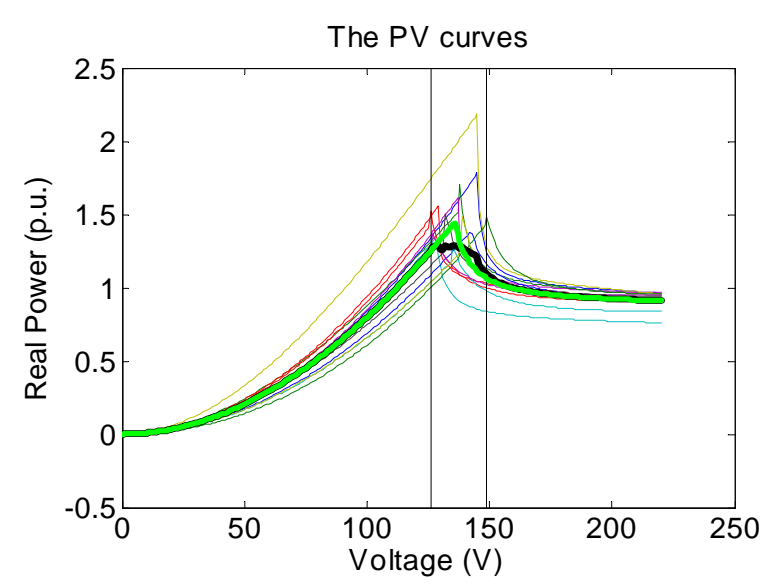

(a)

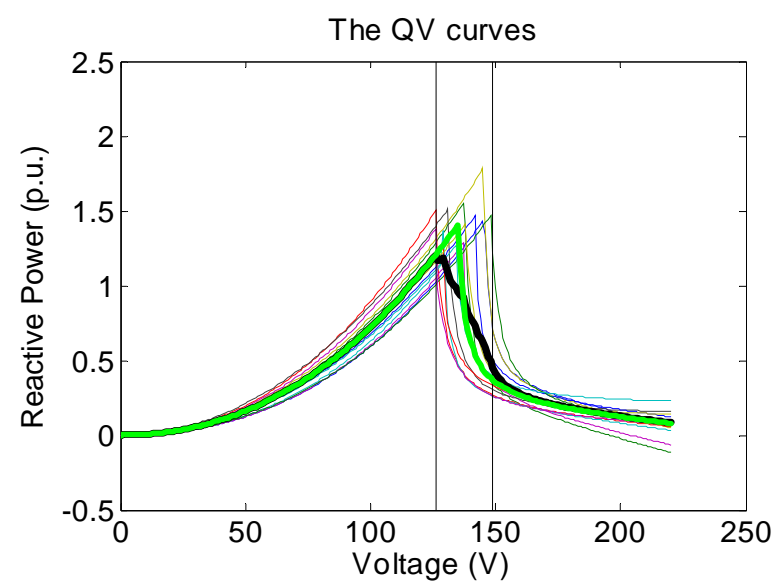

(b)

Figure 15. Aggregate $\mathrm{P}-\mathrm{V}$ and $\mathrm{Q}-\mathrm{V}$ curves. (Green: Modeling results using one big motor (parameter calculated by weighted average method. Black: Detailed aggregation results of each individual motor.)

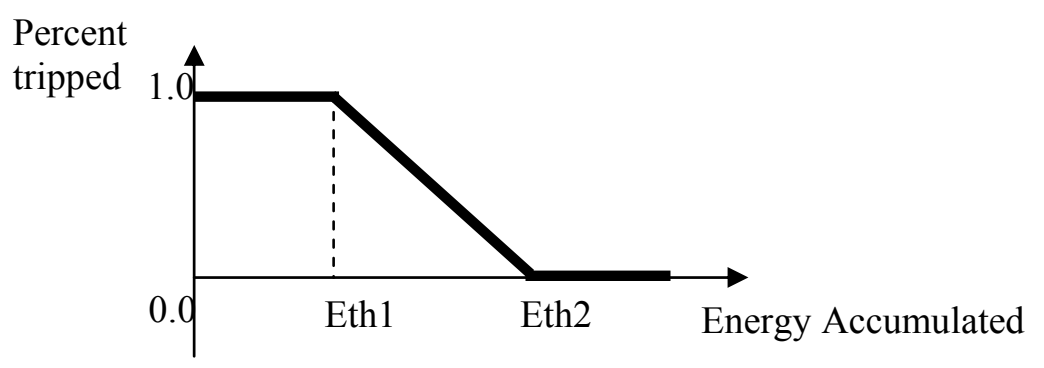

Figure 16. Aggregate Thermal Tripping Curves 


\subsection{References}

Yinger R, R Bravo, and D Martinez. 2006 Air Conditioner Stalling Effects Study/Air Conditioner Testing Procedures. Southern California Edison, Rosemead, California.

Bravo, R, R Yinger, and L Gaillac. 2006. Conditioner Stalling Unit Level Solutions Test Report. Southern California Edison, Rosemead, California.

Kosterev, D. 2007. LMTF 2007-02 - AC Unit Model Specifications. LMTF document, Bonneville Power Administration, Vancouver, Washington.

Lu N and Z Huang. 2008. WECC Air Conditioner Load Model Performance Model Specifications. PNNL16355, Pacific Northwest National Laboratory, Richland, Washington.

Lu N and HA Qiao. 2007. Composite Load Model Evaluation. PNNL-16916, Pacific Northwest National Laboratory, Richland, Washington.

Lu N, B Yang and Z Huang. 2008a. Evaluation of Southern California Edison Air-Conditioner Stalling Solutions. PNNL-17686, Pacific Northwest National Laboratory, Richland, Washington.

Lu N, B Yang, Z Huang, R Bravo, and D Kosterev. 2008b. The System Impact of Air Conditioner Undervoltage Protection Schemes. PNNL-61885, Pacific Northwest National Laboratory, Richland, Washngton. 


\section{Appendix A}

\section{Curve-Fitting Plots for BPA-Tested Motors}



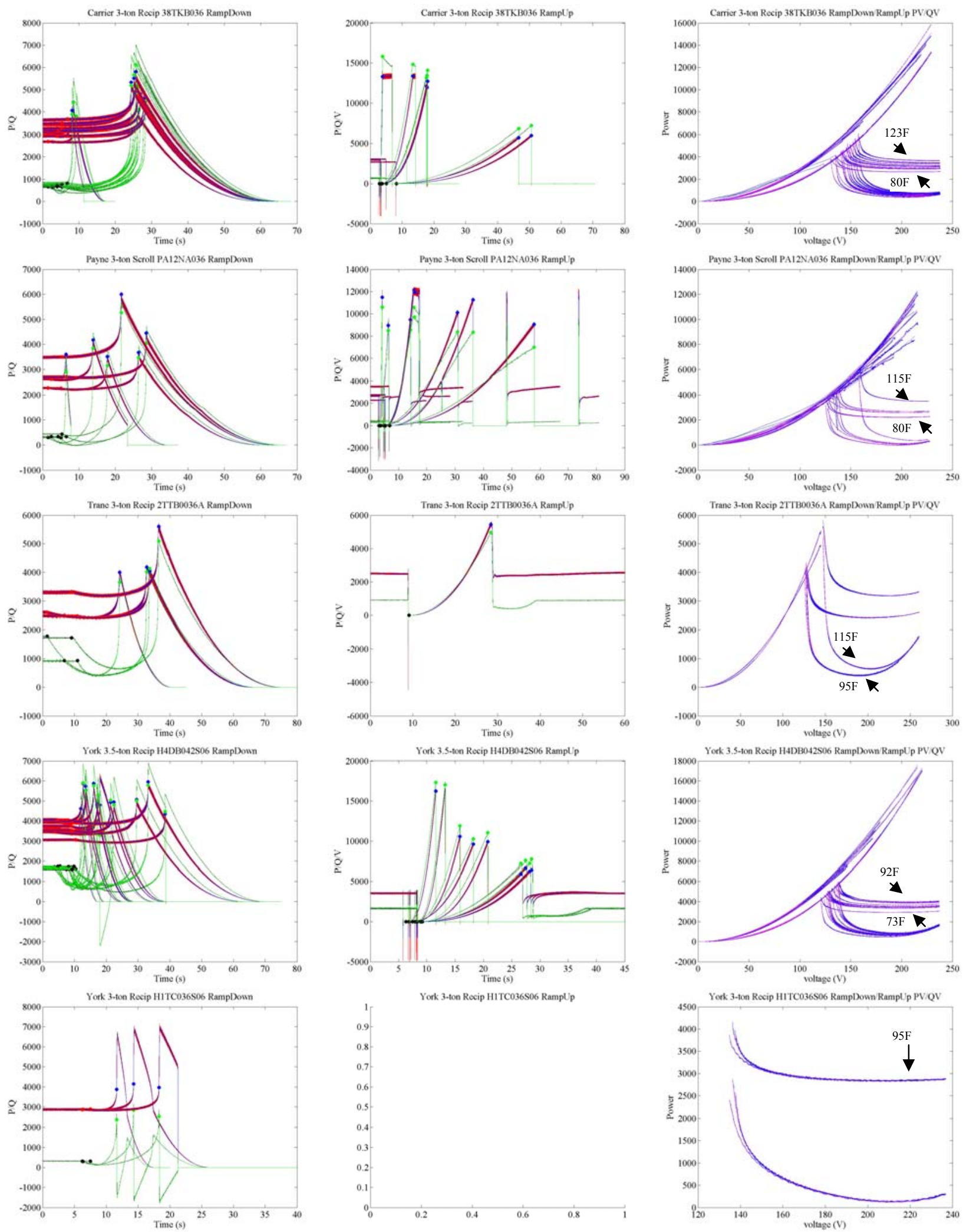

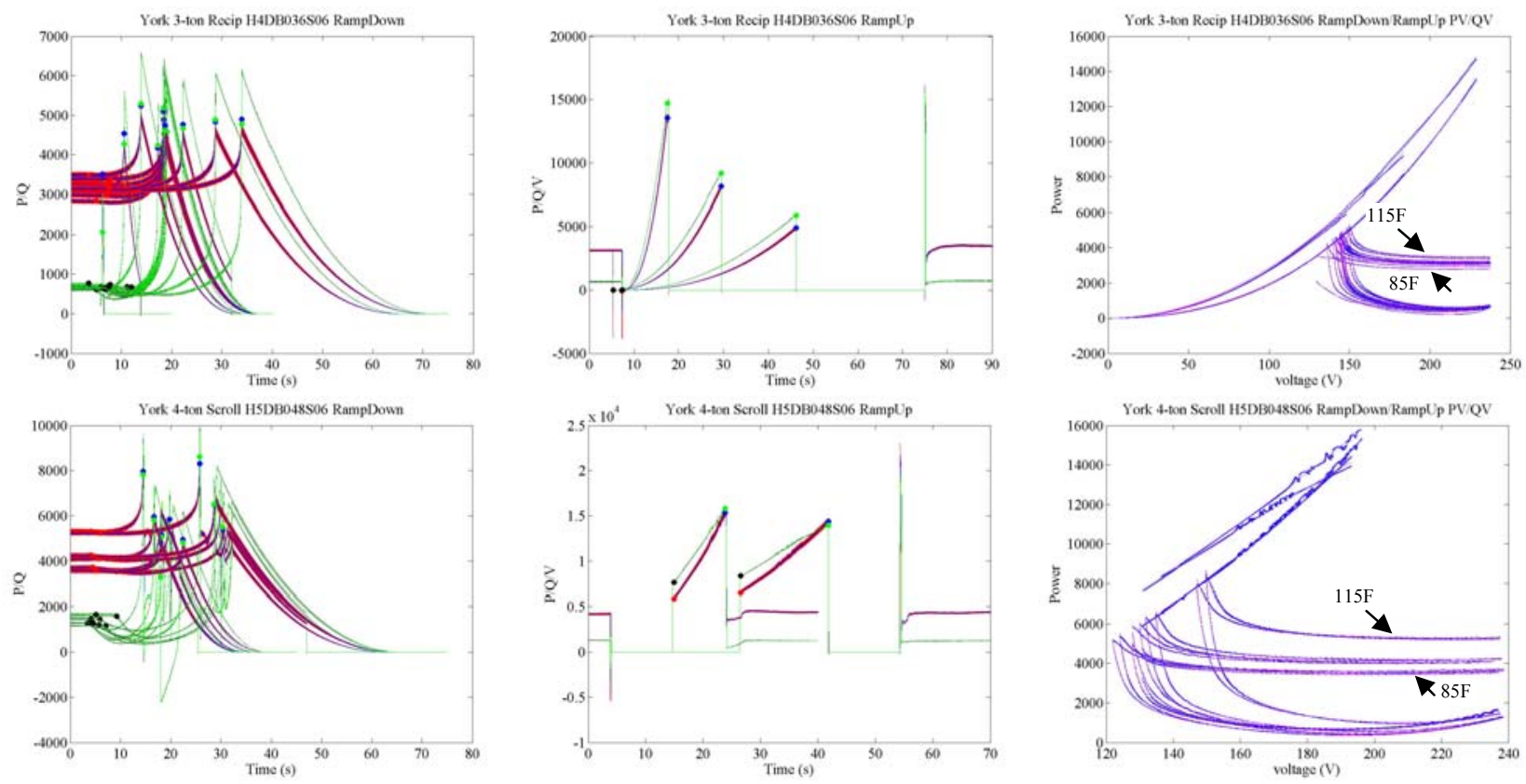

Figure A.1. Original Test Results (black) and Filtered P (red)/Q (green) at Ramp-Down (left) and the P-V/Q-V Curves (right) of all Files (see Table 1) for the Seven Air-Conditioners (ACs) Used (from top to bottom, AC name is displayed in the plot title) 

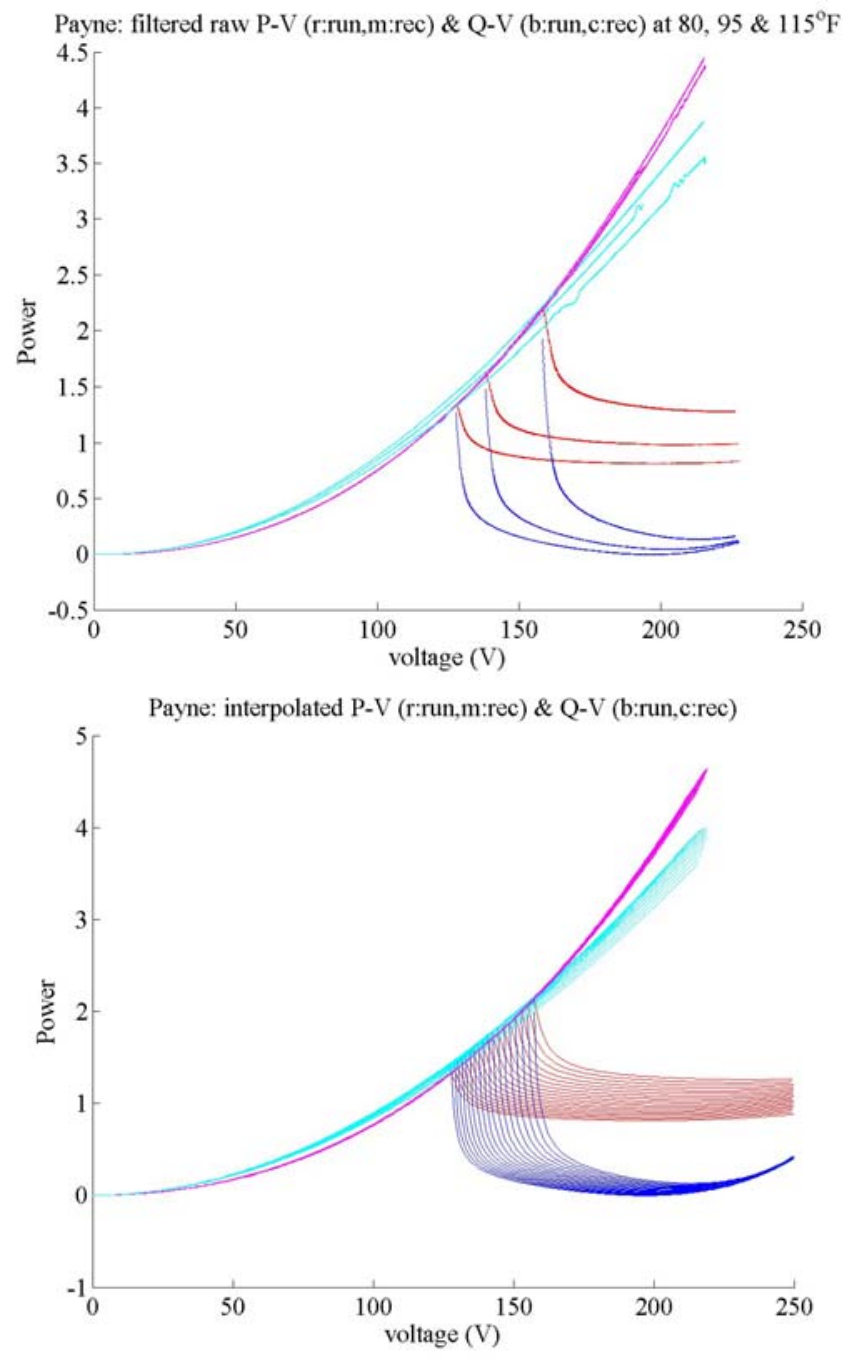

Figure A.2. Normalized Filtered P-V/Q-V at Three Temperatures (left) and Simulated P-V/Q-V (right) at Several Temperatures Between $80^{\circ} \mathrm{F}$ and $115^{\circ} \mathrm{F}$ for the Payne 3-Ton Scroll PA12NA036 (red: rampdown $\mathrm{P}-\mathrm{V}$; magenta: ramp-up P-V; blue: ramp-down Q-V; cyan: ramp-up Q-V) 

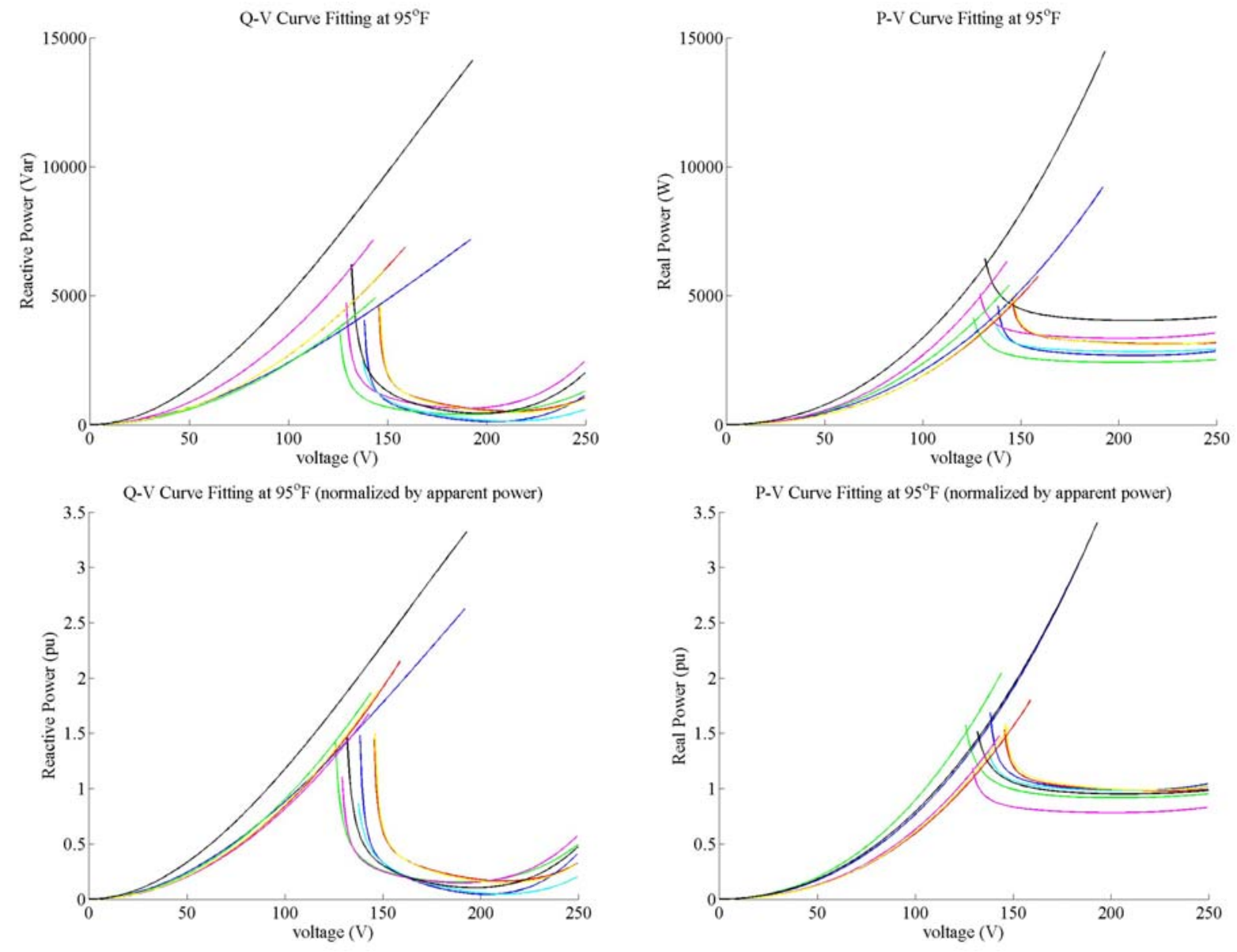

—: Carrier 3-ton Recip 38TKB036

-: Payne 3-ton Scroll PA12NA036

- Trane 3-ton Recip 2TTB0036A

—: York 3.5-ton Recip H4DB042S06

—: York 3-ton Recip H1TC036S06

—: York 4-ton Scroll H5DB048S06

Figure A.3. Fitted Curves for All Seven AC Motors; $95^{\circ} \mathrm{F}$ Based on Raw Filtered Data (top) and Normalized Filtered Data (bottom) 

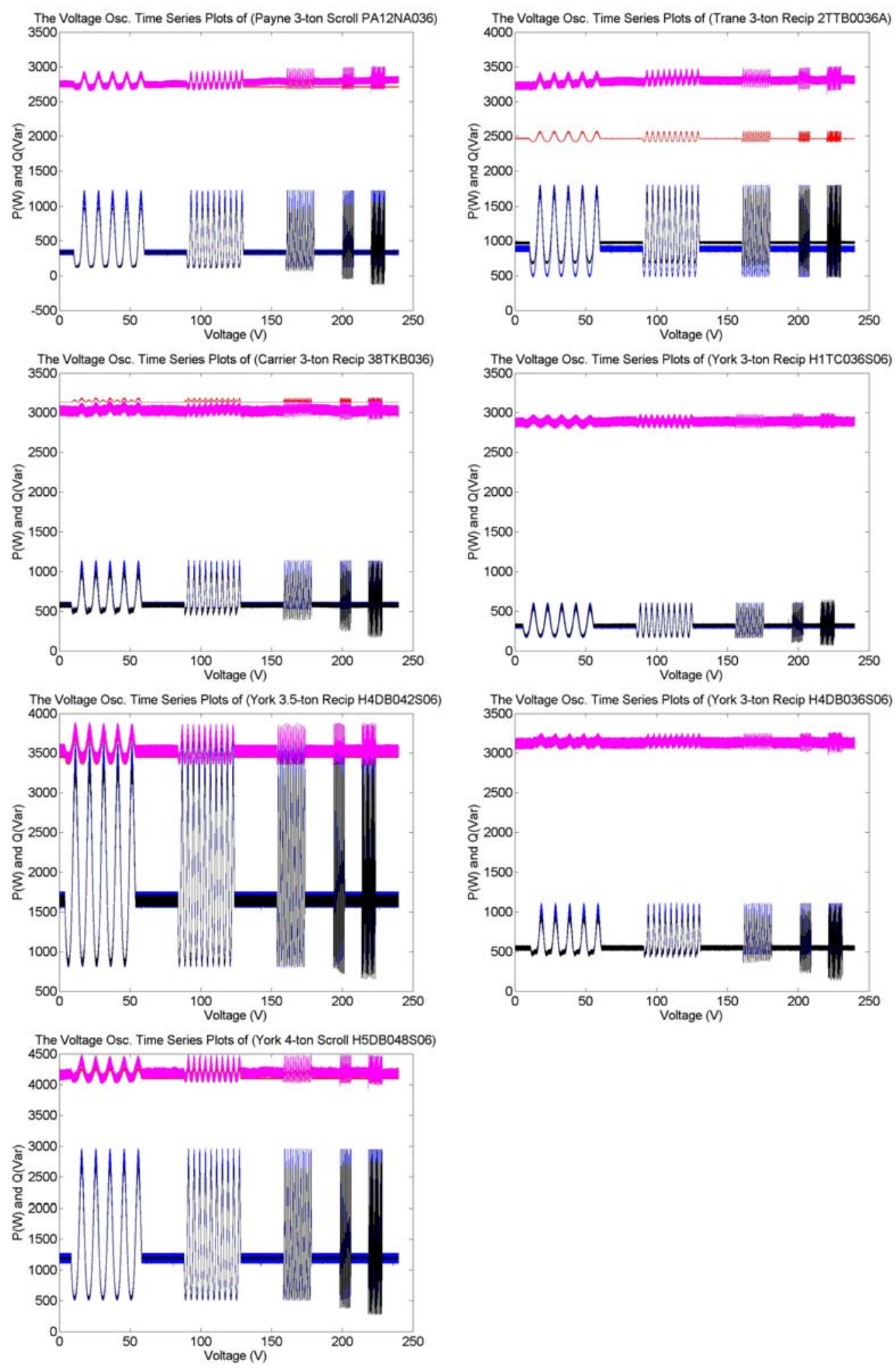

Figure A.4. Comparison of the Reconstructed P/Q Voltage-Oscillation Time Series Using the Optimal Curve-Fitting Parameters (red: P and blue: Q) with the Test Data Measured (magenta: P and black Q) 
Appendix B

Curve-Fitting Plots and Tables for SCE-Tested Motors 

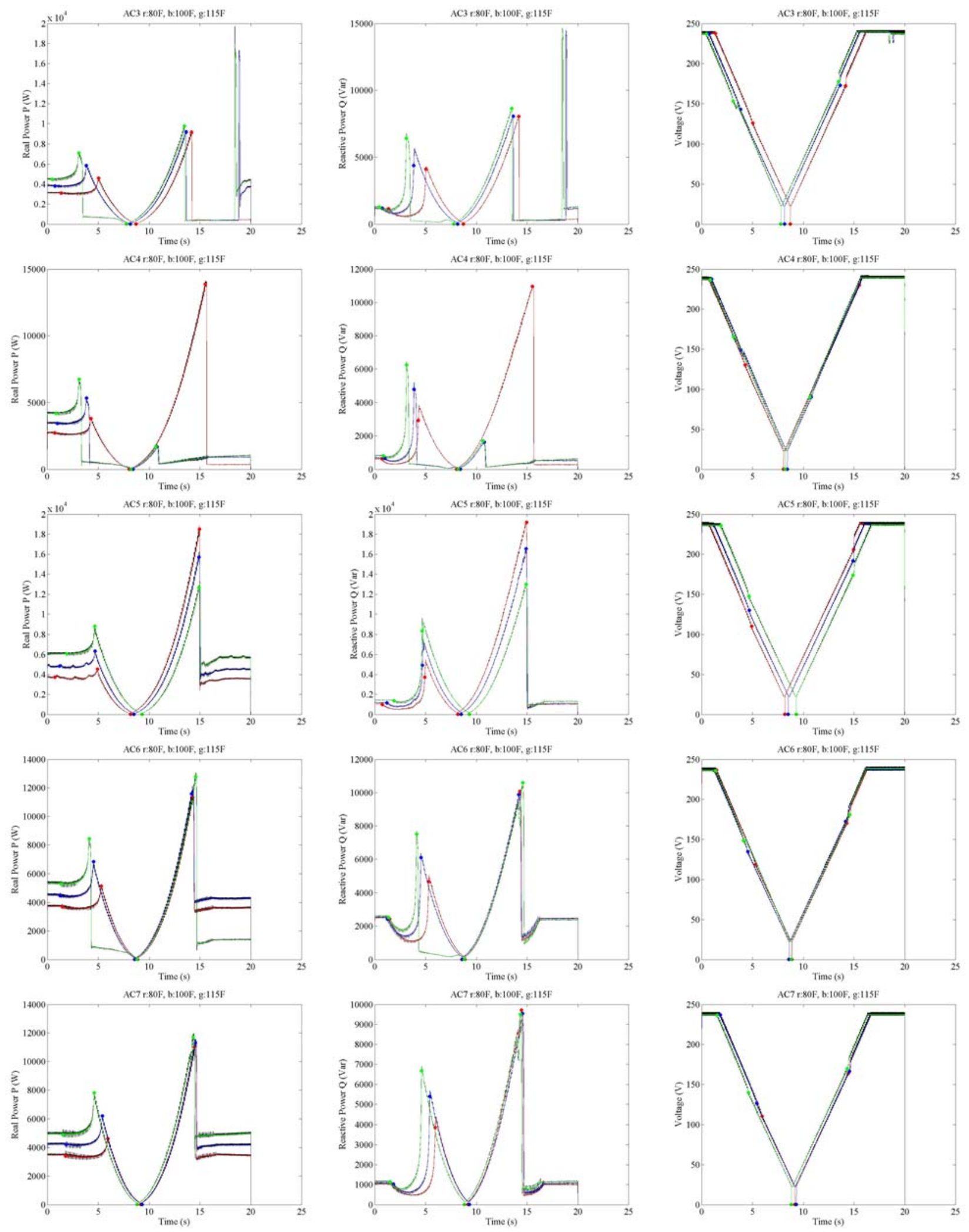

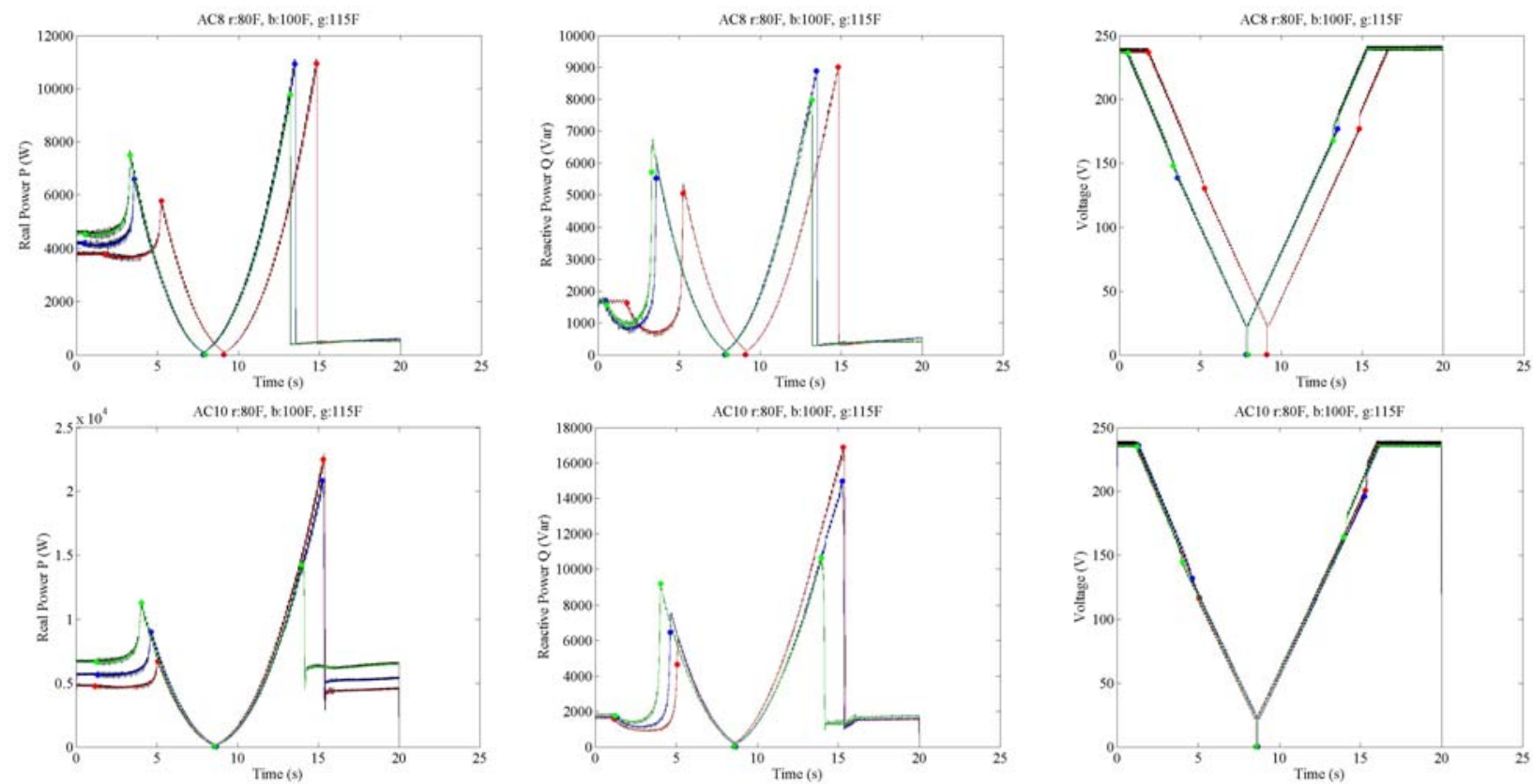

Figure B.1. Original Test Results (black) and Filtered P (left), Q (middle) and V (right) Time Series at Temperatures of $80^{\circ} \mathrm{F}$ (red), $100^{\circ} \mathrm{F}$ (blue) and $115^{\circ} \mathrm{F}$ (green) for the $7 \mathrm{Air}$ Conditioners (ACs) Used (from top to bottom, AC name is displayed in the plot title) 

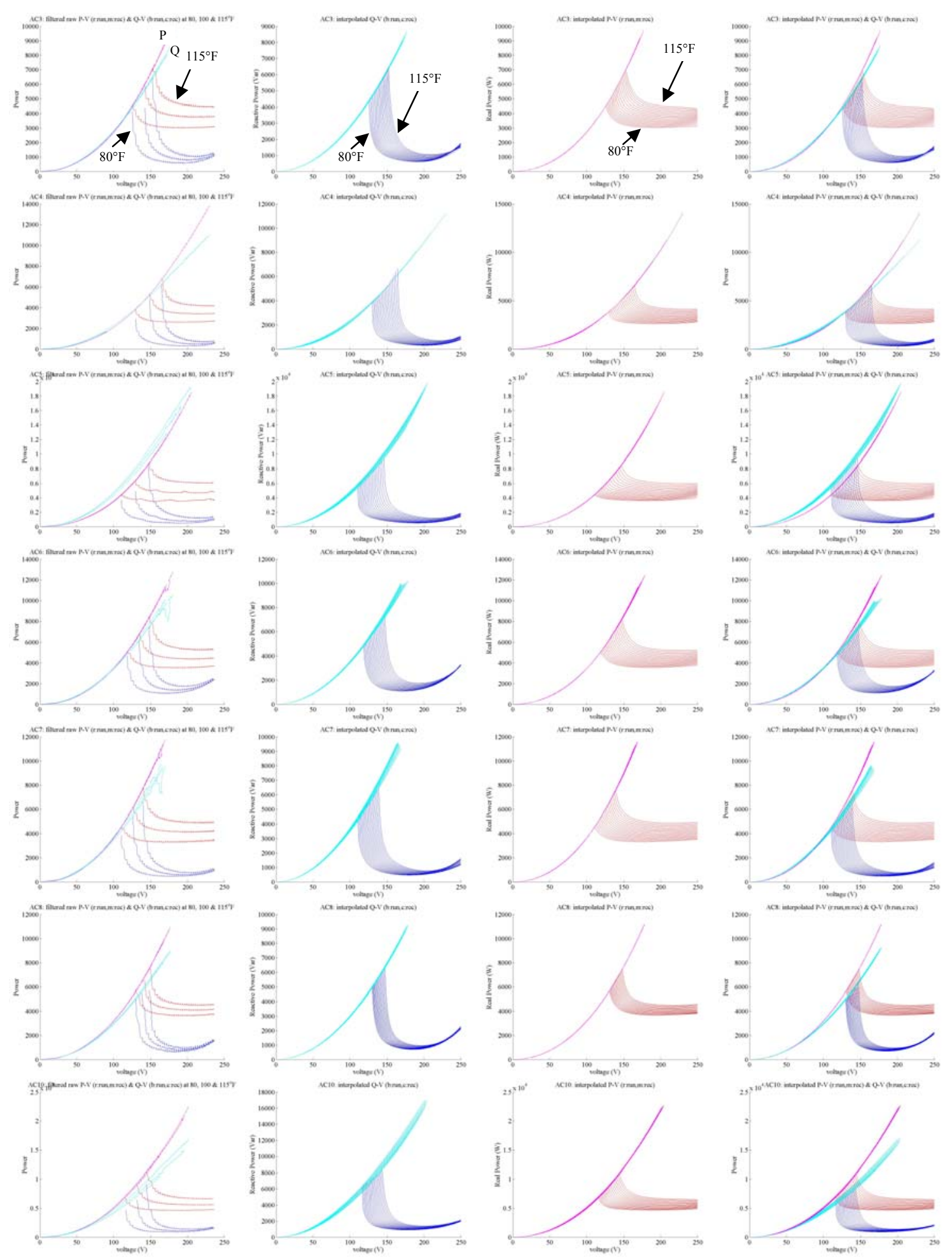

Figure B.2. Raw Filtered P-V and Q-V at Three Temperatures (panel 1) and Interpolated P-V (panel 2), $\mathrm{Q}-\mathrm{V}$ (panel 3), and $\mathrm{P}-\mathrm{V} / \mathrm{Q}-\mathrm{V}$ together (panel 4) at Several Temperatures Between $80^{\circ} \mathrm{F}$ and $115^{\circ} \mathrm{F}$ for the 7 ACs Used (from top to bottom) (red: ramp-down P-V; magenta: ramp-up P-V; blue: ramp-down Q-V; cyan: ramp-up Q-V) 

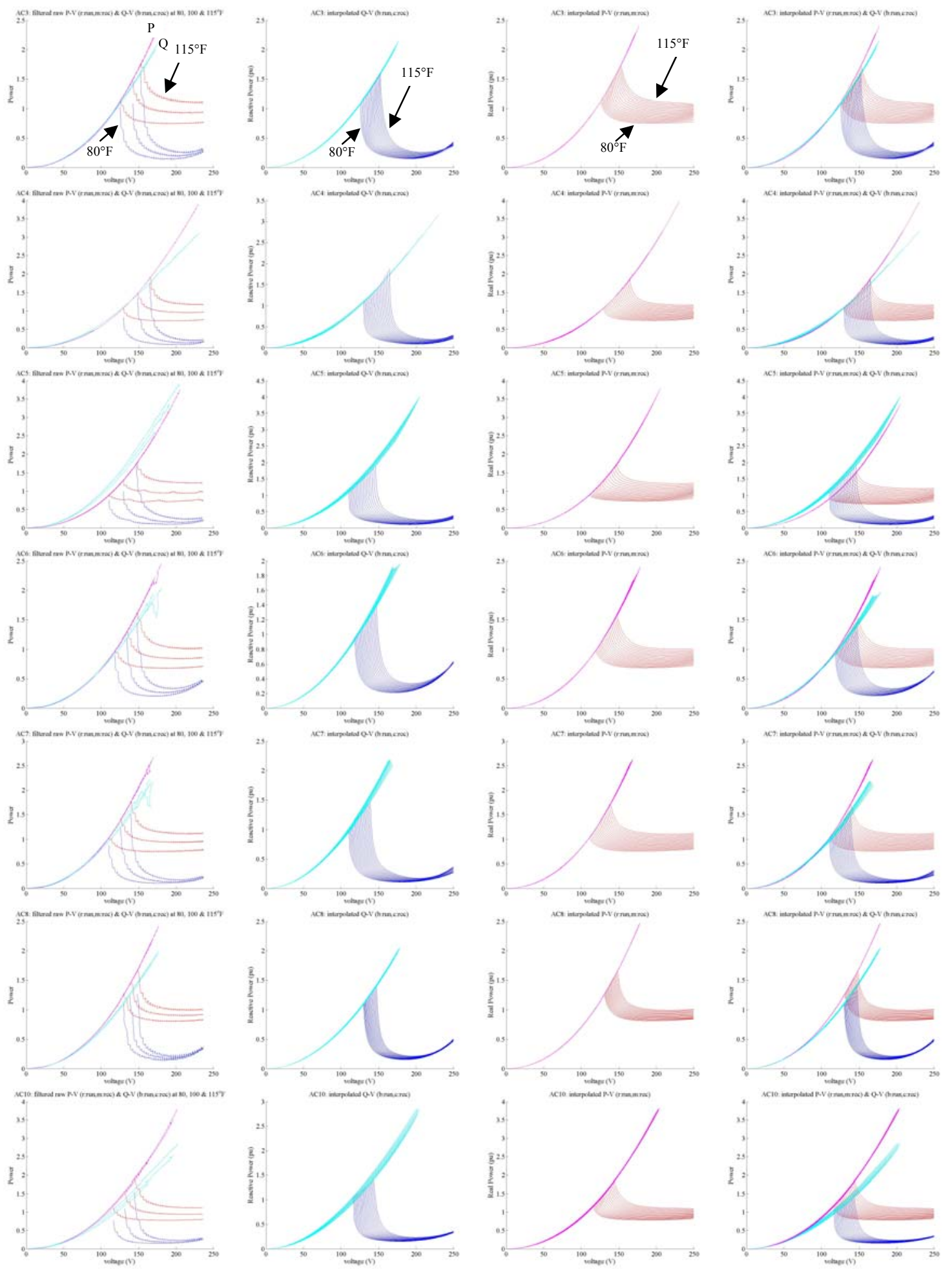

Figure B.3. Normalized Filtered P-V and Q-V at Three Temperatures (panel 1) and Interpolated Normalized P-V (panel 2), Q-V (panel 3), and P-V/Q-V Together (panel 4) at Several Temperatures Between $80^{\circ} \mathrm{F}$ and $115^{\circ} \mathrm{F}$ for the $7 \mathrm{ACs}$ Used (from top to bottom) (red: ramp-down P-V; magenta: ramp-up P-V; blue: ramp-down Q-V; cyan: ramp-up Q-V) 


\section{$\underline{80}^{\circ} \mathbf{F}$}
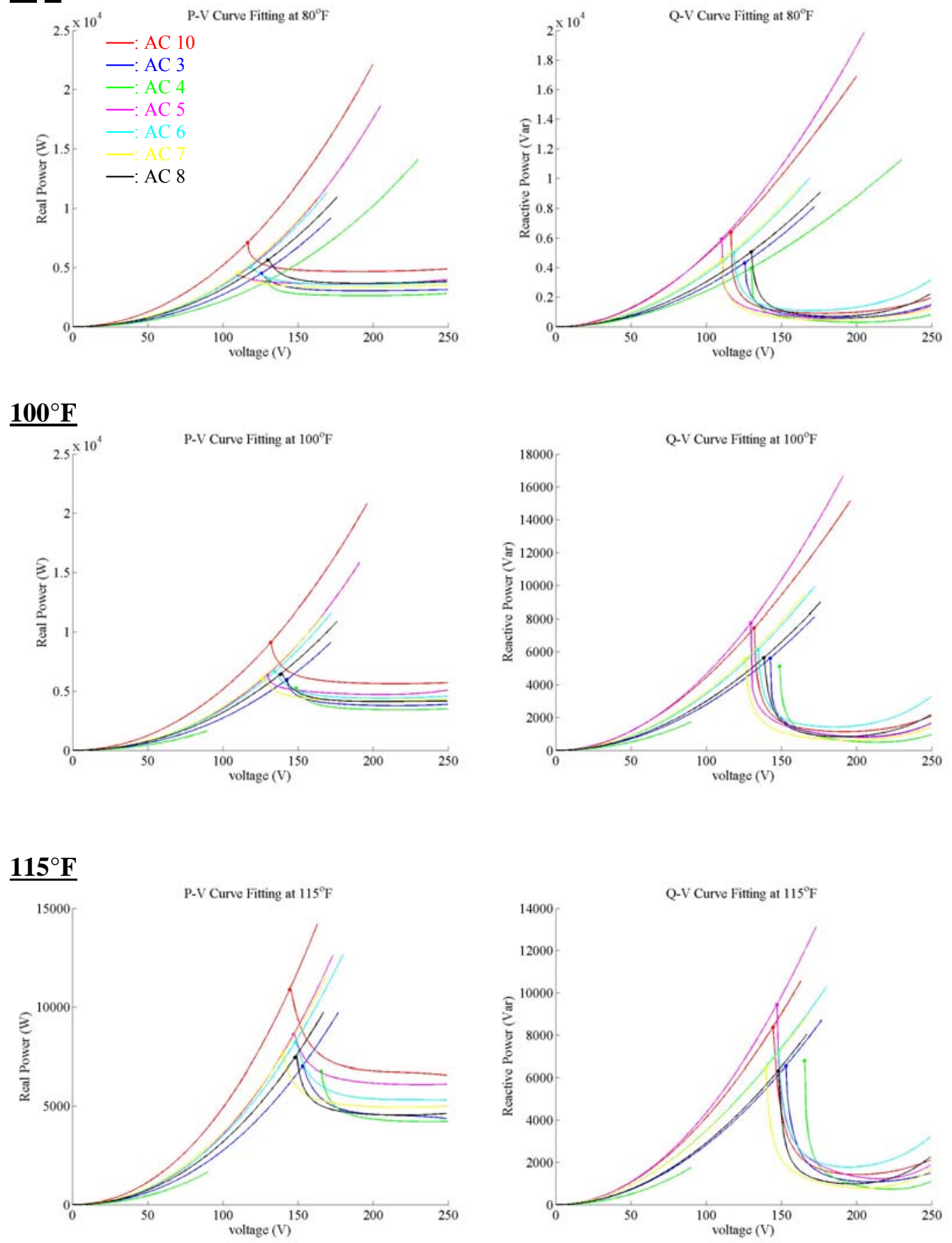

Figure B.4. Fitted P-V/Q-V Curves of All 7 AC Motors at Three Temperatures Based on Raw Filtered Data 

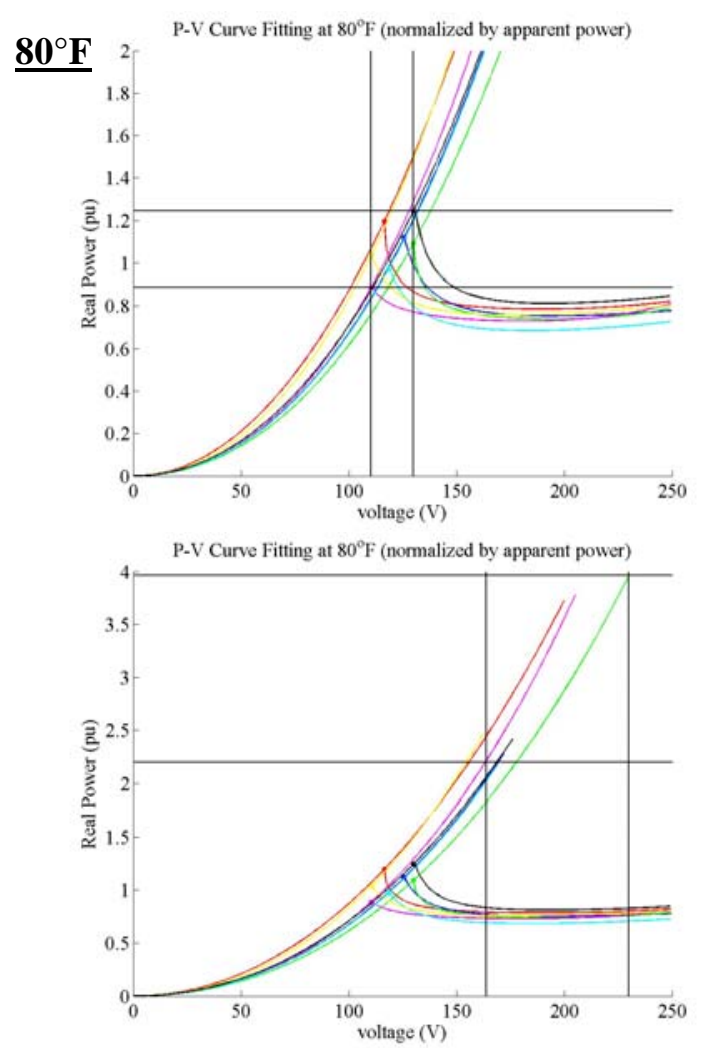

$\underline{100^{\circ} \mathrm{F}}$
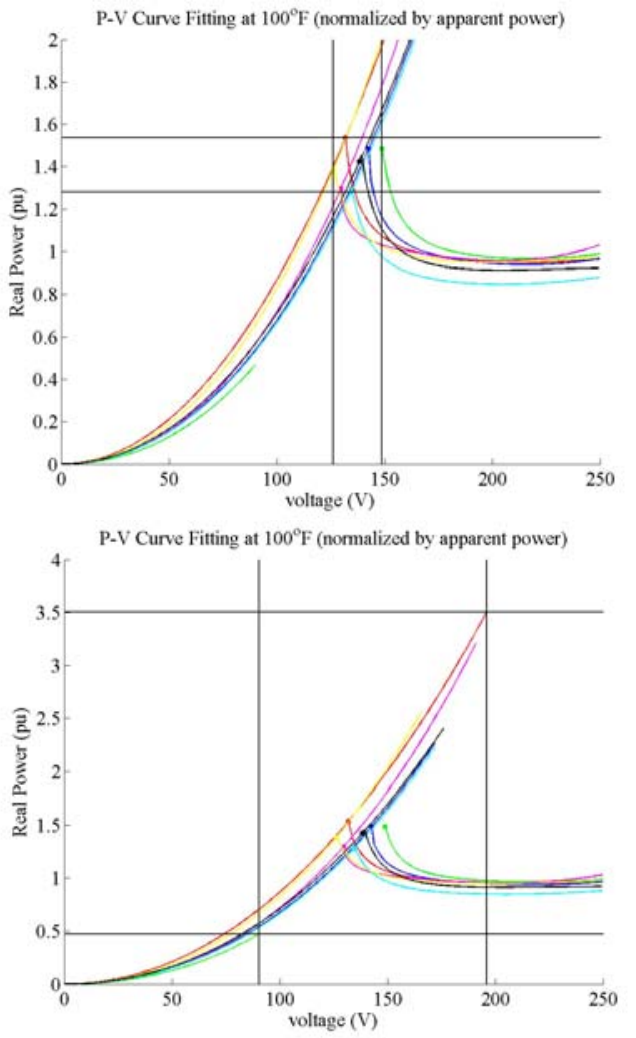
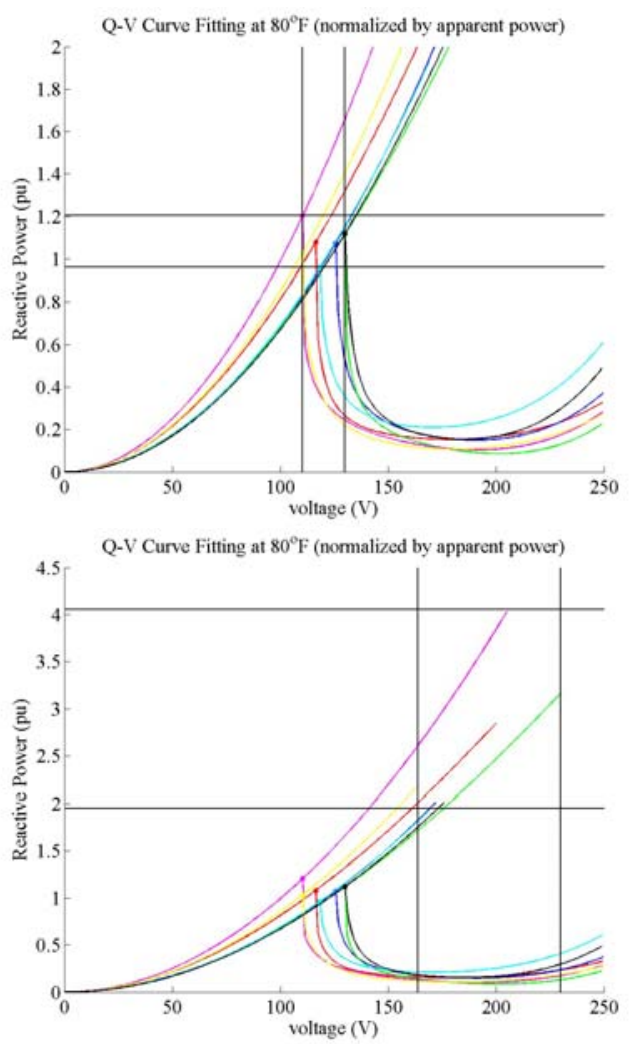

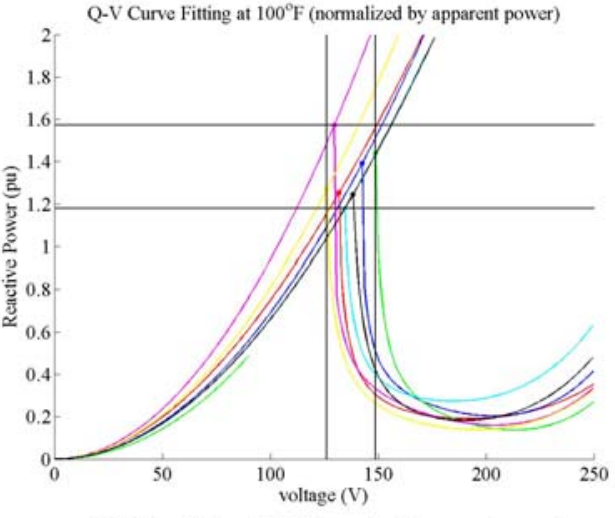

Q-V Curve Fitting at $100^{\circ} \mathrm{F}$ (normalized by apparent power)

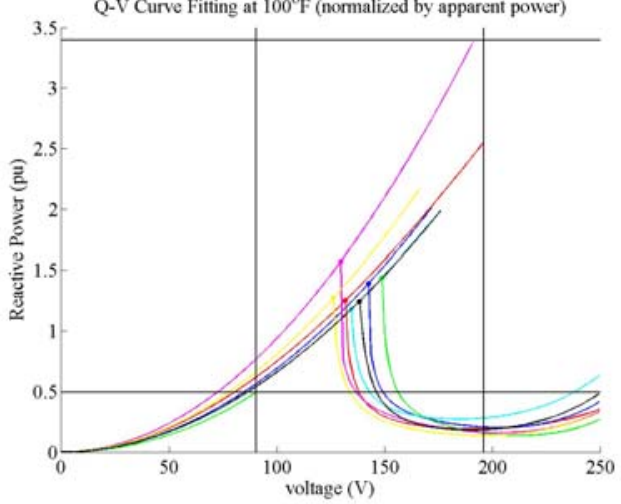




\section{$\underline{115^{\circ} \mathrm{F}}$}
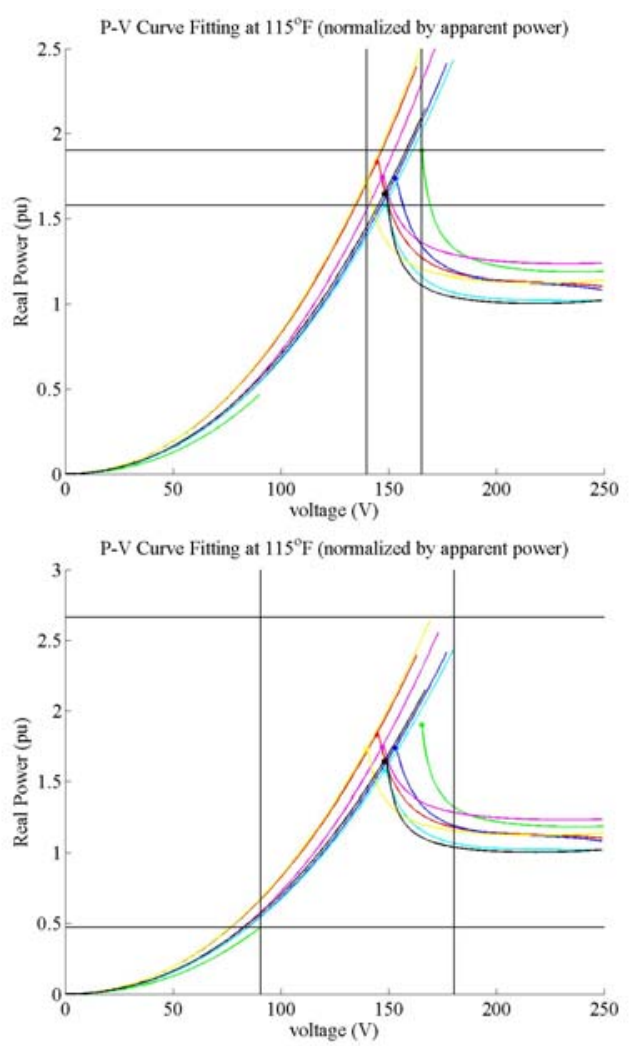

Q-V Curve Fitting at $115^{\circ} \mathrm{F}$ (normalized by apparent power)

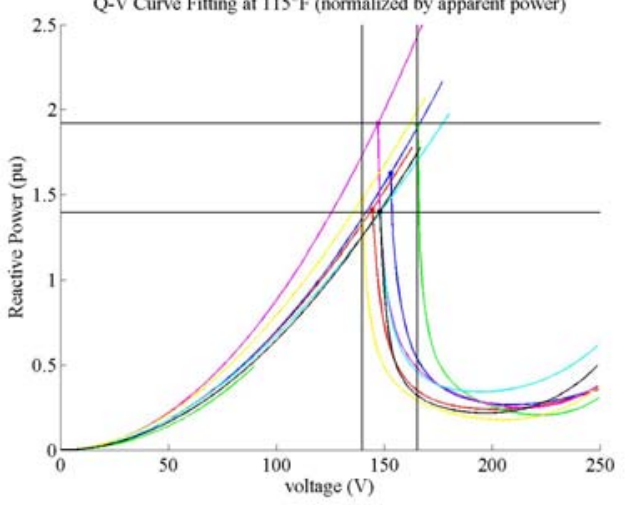

Q-V Curve Fitting at $115^{\circ} \mathrm{F}$ (normalized by apparent power)

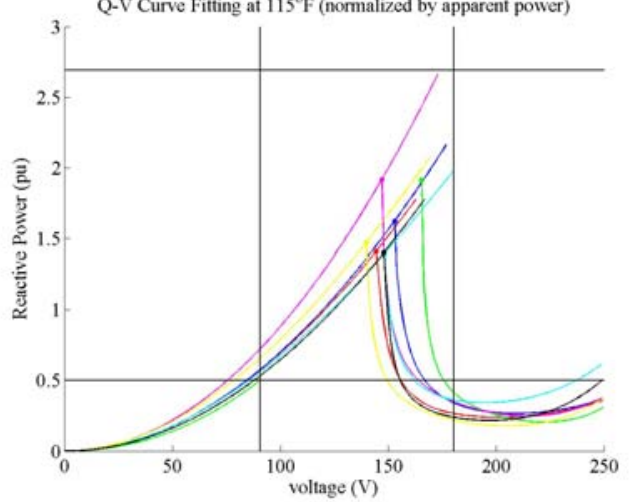

Figure B.5. Fitted P-V/Q-V Curves of All AC Motors at Three Temperatures Based on Normalized Filtered Data

Table B.2. Optimal Parameters for Curve-Fitting P-V and Q-V Curves on Raw Filtered Data at $80^{\circ} \mathrm{F}$

\begin{tabular}{|c|c|c|c|c|c|c|c|}
\hline \multirow{2}{*}{$\frac{\mathbf{P}-\mathbf{V}}{\mathrm{AC}}$} & \multicolumn{5}{|c|}{ Rampdown } & \multicolumn{2}{|c|}{ Rampup } \\
\hline & $\mathrm{b}(0) \_\mathrm{P}($ run $)$ & $\mathrm{b}(1) \_\mathrm{P}($ run $)$ & $\mathrm{b}(2) \_\mathrm{P}($ run $)$ & $\mathrm{b}(3) \_\mathrm{P}($ run $)$ & $\mathrm{b}(4) \_\mathrm{P}(\mathrm{run})$ & $\mathrm{k}(1) \_\mathrm{P}(\mathrm{rec})$ & $\mathrm{k}(2) \_\mathrm{P}(\mathrm{rec})$ \\
\hline $\mathrm{AC} 10$ & $1.095 \mathrm{E}+02$ & $4.367 \mathrm{E}+03$ & $1.567 \mathrm{E}+04$ & $9.737 \mathrm{E}-01$ & $7.095 \mathrm{E}-07$ & $3.560 \mathrm{E}-04$ & $4.825 \mathrm{E}-01$ \\
\hline AC3 & $1.144 \mathrm{E}+02$ & $2.471 \mathrm{E}+03$ & $2.278 \mathrm{E}+04$ & $3.527 \mathrm{E}+00$ & $6.601 \mathrm{E}-08$ & $5.426 \mathrm{E}-04$ & $2.175 \mathrm{E}-01$ \\
\hline $\mathrm{AC} 4$ & $1.233 \mathrm{E}+02$ & $2.484 \mathrm{E}+03$ & $7.972 \mathrm{E}+03$ & $6.191 \mathrm{E}-02$ & $1.012 \mathrm{E}-06$ & $3.636 \mathrm{E}-04$ & $1.826 \mathrm{E}-01$ \\
\hline AC5 & $9.847 \mathrm{E}+01$ & $3.486 \mathrm{E}+03$ & $1.101 \mathrm{E}+04$ & $-8.683 \mathrm{E}-01$ & $1.097 \mathrm{E}-06$ & $8.899 \mathrm{E}-04$ & $2.608 \mathrm{E}-01$ \\
\hline AC6 & $1.052 \mathrm{E}+02$ & $2.843 \mathrm{E}+03$ & $3.011 \mathrm{E}+04$ & $4.157 \mathrm{E}+00$ & $3.118 \mathrm{E}-07$ & $6.911 \mathrm{E}-04$ & $2.785 \mathrm{E}-01$ \\
\hline AC7 & $9.634 \mathrm{E}+01$ & $2.674 \mathrm{E}+03$ & $2.603 \mathrm{E}+04$ & $4.117 \mathrm{E}+00$ & $9.714 \mathrm{E}-08$ & $7.178 \mathrm{E}-04$ & $2.938 \mathrm{E}-01$ \\
\hline $\mathrm{AC} 8$ & $1.216 \mathrm{E}+02$ & $3.044 \mathrm{E}+03$ & $2.339 \mathrm{E}+04$ & $4.199 \mathrm{E}+00$ & $2.665 \mathrm{E}-07$ & $4.291 \mathrm{E}-04$ & $2.775 \mathrm{E}-01$ \\
\hline Q-V & \multicolumn{5}{|c|}{ Rampdown } & \multicolumn{2}{|c|}{ Rampup } \\
\hline $\mathrm{AC}$ & $\mathrm{b}(0) \_\mathrm{Q}$ (run) & $\mathrm{b}(1) \_\mathrm{Q}$ (run) & $\mathrm{b}(2) \_\mathrm{Q}$ (run) & $\mathrm{b}(3) \_\mathrm{Q}$ (run) & $\mathrm{b}(4) \_\mathrm{Q}$ (run) & $\mathrm{k}(1) \_\mathrm{Q}(\mathrm{rec})$ & $\mathrm{k}(2) \_\mathrm{Q}(\mathrm{rec})$ \\
\hline $\mathrm{AC} 10$ & $1.117 \mathrm{E}+02$ & $5.816 \mathrm{E}+02$ & $1.805 \mathrm{E}+04$ & $-1.061 \mathrm{E}-01$ & $3.457 \mathrm{E}-06$ & $-5.978 \mathrm{E}-04$ & $5.419 \mathrm{E}-01$ \\
\hline $\mathrm{AC} 3$ & $1.211 \mathrm{E}+02$ & $5.291 \mathrm{E}+02$ & $1.442 \mathrm{E}+04$ & $-3.493 \mathrm{E}+00$ & $4.791 \mathrm{E}-06$ & $1.125 \mathrm{E}-05$ & $2.723 \mathrm{E}-01$ \\
\hline AC4 & $1.258 \mathrm{E}+02$ & $4.631 \mathrm{E}+02$ & $8.911 \mathrm{E}+03$ & $-5.360 \mathrm{E}+00$ & $4.002 \mathrm{E}-06$ & $-2.168 \mathrm{E}-04$ & $2.625 \mathrm{E}-01$ \\
\hline AC5 & $1.039 \mathrm{E}+02$ & $7.395 \mathrm{E}+02$ & $1.694 \mathrm{E}+04$ & $-7.135 \mathrm{E}+00$ & 3.501E-06 & $-1.484 \mathrm{E}-04$ & $5.031 \mathrm{E}-01$ \\
\hline AC6 & $1.126 \mathrm{E}+02$ & $5.558 \mathrm{E}+02$ & $2.185 \mathrm{E}+04$ & $1.568 \mathrm{E}+00$ & $6.354 \mathrm{E}-06$ & $-1.156 \mathrm{E}-04$ & $3.705 \mathrm{E}-01$ \\
\hline AC7 & $1.033 \mathrm{E}+02$ & $5.700 \mathrm{E}+01$ & $2.420 \mathrm{E}+04$ & $4.359 \mathrm{E}-01$ & $1.988 \mathrm{E}-06$ & $-2.503 \mathrm{E}-04$ & $3.985 \mathrm{E}-01$ \\
\hline AC8 & $1.261 \mathrm{E}+02$ & $4.209 \mathrm{E}+02$ & $1.737 \mathrm{E}+04$ & $-1.980 \mathrm{E}+00$ & $8.232 \mathrm{E}-06$ & $-1.224 \mathrm{E}-04$ & $3.153 \mathrm{E}-01$ \\
\hline
\end{tabular}

\begin{tabular}{|c|c|l|}
\hline V critical & Rampdown & Rampup \\
\hline AC & peak V(run) & peak V(rec) \\
\hline AC10 & $1.164 \mathrm{E}+02$ & $2.009 \mathrm{E}+02$ \\
AC3 & $1.257 \mathrm{E}+02$ & $1.721 \mathrm{E}+02$ \\
AC4 & $1.300 \mathrm{E}+02$ & $2.300 \mathrm{E}+02$ \\
AC5 & $1.104 \mathrm{E}+02$ & $2.057 \mathrm{E}+02$ \\
AC6 & $1.185 \mathrm{E}+02$ & $1.700 \mathrm{E}+02$ \\
AC7 & $1.105 \mathrm{E}+02$ & $1.638 \mathrm{E}+02$ \\
AC8 & $1.301 \mathrm{E}+02$ & $1.769 \mathrm{E}+02$ \\
\hline
\end{tabular}


Tab;le B.2. Continued

\section{At $100^{\circ} \mathrm{F}$}

\begin{tabular}{|c|c|c|c|c|c|c|c|}
\hline \multirow{2}{*}{$\frac{\mathbf{P}-\mathbf{V}}{\mathrm{AC}}$} & \multicolumn{5}{|c|}{ Rampdown } & \multicolumn{2}{|c|}{ Rampup } \\
\hline & $\mathrm{b}(0) \_\mathrm{P}(\mathrm{run})$ & $\mathrm{b}(1) \_\mathrm{P}($ run $)$ & $\mathrm{b}(2) \_\mathrm{P}($ run $)$ & $\mathrm{b}(3) \_\mathrm{P}($ run $)$ & $\mathrm{b}(4) \_\mathrm{P}($ run $)$ & $\mathrm{k}(1) \_\mathrm{P}(\mathrm{rec})$ & $\mathrm{k}(2) \_\mathrm{P}(\mathrm{rec})$ \\
\hline $\mathrm{AC} 10$ & $1.242 \mathrm{E}+02$ & $5.138 \mathrm{E}+03$ & $2.944 \mathrm{E}+04$ & $1.394 \mathrm{E}+00$ & $7.169 \mathrm{E}-07$ & $2.724 \mathrm{E}-04$ & $4.882 \mathrm{E}-01$ \\
\hline $\mathrm{AC} 3$ & $1.356 \mathrm{E}+02$ & $3.629 \mathrm{E}+03$ & $1.414 \mathrm{E}+04$ & $-1.079 \mathrm{E}+00$ & $1.563 \mathrm{E}-06$ & $4.918 \mathrm{E}-04$ & $2.241 \mathrm{E}-01$ \\
\hline $\mathrm{AC} 4$ & $1.416 \mathrm{E}+02$ & $3.111 \mathrm{E}+03$ & $1.604 \mathrm{E}+04$ & $9.956 \mathrm{E}-01$ & $1.061 \mathrm{E}-06$ & $5.621 \mathrm{E}-04$ & $1.546 \mathrm{E}-01$ \\
\hline AC5 & $1.248 \mathrm{E}+02$ & $4.971 \mathrm{E}+03$ & $5.982 \mathrm{E}+03$ & $-5.754 \mathrm{E}+00$ & $3.232 \mathrm{E}-06$ & $8.764 \mathrm{E}-04$ & $2.662 \mathrm{E}-01$ \\
\hline AC6 & $1.250 \mathrm{E}+02$ & $3.803 \mathrm{E}+03$ & $2.871 \mathrm{E}+04$ & $2.683 \mathrm{E}+00$ & $8.942 \mathrm{E}-07$ & $6.285 \mathrm{E}-04$ & $2.832 \mathrm{E}-01$ \\
\hline AC7 & $1.162 \mathrm{E}+02$ & $3.612 \mathrm{E}+03$ & $2.575 \mathrm{E}+04$ & $2.853 \mathrm{E}+00$ & $3.331 \mathrm{E}-07$ & $6.998 \mathrm{E}-04$ & $2.936 \mathrm{E}-01$ \\
\hline $\mathrm{AC} 8$ & $1.303 \mathrm{E}+02$ & $3.295 \mathrm{E}+03$ & $2.929 \mathrm{E}+04$ & $6.187 \mathrm{E}+00$ & $-5.167 \mathrm{E}-07$ & $3.986 \mathrm{E}-04$ & $2.812 \mathrm{E}-01$ \\
\hline
\end{tabular}

\begin{tabular}{|c|ccccc|cc|}
\hline Q-V & \multicolumn{3}{|c|}{ Rampdown } & \multicolumn{2}{c|}{ Rampup } \\
\hline AC & $\mathrm{b}(0) \_\mathrm{Q}($ run $)$ & $\mathrm{b}(1) \_\mathrm{Q}($ run $)$ & $\mathrm{b}(2) \_\mathrm{Q}($ run $)$ & $\mathrm{b}(3) \_\mathrm{Q}($ run $)$ & $\mathrm{b}(4) \_\mathrm{Q}($ run $)$ & $\mathrm{k}(1) \_\mathrm{Q}($ rec $)$ & $\mathrm{k}(2) \_\mathrm{Q}(\mathrm{rec})$ \\
\hline $\mathrm{AC} 10$ & $1.275 \mathrm{E}+02$ & $6.632 \mathrm{E}+02$ & $2.427 \mathrm{E}+04$ & $3.750 \mathrm{E}-02$ & $5.481 \mathrm{E}-06$ & $-5.162 \mathrm{E}-04$ & $4.956 \mathrm{E}-01$ \\
$\mathrm{AC} 3$ & $1.386 \mathrm{E}+02$ & $9.528 \mathrm{E}+02$ & $1.197 \mathrm{E}+04$ & $-7.447 \mathrm{E}+00$ & $9.430 \mathrm{E}-06$ & $-4.287 \mathrm{E}-05$ & $2.819 \mathrm{E}-01$ \\
AC4 & $1.454 \mathrm{E}+02$ & $6.018 \mathrm{E}+02$ & $1.350 \mathrm{E}+04$ & $-7.112 \mathrm{E}+00$ & $8.097 \mathrm{E}-06$ & $2.889 \mathrm{E}-04$ & $1.875 \mathrm{E}-01$ \\
AC5 & $1.243 \mathrm{E}+02$ & $1.218 \mathrm{E}+03$ & $1.722 \mathrm{E}+04$ & $-1.164 \mathrm{E}+01$ & $7.084 \mathrm{E}-06$ & $-6.569 \mathrm{E}-05$ & $4.691 \mathrm{E}-01$ \\
AC6 & $1.302 \mathrm{E}+02$ & $9.307 \mathrm{E}+02$ & $2.110 \mathrm{E}+04$ & $2.054 \mathrm{E}-01$ & $1.058 \mathrm{E}-05$ & $-1.045 \mathrm{E}-04$ & $3.531 \mathrm{E}-01$ \\
AC7 & $1.213 \mathrm{E}+02$ & $4.373 \mathrm{E}+02$ & $2.237 \mathrm{E}+04$ & $-3.631 \mathrm{E}+00$ & $4.711 \mathrm{E}-06$ & $-1.554 \mathrm{E}-04$ & $3.700 \mathrm{E}-01$ \\
AC8 & $1.339 \mathrm{E}+02$ & $1.889 \mathrm{E}+02$ & $2.517 \mathrm{E}+04$ & $1.836 \mathrm{E}+00$ & $8.670 \mathrm{E}-06$ & $-1.147 \mathrm{E}-04$ & $3.100 \mathrm{E}-01$ \\
\hline
\end{tabular}

\begin{tabular}{|c|c|c|}
\hline V critical & Rampdown & Rampup \\
\hline AC & peak_V(run) & peak_V(rec) \\
\hline AC10 & $1.320 \mathrm{E}+02$ & $1.960 \mathrm{E}+02$ \\
AC3 & $1.426 \mathrm{E}+02$ & $1.728 \mathrm{E}+02$ \\
AC4 & $1.489 \mathrm{E}+02$ & $9.049 \mathrm{E}+01$ \\
AC5 & $1.297 \mathrm{E}+02$ & $1.915 \mathrm{E}+02$ \\
AC6 & $1.345 \mathrm{E}+02$ & $1.723 \mathrm{E}+02$ \\
AC7 & $1.262 \mathrm{E}+02$ & $1.664 \mathrm{E}+02$ \\
AC8 & $1.384 \mathrm{E}+02$ & $1.769 \mathrm{E}+02$ \\
\hline
\end{tabular}

\section{At $115^{\circ} \mathrm{F}$}

\begin{tabular}{|c|c|c|c|c|c|c|c|}
\hline \multirow{2}{*}{$\begin{array}{l}\mathbf{P}-\mathbf{V} \\
\mathrm{AC}\end{array}$} & \multicolumn{5}{|c|}{ Rampdown } & \multicolumn{2}{|c|}{ Rampup } \\
\hline & $\mathrm{b}(0) \_\mathrm{P}($ run $)$ & $\mathrm{b}(1) \_\mathrm{P}($ run $)$ & $\mathrm{b}(2) \_\mathrm{P}($ run $)$ & $\mathrm{b}(3) \_\mathrm{P}($ run $)$ & $\mathrm{b}(4) \_\mathrm{P}($ run $)$ & $\mathrm{k}(1) \_\mathrm{P}(\mathrm{rec})$ & $\mathrm{k}(2) \_\mathrm{P}(\mathrm{rec})$ \\
\hline $\mathrm{AC} 10$ & $1.324 \mathrm{E}+02$ & $4.696 \mathrm{E}+03$ & $7.797 \mathrm{E}+04$ & $1.463 \mathrm{E}+01$ & $-2.745 \mathrm{E}-06$ & $7.063 \mathrm{E}-04$ & $4.199 \mathrm{E}-01$ \\
\hline $\mathrm{AC} 3$ & $1.398 \mathrm{E}+02$ & $3.013 \mathrm{E}+03$ & $5.306 \mathrm{E}+04$ & $1.218 \mathrm{E}+01$ & $-3.227 \mathrm{E}-06$ & $4.741 \mathrm{E}-04$ & $2.265 \mathrm{E}-01$ \\
\hline $\mathrm{AC} 4$ & $1.595 \mathrm{E}+02$ & $3.881 \mathrm{E}+03$ & $1.679 \mathrm{E}+04$ & $1.065 \mathrm{E}+00$ & $8.984 \mathrm{E}-07$ & $5.642 \mathrm{E}-04$ & $1.533 \mathrm{E}-01$ \\
\hline $\mathrm{AC} 5$ & $1.383 \mathrm{E}+02$ & $5.588 \mathrm{E}+03$ & $2.892 \mathrm{E}+04$ & $1.559 \mathrm{E}+00$ & $5.239 \mathrm{E}-07$ & $8.834 \mathrm{E}-04$ & $2.678 \mathrm{E}-01$ \\
\hline AC6 & $1.360 \mathrm{E}+02$ & $3.893 \mathrm{E}+03$ & $5.376 \mathrm{E}+04$ & $1.025 \mathrm{E}+01$ & $-1.361 \mathrm{E}-06$ & $5.128 \mathrm{E}-04$ & $2.981 \mathrm{E}-01$ \\
\hline AC7 & $1.323 \mathrm{E}+02$ & $4.503 E+03$ & $2.445 \mathrm{E}+04$ & $1.356 \mathrm{E}+00$ & $7.301 \mathrm{E}-07$ & $5.578 \mathrm{E}-04$ & $3.110 \mathrm{E}-01$ \\
\hline $\mathrm{AC} 8$ & $1.438 \mathrm{E}+02$ & $4.183 \mathrm{E}+03$ & $1.740 \mathrm{E}+04$ & $1.209 \mathrm{E}+00$ & $1.215 \mathrm{E}-06$ & $4.525 \mathrm{E}-04$ & $2.727 \mathrm{E}-01$ \\
\hline Q-V & \multicolumn{5}{|c|}{ Rampdown } & \multicolumn{2}{|c|}{ Rampup } \\
\hline $\mathrm{AC}$ & $\mathrm{b}(0) \_\mathrm{Q}$ (run) & $\mathrm{b}(1) \_\mathrm{Q}$ (run) & $\mathrm{b}(2) \_\mathrm{Q}$ (run) & $\mathrm{b}(3) \_\mathrm{Q}$ (run) & $\mathrm{b}(4) \mathrm{Q}$ (run) & $\mathrm{k}(1) \mathrm{Q}(\mathrm{rec})$ & $\mathrm{k}(2) \mathrm{Q}(\mathrm{rec})$ \\
\hline $\mathrm{AC} 10$ & $1.394 \mathrm{E}+02$ & $2.358 \mathrm{E}+02$ & $4.312 \mathrm{E}+04$ & $6.743 \mathrm{E}+00$ & $5.137 \mathrm{E}-06$ & $-2.339 \mathrm{E}-04$ & $4.354 \mathrm{E}-01$ \\
\hline $\mathrm{AC} 3$ & $1.468 \mathrm{E}+02$ & $1.684 \mathrm{E}+02$ & $3.564 \mathrm{E}+04$ & $4.190 \mathrm{E}+00$ & 4.957E-06 & $-4.772 \mathrm{E}-05$ & $2.868 \mathrm{E}-01$ \\
\hline $\mathrm{AC} 4$ & $1.625 \mathrm{E}+02$ & $8.868 \mathrm{E}+02$ & $1.367 \mathrm{E}+04$ & $-9.776 \mathrm{E}+00$ & $1.554 \mathrm{E}-05$ & $4.158 \mathrm{E}-04$ & $1.793 \mathrm{E}-01$ \\
\hline AC5 & $1.432 \mathrm{E}+02$ & $1.481 \mathrm{E}+03$ & $2.636 \mathrm{E}+04$ & $-1.313 \mathrm{E}+01$ & $1.212 \mathrm{E}-05$ & $6.504 \mathrm{E}-05$ & 4.273E-01 \\
\hline AC6 & $1.424 \mathrm{E}+02$ & $6.413 \mathrm{E}+02$ & $3.641 \mathrm{E}+04$ & $6.822 \mathrm{E}+00$ & $1.151 \mathrm{E}-05$ & $-4.148 \mathrm{E}-04$ & $3.914 \mathrm{E}-01$ \\
\hline AC7 & $1.363 \mathrm{E}+02$ & $8.539 \mathrm{E}+02$ & $1.938 \mathrm{E}+04$ & $-8.176 \mathrm{E}+00$ & $9.311 \mathrm{E}-06$ & $-4.298 \mathrm{E}-04$ & $3.905 \mathrm{E}-01$ \\
\hline $\mathrm{AC} 8$ & $1.453 \mathrm{E}+02$ & $6.292 \mathrm{E}+02$ & $1.697 \mathrm{E}+04$ & $-1.412 \mathrm{E}+00$ & $1.389 \mathrm{E}-05$ & $-5.481 \mathrm{E}-05$ & $2.975 \mathrm{E}-01$ \\
\hline
\end{tabular}

\begin{tabular}{|c|c|l|}
\hline V critical & Rampdown & Rampup \\
\hline AC & peak_V(run) & peak_V(rec) \\
\hline AC10 & $1.444 \mathrm{E}+02$ & $1.639 \mathrm{E}+02$ \\
AC3 & $1.530 \mathrm{E}+02$ & $1.776 \mathrm{E}+02$ \\
AC4 & $1.655 \mathrm{E}+02$ & $9.065 \mathrm{E}+01$ \\
AC5 & $1.471 \mathrm{E}+02$ & $1.739 \mathrm{E}+02$ \\
AC6 & $1.481 \mathrm{E}+02$ & $1.805 \mathrm{E}+02$ \\
AC7 & $1.398 \mathrm{E}+02$ & $1.698 \mathrm{E}+02$ \\
AC8 & $1.480 \mathrm{E}+02$ & $1.678 \mathrm{E}+02$ \\
\hline
\end{tabular}


Tab;le B.2. Continued

\begin{tabular}{|c|c|c|c|c|c|c|c|}
\hline \multirow{2}{*}{$\frac{\mathbf{P}-\mathbf{V}}{\mathrm{AC}}$} & \multicolumn{5}{|c|}{ Rampdown } & \multicolumn{2}{|c|}{ Rampup } \\
\hline & $\mathrm{b}(0) \_\mathrm{P}($ run $)$ & $\mathrm{b}(1) \mathrm{P}$ (run) & $\mathrm{b}(2) \_\mathrm{P}($ run $)$ & $\mathrm{b}(3) \mathrm{P}$ (run) & $\mathrm{b}(4) \mathrm{P}$ (run) & $\mathrm{k}(1) \_\mathrm{P}(\mathrm{rec})$ & $\mathrm{k}(2) \_\mathrm{P}(\mathrm{rec})$ \\
\hline $\mathrm{AC} 10$ & $1.095 \mathrm{E}+02$ & $7.353 \mathrm{E}-01$ & $2.639 \mathrm{E}+00$ & $1.640 \mathrm{E}-04$ & $1.195 \mathrm{E}-10$ & $5.994 \mathrm{E}-08$ & $8.125 \mathrm{E}-05$ \\
\hline $\mathrm{AC} 3$ & $1.144 \mathrm{E}+02$ & $6.130 \mathrm{E}-01$ & $5.651 \mathrm{E}+00$ & $8.749 \mathrm{E}-04$ & $1.637 \mathrm{E}-11$ & $1.346 \mathrm{E}-07$ & $5.396 \mathrm{E}-05$ \\
\hline $\mathrm{AC} 4$ & $1.233 \mathrm{E}+02$ & $6.990 \mathrm{E}-01$ & $2.243 \mathrm{E}+00$ & $1.741 \mathrm{E}-05$ & $2.847 \mathrm{E}-10$ & $1.023 \mathrm{E}-07$ & $5.137 \mathrm{E}-05$ \\
\hline AC5 & $9.847 \mathrm{E}+01$ & $7.071 \mathrm{E}-01$ & $2.233 \mathrm{E}+00$ & $-1.762 \mathrm{E}-04$ & $2.225 \mathrm{E}-10$ & $1.805 \mathrm{E}-07$ & $5.291 \mathrm{E}-05$ \\
\hline AC6 & $1.052 \mathrm{E}+02$ & $5.466 \mathrm{E}-01$ & $5.788 \mathrm{E}+00$ & $7.992 \mathrm{E}-04$ & $5.994 \mathrm{E}-11$ & $1.329 \mathrm{E}-07$ & $5.355 \mathrm{E}-05$ \\
\hline $\mathrm{AC} 7$ & $9.634 \mathrm{E}+01$ & $6.088 \mathrm{E}-01$ & $5.925 \mathrm{E}+00$ & $9.371 \mathrm{E}-04$ & $2.211 \mathrm{E}-11$ & $1.634 \mathrm{E}-07$ & $6.689 \mathrm{E}-05$ \\
\hline AC8 & $1.216 \mathrm{E}+02$ & $6.731 \mathrm{E}-01$ & $5.171 \mathrm{E}+00$ & $9.283 \mathrm{E}-04$ & $5.892 \mathrm{E}-11$ & $9.488 \mathrm{E}-08$ & $6.134 \mathrm{E}-05$ \\
\hline Q-V & \multicolumn{5}{|c|}{ Rampdown } & \multicolumn{2}{|c|}{ Rampup } \\
\hline $\mathrm{AC}$ & $\mathrm{b}(0) \_\mathrm{Q}($ run $)$ & b(1)_Q(run) & $\mathrm{b}(2) \_\mathrm{Q}$ (run) & b(3)_Q(run) & b(4)_Q(run) & $\mathrm{k}(1) \_\mathrm{Q}(\mathrm{rec})$ & $\mathrm{k}(2) \_\mathrm{Q}(\mathrm{rec})$ \\
\hline $\mathrm{AC} 10$ & $1.117 \mathrm{E}+02$ & $9.793 \mathrm{E}-02$ & $3.039 \mathrm{E}+00$ & $-1.786 \mathrm{E}-05$ & $5.821 \mathrm{E}-10$ & $-1.007 \mathrm{E}-07$ & $9.125 \mathrm{E}-05$ \\
\hline $\mathrm{AC} 3$ & $1.211 \mathrm{E}+02$ & $1.313 \mathrm{E}-01$ & $3.576 \mathrm{E}+00$ & $-8.665 \mathrm{E}-04$ & $1.189 \mathrm{E}-09$ & $2.790 \mathrm{E}-09$ & $6.754 \mathrm{E}-05$ \\
\hline $\mathrm{AC} 4$ & $1.258 \mathrm{E}+02$ & $1.303 \mathrm{E}-01$ & $2.507 \mathrm{E}+00$ & $-1.508 \mathrm{E}-03$ & $1.126 \mathrm{E}-09$ & $-6.101 \mathrm{E}-08$ & 7.387E-05 \\
\hline AC5 & $1.039 \mathrm{E}+02$ & $1.500 \mathrm{E}-01$ & $3.437 \mathrm{E}+00$ & $-1.447 \mathrm{E}-03$ & $7.102 \mathrm{E}-10$ & $-3.010 \mathrm{E}-08$ & $1.021 \mathrm{E}-04$ \\
\hline AC6 & $1.126 \mathrm{E}+02$ & $1.069 \mathrm{E}-01$ & $4.201 \mathrm{E}+00$ & $3.015 \mathrm{E}-04$ & $1.222 \mathrm{E}-09$ & $-2.223 \mathrm{E}-08$ & $7.123 \mathrm{E}-05$ \\
\hline AC7 & $1.033 \mathrm{E}+02$ & $1.298 \mathrm{E}-02$ & $5.508 \mathrm{E}+00$ & $9.923 \mathrm{E}-05$ & $4.525 \mathrm{E}-10$ & $-5.697 \mathrm{E}-08$ & $9.072 \mathrm{E}-05$ \\
\hline AC8 & $1.261 \mathrm{E}+02$ & $9.307 \mathrm{E}-02$ & $3.840 \mathrm{E}+00$ & $-4.378 \mathrm{E}-04$ & $1.820 \mathrm{E}-09$ & $-2.706 \mathrm{E}-08$ & $6.971 \mathrm{E}-05$ \\
\hline
\end{tabular}

\begin{tabular}{|c|c|c|}
\hline V critical & Rampdown & Rampup \\
\hline AC & peak_V(run) & peak_V(rec) \\
\hline AC10 & $1.164 \mathrm{E}+02$ & $2.009 \mathrm{E}+02$ \\
AC3 & $1.257 \mathrm{E}+02$ & $1.721 \mathrm{E}+02$ \\
AC4 & $1.300 \mathrm{E}+02$ & $2.300 \mathrm{E}+02$ \\
AC5 & $1.104 \mathrm{E}+02$ & $2.057 \mathrm{E}+02$ \\
AC6 & $1.185 \mathrm{E}+02$ & $1.700 \mathrm{E}+02$ \\
AC7 & $1.105 \mathrm{E}+02$ & $1.638 \mathrm{E}+02$ \\
AC8 & $1.301 \mathrm{E}+02$ & $1.769 \mathrm{E}+02$ \\
\hline
\end{tabular}

\section{At $100^{\circ} \mathrm{F}$}

\begin{tabular}{|c|c|c|c|c|c|c|c|}
\hline \multirow{2}{*}{$\begin{array}{l}\mathbf{P}-\mathbf{V} \\
\mathrm{AC}\end{array}$} & \multicolumn{5}{|c|}{ Rampdown } & \multicolumn{2}{|c|}{ Rampup } \\
\hline & $\mathrm{b}(0) \mathrm{P}($ run $)$ & $\mathrm{b}(1) \mathrm{P}$ (run) & $\mathrm{b}(2) \mathrm{P}($ run $)$ & $\mathrm{b}$ (3) $\mathrm{P}$ (run) & $\mathrm{b}(4) \mathrm{P}$ (run) & $\mathrm{k}(1) \mathrm{P}(\mathrm{rec})$ & $\mathrm{k}(2) \mathrm{P}(\mathrm{rec})$ \\
\hline $\mathrm{AC} 10$ & $1.242 \mathrm{E}+02$ & $8.652 \mathrm{E}-01$ & $4.957 \mathrm{E}+00$ & $2.348 \mathrm{E}-04$ & $1.207 \mathrm{E}-10$ & $4.587 \mathrm{E}-08$ & $8.220 \mathrm{E}-05$ \\
\hline $\mathrm{AC} 3$ & $1.356 \mathrm{E}+02$ & $9.004 \mathrm{E}-01$ & $3.509 \mathrm{E}+00$ & $-2.676 \mathrm{E}-04$ & $3.877 \mathrm{E}-10$ & $1.220 \mathrm{E}-07$ & $5.560 \mathrm{E}-05$ \\
\hline $\mathrm{AC} 4$ & $1.416 \mathrm{E}+02$ & $8.753 \mathrm{E}-01$ & $4.514 \mathrm{E}+00$ & $2.801 \mathrm{E}-04$ & $2.987 \mathrm{E}-10$ & $1.582 \mathrm{E}-07$ & $4.349 \mathrm{E}-05$ \\
\hline AC5 & $1.248 \mathrm{E}+02$ & $1.008 \mathrm{E}+00$ & $1.214 \mathrm{E}+00$ & $-1.167 \mathrm{E}-03$ & $6.556 \mathrm{E}-10$ & $1.778 \mathrm{E}-07$ & $5.400 \mathrm{E}-05$ \\
\hline AC6 & $1.250 \mathrm{E}+02$ & $7.312 \mathrm{E}-01$ & $5.520 \mathrm{E}+00$ & $5.158 \mathrm{E}-04$ & $1.719 \mathrm{E}-10$ & $1.208 \mathrm{E}-07$ & $5.445 \mathrm{E}-05$ \\
\hline AC7 & $1.162 \mathrm{E}+02$ & $8.222 \mathrm{E}-01$ & $5.863 \mathrm{E}+00$ & $6.494 \mathrm{E}-04$ & $7.582 \mathrm{E}-11$ & $1.593 \mathrm{E}-07$ & $6.684 \mathrm{E}-05$ \\
\hline $\mathrm{AC} 8$ & $1.303 \mathrm{E}+02$ & $7.285 \mathrm{E}-01$ & $6.476 \mathrm{E}+00$ & $1.368 \mathrm{E}-03$ & $-1.142 \mathrm{E}-10$ & $8.812 \mathrm{E}-08$ & $6.217 \mathrm{E}-05$ \\
\hline Q-V & & & Rampdown & & & & \\
\hline $\mathrm{AC}$ & $\mathrm{b}(0) \_\mathrm{Q}$ (run) & $\mathrm{b}(1) \_\mathrm{Q}$ (run) & $\mathrm{b}(2) \_\mathrm{Q}$ (run) & $\mathrm{b}(3) \_\mathrm{Q}$ (run) & $\mathrm{b}(4) \_\mathrm{Q}(\mathrm{run})$ & $\mathrm{k}(1) \_\mathrm{Q}(\mathrm{rec})$ & $\mathrm{k}(2) \_\mathrm{Q}(\mathrm{rec})$ \\
\hline $\mathrm{AC} 10$ & $1.275 \mathrm{E}+02$ & $1.117 \mathrm{E}-01$ & $4.087 \mathrm{E}+00$ & $6.314 \mathrm{E}-06$ & $9.230 \mathrm{E}-10$ & $-8.693 \mathrm{E}-08$ & $8.345 \mathrm{E}-05$ \\
\hline $\mathrm{AC} 3$ & $1.386 \mathrm{E}+02$ & $2.364 \mathrm{E}-01$ & $2.970 \mathrm{E}+00$ & $-1.847 \mathrm{E}-03$ & $2.339 \mathrm{E}-09$ & $-1.063 \mathrm{E}-08$ & $6.994 \mathrm{E}-05$ \\
\hline $\mathrm{AC} 4$ & $1.454 \mathrm{E}+02$ & $1.693 \mathrm{E}-01$ & $3.797 \mathrm{E}+00$ & $-2.001 \mathrm{E}-03$ & $2.278 \mathrm{E}-09$ & $8.129 \mathrm{E}-08$ & $5.276 \mathrm{E}-05$ \\
\hline AC5 & $1.243 \mathrm{E}+02$ & $2.470 \mathrm{E}-01$ & $3.493 \mathrm{E}+00$ & $-2.361 \mathrm{E}-03$ & $1.437 \mathrm{E}-09$ & $-1.333 \mathrm{E}-08$ & $9.517 \mathrm{E}-05$ \\
\hline AC6 & $1.302 \mathrm{E}+02$ & $1.789 \mathrm{E}-01$ & $4.056 \mathrm{E}+00$ & $3.951 \mathrm{E}-05$ & 2.034E-09 & $-2.009 \mathrm{E}-08$ & $6.789 \mathrm{E}-05$ \\
\hline $\mathrm{AC} 7$ & $1.213 \mathrm{E}+02$ & $9.954 \mathrm{E}-02$ & $5.092 \mathrm{E}+00$ & $-8.265 \mathrm{E}-04$ & $1.072 \mathrm{E}-09$ & $-3.537 \mathrm{E}-08$ & $8.422 \mathrm{E}-05$ \\
\hline AC8 & $1.339 \mathrm{E}+02$ & $4.176 \mathrm{E}-02$ & $5.564 \mathrm{E}+00$ & $4.058 \mathrm{E}-04$ & $1.917 \mathrm{E}-09$ & $-2.536 \mathrm{E}-08$ & $6.853 \mathrm{E}-05$ \\
\hline
\end{tabular}

\begin{tabular}{|c|c|c|}
\hline V critical & Rampdown & Rampup \\
\hline AC & peak_V(run) & peak_V(rec) \\
\hline AC10 & $1.320 \mathrm{E}+02$ & $1.960 \mathrm{E}+02$ \\
AC3 & $1.426 \mathrm{E}+02$ & $1.728 \mathrm{E}+02$ \\
AC4 & $1.489 \mathrm{E}+02$ & $9.049 \mathrm{E}+01$ \\
AC5 & $1.297 \mathrm{E}+02$ & $1.915 \mathrm{E}+02$ \\
AC6 & $1.345 \mathrm{E}+02$ & $1.723 \mathrm{E}+02$ \\
AC7 & $1.262 \mathrm{E}+02$ & $1.664 \mathrm{E}+02$ \\
AC8 & $1.384 \mathrm{E}+02$ & $1.769 \mathrm{E}+02$ \\
\hline
\end{tabular}


Tab;le B.2. Continued

\begin{tabular}{|c|c|c|c|c|c|c|c|}
\hline \multirow{2}{*}{$\begin{array}{l}\mathbf{P}-\mathbf{V} \\
\mathrm{AC} \\
\end{array}$} & \multicolumn{5}{|c|}{ Rampdown } & \multicolumn{2}{|c|}{ Rampup } \\
\hline & $\mathrm{b}(0) \_\mathrm{P}($ run $)$ & b(1)_P(run) & $\mathrm{b}(2) \_\mathrm{P}($ run $)$ & $\mathrm{b}(3) \_\mathrm{P}($ run $)$ & $\mathrm{b}(4) \_\mathrm{P}(\mathrm{run})$ & $\mathrm{k}(1) \_\mathrm{P}(\mathrm{rec})$ & $\mathrm{k}(2) \mathrm{P}(\mathrm{rec})$ \\
\hline $\mathrm{AC} 10$ & $1.324 \mathrm{E}+02$ & $7.908 \mathrm{E}-01$ & $1.313 \mathrm{E}+01$ & $2.463 \mathrm{E}-03$ & $-4.623 \mathrm{E}-10$ & $1.189 \mathrm{E}-07$ & $7.070 \mathrm{E}-05$ \\
\hline $\mathrm{AC} 3$ & $1.398 \mathrm{E}+02$ & $7.475 \mathrm{E}-01$ & $1.316 \mathrm{E}+01$ & $3.022 \mathrm{E}-03$ & $-8.006 \mathrm{E}-10$ & $1.176 \mathrm{E}-07$ & $5.620 \mathrm{E}-05$ \\
\hline $\mathrm{AC} 4$ & $1.595 \mathrm{E}+02$ & $1.092 \mathrm{E}+00$ & $4.725 \mathrm{E}+00$ & $2.998 \mathrm{E}-04$ & $2.528 \mathrm{E}-10$ & $1.588 \mathrm{E}-07$ & 4.313E-05 \\
\hline AC5 & $1.383 \mathrm{E}+02$ & $1.134 \mathrm{E}+00$ & $5.867 \mathrm{E}+00$ & $3.163 \mathrm{E}-04$ & $1.063 \mathrm{E}-10$ & $1.792 \mathrm{E}-07$ & $5.432 \mathrm{E}-05$ \\
\hline AC6 & $1.360 \mathrm{E}+02$ & $7.485 \mathrm{E}-01$ & $1.034 \mathrm{E}+01$ & $1.970 \mathrm{E}-03$ & $-2.616 \mathrm{E}-10$ & $9.860 \mathrm{E}-08$ & $5.731 \mathrm{E}-05$ \\
\hline AC7 & $1.323 \mathrm{E}+02$ & $1.025 \mathrm{E}+00$ & $5.567 \mathrm{E}+00$ & $3.087 \mathrm{E}-04$ & $1.662 \mathrm{E}-10$ & $1.270 \mathrm{E}-07$ & $7.080 \mathrm{E}-05$ \\
\hline $\mathrm{AC} 8$ & $1.438 \mathrm{E}+02$ & $9.249 \mathrm{E}-01$ & $3.848 \mathrm{E}+00$ & $2.673 \mathrm{E}-04$ & $2.686 \mathrm{E}-10$ & $1.001 \mathrm{E}-07$ & $6.028 \mathrm{E}-05$ \\
\hline Q-V & \multicolumn{5}{|c|}{ Rampdown } & \multicolumn{2}{|c|}{ Rampup } \\
\hline $\mathrm{AC}$ & $\mathrm{b}(0) \_\mathrm{Q}$ (run) & b(1)_Q(run) & $\mathrm{b}(2) \_\mathrm{Q}$ (run) & b(3)_Q(run) & b(4)_Q(run) & $\mathrm{k}(1) \_\mathrm{Q}(\mathrm{rec})$ & $\mathrm{k}(2) \_\mathrm{Q}(\mathrm{rec})$ \\
\hline $\mathrm{AC} 10$ & $1.394 \mathrm{E}+02$ & $3.970 \mathrm{E}-02$ & $7.261 \mathrm{E}+00$ & $1.135 \mathrm{E}-03$ & $8.650 \mathrm{E}-10$ & $-3.938 \mathrm{E}-08$ & $7.331 \mathrm{E}-05$ \\
\hline $\mathrm{AC} 3$ & $1.468 \mathrm{E}+02$ & $4.177 \mathrm{E}-02$ & $8.841 \mathrm{E}+00$ & $1.039 \mathrm{E}-03$ & $1.230 \mathrm{E}-09$ & $-1.184 \mathrm{E}-08$ & $7.115 \mathrm{E}-05$ \\
\hline AC4 & $1.625 \mathrm{E}+02$ & $2.495 \mathrm{E}-01$ & $3.847 \mathrm{E}+00$ & $-2.751 \mathrm{E}-03$ & 4.372E-09 & $1.170 \mathrm{E}-07$ & $5.046 \mathrm{E}-05$ \\
\hline AC5 & $1.432 \mathrm{E}+02$ & $3.004 \mathrm{E}-01$ & $5.348 \mathrm{E}+00$ & $-2.664 \mathrm{E}-03$ & $2.460 \mathrm{E}-09$ & $1.320 \mathrm{E}-08$ & $8.669 \mathrm{E}-05$ \\
\hline AC6 & $1.424 \mathrm{E}+02$ & $1.233 \mathrm{E}-01$ & $7.001 \mathrm{E}+00$ & $1.312 \mathrm{E}-03$ & $2.212 \mathrm{E}-09$ & $-7.976 \mathrm{E}-08$ & 7.525E-05 \\
\hline AC7 & $1.363 \mathrm{E}+02$ & $1.944 \mathrm{E}-01$ & $4.411 \mathrm{E}+00$ & $-1.861 \mathrm{E}-03$ & $2.120 \mathrm{E}-09$ & $-9.784 \mathrm{E}-08$ & 8.889E-05 \\
\hline AC8 & $1.453 \mathrm{E}+02$ & $1.391 \mathrm{E}-01$ & $3.752 \mathrm{E}+00$ & $-3.121 \mathrm{E}-04$ & $3.072 \mathrm{E}-09$ & $-1.212 \mathrm{E}-08$ & $6.577 \mathrm{E}-05$ \\
\hline
\end{tabular}

\begin{tabular}{|c|c|c|}
\hline V critical & Rampdown & Rampup \\
\hline AC & peak_V(run) & peak_V(rec) \\
\hline AC10 & $1.444 \mathrm{E}+02$ & $1.639 \mathrm{E}+02$ \\
AC3 & $1.530 \mathrm{E}+02$ & $1.776 \mathrm{E}+02$ \\
AC4 & $1.655 \mathrm{E}+02$ & $9.065 \mathrm{E}+01$ \\
AC5 & $1.471 \mathrm{E}+02$ & $1.739 \mathrm{E}+02$ \\
AC6 & $1.481 \mathrm{E}+02$ & $1.805 \mathrm{E}+02$ \\
AC7 & $1.398 \mathrm{E}+02$ & $1.698 \mathrm{E}+02$ \\
AC8 & $1.480 \mathrm{E}+02$ & $1.678 \mathrm{E}+02$ \\
\hline
\end{tabular}


Table B.3. Parameters of Second-Order Polynomial Fitting on Curve-Fitting Parameters of the Three Temperatures Based on Raw Filtered Data

\begin{tabular}{|c|c|c|c|c|c|c|c|c|c|c|c|c|c|c|c|c|c|}
\hline \multirow{2}{*}{$\begin{array}{c}\mathrm{AC} \\
\text { index }\end{array}$} & \multirow{2}{*}{$\begin{array}{c}\text { polynomial } \\
\text { parameter }\end{array}$} & \multicolumn{5}{|c|}{ Rampdown P-V } & \multicolumn{5}{|c|}{ Rampdown Q-V } & \multicolumn{2}{|c|}{ Rampup P-V } & \multicolumn{2}{|c|}{ Rampup Q-V } & \multicolumn{2}{|c|}{ Critical V } \\
\hline & & $\mathrm{b}(0)$ & $\mathrm{b}(1)$ & $b(2)$ & $b(3)$ & $\mathrm{b}(4)$ & $\mathrm{b}(0)$ & $\mathrm{b}(1)$ & $\mathrm{b}(2)$ & $\mathrm{b}(3)$ & $\mathrm{b}(4)$ & $\mathrm{k}(1)$ & $\mathrm{k}(2)$ & $\mathrm{k}(1)$ & $k(2)$ & Rampdown & Rampup \\
\hline $\mathrm{AC} 10$ & P0 & $7.39 \mathrm{E}+00$ & $-1.43 E+04$ & $5.43 \mathrm{E}+05$ & $1.96 \mathrm{E}+02$ & $-5.22 \mathrm{E}-05$ & $4.95 \mathrm{E}+01$ & $-7.19 \mathrm{E}+03$ & $2.09 \mathrm{E}+05$ & $9.99 \mathrm{E}+01$ & $-3.30 \mathrm{E}-05$ & $8.26 \mathrm{E}-03$ & $-6.46 \mathrm{E}-01$ & $2.45 \mathrm{E}-03$ & 3.40E-01 & $6.60 \mathrm{E}+01$ & $-2.14 \mathrm{E}+02$ \\
\hline $\mathrm{AC} 10$ & P1 & $1.71 \mathrm{E}+00$ & $3.89 \mathrm{E}+02$ & $-1.24 \mathrm{E}+04$ & $-4.41 \mathrm{E}+00$ & $1.19 \mathrm{E}-06$ & $7.70 \mathrm{E}-01$ & $1.72 \mathrm{E}+02$ & $-4.55 \mathrm{E}+03$ & $-2.25 \mathrm{E}+00$ & $7.40 \mathrm{E}-07$ & $-1.74 \mathrm{E}-04$ & $2.52 \mathrm{E}-02$ & $-7.18 \mathrm{E}-05$ & $6.39 \mathrm{E}-03$ & $5.14 \mathrm{E}-01$ & $9.53 \mathrm{E}+00$ \\
\hline $\mathrm{AC} 10$ & $\mathrm{P} 2$ & $-5.40 \mathrm{E}-03$ & $-1.94 \mathrm{E}+00$ & $7.28 \mathrm{E}+01$ & $2.46 \mathrm{E}-02$ & $-6.61 \mathrm{E}-09$ & $1.06 \mathrm{E}-04$ & $-9.31 \mathrm{E}-01$ & $2.70 \mathrm{E}+01$ & $1.26 \mathrm{E}-02$ & $-3.55 \mathrm{E}-09$ & $9.46 \mathrm{E}-07$ & $-1.38 \mathrm{E}-04$ & 4.21E- 07 & $-4.84 \mathrm{E}-05$ & $1.46 \mathrm{E}-03$ & $-5.43 \mathrm{E}-02$ \\
\hline $\mathrm{AC} 3$ & P0 & $-1.48 \mathrm{E}+02$ & $-2.48 \mathrm{E}+04$ & $7.49 \mathrm{E}+05$ & $2.77 \mathrm{E}+02$ & $-9.60 \mathrm{E}-05$ & $-2.38 \mathrm{E}+01$ & $-1.80 \mathrm{E}+04$ & $4.13 \mathrm{E}+05$ & $2.35 \mathrm{E}+02$ & $-1.35 \mathrm{E}-04$ & $1.06 \mathrm{E}-03$ & $1.53 \mathrm{E}-01$ & $7.72 \mathrm{E}-04$ & $1.98 \mathrm{E}-01$ & $2.23 \mathrm{E}+01$ & $2.34 \mathrm{E}+02$ \\
\hline $\mathrm{AC} 3$ & P1 & $5.06 \mathrm{E}+00$ & $5.67 \mathrm{E}+02$ & $-1.60 \mathrm{E}+04$ & $-5.96 \mathrm{E}+00$ & $2.10 \mathrm{E}-06$ & $2.56 \mathrm{E}+00$ & $3.99 \mathrm{E}+02$ & $-8.87 \mathrm{E}+03$ & $-5.20 \mathrm{E}+00$ & $2.96 \mathrm{E}-06$ & $-9.53 \mathrm{E}-06$ & $1.20 \mathrm{E}-03$ & $-1.50 \mathrm{E}-05$ & $1.29 \mathrm{E}-03$ & $1.65 \mathrm{E}+00$ & $-1.42 \mathrm{E}+00$ \\
\hline $\mathrm{AC} 3$ & $\mathrm{P} 2$ & $-2.23 \mathrm{E}-02$ & $-2.83 \mathrm{E}+00$ & $8.65 \mathrm{E}+01$ & $3.18 \mathrm{E}-02$ & $-1.13 \mathrm{E}-08$ & $-9.37 \mathrm{E}-03$ & $-2.10 \mathrm{E}+00$ & $4.86 \mathrm{E}+01$ & $2.78 \mathrm{E}-02$ & $-1.51 \mathrm{E}-08$ & $3.88 \mathrm{E}-08$ & $-4.81 \mathrm{E}-06$ & $6.81 \mathrm{E}-08$ & $-4.50 \mathrm{E}-06$ & $-4.44 \mathrm{E}-03$ & $8.09 \mathrm{E}-03$ \\
\hline $\mathrm{AC} 4$ & P0 & $1.13 \mathrm{E}+02$ & $4.54 \mathrm{E}+03$ & $-1.05 E+05$ & $-1.33 \mathrm{E}+01$ & $-2.24 \mathrm{E}-06$ & $8.33 \mathrm{E}+01$ & $2.67 \mathrm{E}+03$ & $-5.91 \mathrm{E}+04$ & $-1.89 \mathrm{E}+01$ & $5.42 \mathrm{E}-05$ & $-2.67 \mathrm{E}-03$ & $5.94 \mathrm{E}-01$ & $-6.09 \mathrm{E}-03$ & $1.30 \mathrm{E}+00$ & $9.13 \mathrm{E}+01$ & $2.39 \mathrm{E}+03$ \\
\hline $\mathrm{AC} 4$ & P1 & $-4.94 \mathrm{E}-01$ & $-7.14 \mathrm{E}+01$ & $2.22 \mathrm{E}+03$ & $2.63 \mathrm{E}-01$ & 7.11E-08 & $1.71 \mathrm{E}-01$ & $-5.51 \mathrm{E}+01$ & $1.35 \mathrm{E}+03$ & $3.75 \mathrm{E}-01$ & $-1.29 \mathrm{E}-06$ & $6.03 \mathrm{E}-05$ & $-8.15 \mathrm{E}-03$ & $1.12 \mathrm{E}-04$ & $-2.03 \mathrm{E}-02$ & $1.16 \mathrm{E}-01$ & $-4.29 \mathrm{E}+01$ \\
\hline $\mathrm{AC} 4$ & $\mathrm{P} 2$ & $7.82 \mathrm{E}-03$ & $5.71 \mathrm{E}-01$ & $-1.01 \mathrm{E}+01$ & $-1.20 \mathrm{E}-03$ & $-3.81 \mathrm{E}-10$ & $4.50 \mathrm{E}-03$ & $3.45 \mathrm{E}-01$ & $-6.21 \mathrm{E}+00$ & $-2.57 \mathrm{E}-03$ & $8.32 \mathrm{E}-09$ & $-2.80 \mathrm{E}-07$ & $3.75 \mathrm{E}-05$ & $-4.81 \mathrm{E}-07$ & $9.17 \mathrm{E}-05$ & 4.60E-03 & $2.00 \mathrm{E}-01$ \\
\hline AC5 & P0 & $-1.04 \mathrm{E}+02$ & $-1.00 \mathrm{E}+04$ & $4.38 \mathrm{E}+05$ & $1.86 \mathrm{E}+02$ & $-7.31 \mathrm{E}-05$ & $7.64 \mathrm{E}+01$ & $-2.63 \mathrm{E}+03$ & $1.52 \mathrm{E}+05$ & $3.96 \mathrm{E}+01$ & $2.50 \mathrm{E}-05$ & $1.21 \mathrm{E}-03$ & $2.02 \mathrm{E}-01$ & $5.68 \mathrm{E}-04$ & $3.91 \mathrm{E}-01$ & $7.79 \mathrm{E}+01$ & $1.57 \mathrm{E}+02$ \\
\hline AC5 & P1 & $3.49 \mathrm{E}+00$ & $2.44 \mathrm{E}+02$ & $-9.41 E+03$ & $-4.01 \mathrm{E}+00$ & $1.58 \mathrm{E}-06$ & $-1.99 \mathrm{E}-01$ & $5.66 \mathrm{E}+01$ & $-3.05 E+03$ & $-8.71 \mathrm{E}-01$ & $-6.27 \mathrm{E}-07$ & $-6.56 \mathrm{E}-06$ & $1.10 \mathrm{E}-03$ & $-1.94 \mathrm{E}-05$ & $3.89 \mathrm{E}-03$ & $-3.80 \mathrm{E}-02$ & $1.65 \mathrm{E}+00$ \\
\hline $\mathrm{AC} 5$ & P2 & $-1.21 \mathrm{E}-02$ & $-9.46 \mathrm{E}-01$ & $5.09 \mathrm{E}+01$ & $2.09 \mathrm{E}-02$ & $-8.21 \mathrm{E}-09$ & $6.78 \mathrm{E}-03$ & $-1.82 \mathrm{E}-01$ & $1.70 \mathrm{E}+01$ & $3.59 \mathrm{E}-03$ & $4.48 \mathrm{E}-09$ & $3.27 \mathrm{E}-08$ & $-4.64 \mathrm{E}-06$ & $1.31 \mathrm{E}-07$ & $-3.11 \mathrm{E}-05$ & $5.56 \mathrm{E}-03$ & $-1.31 \mathrm{E}-02$ \\
\hline AC6 & P0 & $-3.25 \mathrm{E}+01$ & $-1.06 \mathrm{E}+04$ & $4.33 \mathrm{E}+05$ & $1.42 \mathrm{E}+02$ & $-4.30 \mathrm{E}-05$ & $2.60 \mathrm{E}+01$ & $-9.64 E+03$ & $2.67 \mathrm{E}+05$ & $1.23 \mathrm{E}+02$ & $-4.48 \mathrm{E}-05$ & $-1.07 \mathrm{E}-04$ & 4.33E-01 & $-5.02 \mathrm{E}-03$ & $1.22 \mathrm{E}+00$ & $7.74 \mathrm{E}+01$ & $2.60 \mathrm{E}+02$ \\
\hline AC6 & P1 & $2.31 \mathrm{E}+00$ & $2.64 \mathrm{E}+02$ & $-9.01 E+03$ & $-3.05 E+00$ & $9.52 \mathrm{E}-07$ & $1.25 \mathrm{E}+00$ & $2.14 \mathrm{E}+02$ & $-5.48 \mathrm{E}+03$ & $-2.69 \mathrm{E}+00$ & $9.81 \mathrm{E}-07$ & $2.05 \mathrm{E}-05$ & $-3.67 \mathrm{E}-03$ & $1.10 \mathrm{E}-04$ & $-1.85 \mathrm{E}-02$ & $2.80 \mathrm{E}-01$ & $-2.11 \mathrm{E}+00$ \\
\hline AC6 & $\mathrm{P} 2$ & $-7.30 \mathrm{E}-03$ & $-1.20 \mathrm{E}+00$ & $4.97 \mathrm{E}+01$ & $1.65 \mathrm{E}-02$ & $-5.13 \mathrm{E}-09$ & $-2.03 \mathrm{E}-03$ & $-1.09 \mathrm{E}+00$ & $3.02 \mathrm{E}+01$ & $1.45 \mathrm{E}-02$ & $-4.28 \mathrm{E}-09$ & $-1.31 \mathrm{E}-07$ & $2.17 \mathrm{E}-05$ & $-6.07 \mathrm{E}-07$ & $9.77 \mathrm{E}-05$ & $2.91 \mathrm{E}-03$ & $1.24 \mathrm{E}-02$ \\
\hline $\mathrm{AC7}$ & P0 & $3.59 \mathrm{E}+01$ & $1.79 \mathrm{E}+03$ & $1.05 \mathrm{E}+04$ & $8.06 \mathrm{E}-01$ & $2.51 \mathrm{E}-06$ & $5.40 \mathrm{E}+01$ & $5.38 \mathrm{E}+02$ & $6.76 \mathrm{E}+03$ & $-6.08 \mathrm{E}+00$ & $3.01 \mathrm{E}-05$ & $-1.17 \mathrm{E}-03$ & $5.62 \mathrm{E}-01$ & $-5.90 \mathrm{E}-03$ & $1.15 \mathrm{E}+00$ & $7.57 \mathrm{E}+01$ & $1.74 \mathrm{E}+02$ \\
\hline $\mathrm{AC7}$ & P1 & $5.67 \mathrm{E}-01$ & $-1.76 \mathrm{E}+01$ & $3.61 \mathrm{E}+02$ & $1.25 \mathrm{E}-01$ & $-6.37 \mathrm{E}-08$ & $3.90 \mathrm{E}-01$ & $-2.60 \mathrm{E}+01$ & $4.65 \mathrm{E}+02$ & $3.09 \mathrm{E}-01$ & $-7.41 \mathrm{E}-07$ & 4.31E-05 & $-6.02 \mathrm{E}-03$ & $1.23 \mathrm{E}-04$ & $-1.58 \mathrm{E}-02$ & $1.55 \mathrm{E}-01$ & $-3.42 \mathrm{E}-01$ \\
\hline $\mathrm{AC7}$ & $\mathrm{P} 2$ & $2.37 \mathrm{E}-03$ & $3.58 \mathrm{E}-01$ & $-2.08 \mathrm{E}+00$ & $-1.05 \mathrm{E}-03$ & $4.19 \mathrm{E}-10$ & $2.83 \mathrm{E}-03$ & $2.50 \mathrm{E}-01$ & $-3.09 \mathrm{E}+00$ & $-2.85 \mathrm{E}-03$ & $4.87 \mathrm{E}-09$ & $-2.45 \mathrm{E}-07$ & $3.34 \mathrm{E}-05$ & $-6.58 \mathrm{E}-07$ & $7.99 \mathrm{E}-05$ & $3.50 \mathrm{E}-03$ & $2.62 \mathrm{E}-03$ \\
\hline AC8 & P0 & $1.93 \mathrm{E}+02$ & $1.27 \mathrm{E}+04$ & $-2.49 \mathrm{E}+05$ & $-1.02 \mathrm{E}+02$ & $3.87 \mathrm{E}-05$ & $1.81 \mathrm{E}+02$ & $1.07 \mathrm{E}+04$ & $-2.28 \mathrm{E}+05$ & $-1.10 \mathrm{E}+02$ & $8.11 \mathrm{E}-05$ & $1.72 \mathrm{E}-03$ & $8.99 \mathrm{E}-02$ & $6.72 \mathrm{E}-04$ & $2.07 \mathrm{E}-01$ & $1.48 \mathrm{E}+02$ & $3.77 \mathrm{E}+01$ \\
\hline AC8 & P1 & $-1.96 \mathrm{E}+00$ & $-2.27 \mathrm{E}+02$ & $5.89 \mathrm{E}+03$ & $2.32 \mathrm{E}+00$ & $-8.34 \mathrm{E}-07$ & $-1.54 \mathrm{E}+00$ & $-2.22 \mathrm{E}+02$ & $5.21 \mathrm{E}+03$ & $2.29 \mathrm{E}+00$ & $-1.66 \mathrm{E}-06$ & $-2.79 \mathrm{E}-05$ & 4.07E- 03 & $-1.82 \mathrm{E}-05$ & $2.64 \mathrm{E}-03$ & $-7.43 \mathrm{E}-01$ & $3.13 \mathrm{E}+00$ \\
\hline $\mathrm{AC} 8$ & P2 & $1.33 \mathrm{E}-02$ & $1.33 \mathrm{E}+00$ & $-3.11 \mathrm{E}+01$ & $-1.23 \mathrm{E}-02$ & $4.42 \mathrm{E}-09$ & $1.07 \mathrm{E}-02$ & $1.17 \mathrm{E}+00$ & $-2.68 \mathrm{E}+01$ & $-1.16 \mathrm{E}-02$ & $9.32 \mathrm{E}-09$ & $1.46 \mathrm{E}-07$ & $-2.16 \mathrm{E}-05$ & $1.03 \mathrm{E}-07$ & $-1.62 \mathrm{E}-05$ & $6.44 \mathrm{E}-03$ & $-1.74 \mathrm{E}-02$ \\
\hline
\end{tabular}


Table B.4. Parameters of Second Order Polynomial Fitting on Curve-Fitting Parameters of the Three Temperatures Based on Normalized Filtered Data

\begin{tabular}{|c|c|c|c|c|c|c|c|c|c|c|c|c|c|c|c|c|c|}
\hline \multirow{2}{*}{$\begin{array}{c}\mathrm{AC} \\
\text { index }\end{array}$} & \multirow{2}{*}{$\begin{array}{c}\text { polynomial } \\
\text { parameter }\end{array}$} & \multicolumn{5}{|c|}{ Rampdown P-V } & \multicolumn{5}{|c|}{ Rampdown Q-V } & \multicolumn{2}{|c|}{ Rampup P-V } & \multicolumn{2}{|c|}{ Rampup Q-V } & \multicolumn{2}{|c|}{ Critical V } \\
\hline & & $\mathrm{b}(0)$ & $\mathrm{b}(1)$ & $\mathrm{b}(2)$ & $b(3)$ & $\mathrm{b}(4)$ & $\mathrm{b}(0)$ & $\mathrm{b}(1)$ & $\mathrm{b}(2)$ & $\mathrm{b}(3)$ & $\mathrm{b}(4)$ & $\mathrm{k}(1)$ & $\mathrm{k}(2)$ & $\mathrm{k}(1)$ & $\mathrm{k}(2)$ & Rampdown & Rampup \\
\hline $\mathrm{AC} 10$ & P0 & $7.39 \mathrm{E}+00$ & $-2.40 \mathrm{E}+00$ & $9.14 \mathrm{E}+01$ & $3.30 \mathrm{E}-02$ & $-8.78 \mathrm{E}-09$ & $6.60 \mathrm{E}+01$ & $4.95 \mathrm{E}+01$ & $-1.21 E+00$ & $3.52 \mathrm{E}+01$ & $1.68 \mathrm{E}-02$ & $-5.56 \mathrm{E}-09$ & $1.39 \mathrm{E}-06$ & $-1.09 \mathrm{E}-04$ & $-2.14 \mathrm{E}+02$ & $4.12 \mathrm{E}-07$ & $5.73 \mathrm{E}-05$ \\
\hline $\mathrm{AC} 10$ & P1 & $1.71 \mathrm{E}+00$ & $6.54 \mathrm{E}-02$ & $-2.09 \mathrm{E}+00$ & $-7.42 \mathrm{E}-04$ & $2.00 \mathrm{E}-10$ & $5.14 \mathrm{E}-01$ & $7.70 \mathrm{E}-01$ & $2.89 \mathrm{E}-02$ & $-7.66 \mathrm{E}-01$ & $-3.80 \mathrm{E}-04$ & $1.25 \mathrm{E}-10$ & $-2.94 \mathrm{E}-08$ & 4.24E-06 & $9.53 \mathrm{E}+00$ & $-1.21 \mathrm{E}-08$ & $1.08 \mathrm{E}-06$ \\
\hline $\mathrm{AC} 10$ & $\mathrm{P} 2$ & $-5.40 \mathrm{E}-03$ & $-3.27 \mathrm{E}-04$ & $1.23 \mathrm{E}-02$ & 4.14E-06 & $-1.11 \mathrm{E}-12$ & $1.46 \mathrm{E}-03$ & $1.06 \mathrm{E}-04$ & $-1.57 \mathrm{E}-04$ & $4.55 \mathrm{E}-03$ & $2.12 \mathrm{E}-06$ & $-5.97 \mathrm{E}-13$ & $1.59 \mathrm{E}-10$ & $-2.33 \mathrm{E}-08$ & $-5.43 \mathrm{E}-02$ & $7.09 \mathrm{E}-11$ & $-8.15 \mathrm{E}-09$ \\
\hline $\mathrm{AC} 3$ & P0 & $-1.48 \mathrm{E}+02$ & $-6.15 \mathrm{E}+00$ & $1.86 \mathrm{E}+02$ & $6.86 \mathrm{E}-02$ & $-2.38 \mathrm{E}-08$ & $2.23 \mathrm{E}+01$ & $-2.38 \mathrm{E}+01$ & $-4.46 \mathrm{E}+00$ & $1.02 \mathrm{E}+02$ & $5.83 \mathrm{E}-02$ & $-3.35 \mathrm{E}-08$ & $2.62 \mathrm{E}-07$ & 3.79E- 05 & $2.34 \mathrm{E}+02$ & $1.92 \mathrm{E}-07$ & 4.90E-05 \\
\hline $\mathrm{AC} 3$ & P1 & $5.06 \mathrm{E}+00$ & 1.41E-01 & $-3.97 \mathrm{E}+00$ & $-1.48 \mathrm{E}-03$ & $5.21 \mathrm{E}-10$ & $1.65 \mathrm{E}+00$ & $2.56 \mathrm{E}+00$ & $9.90 \mathrm{E}-02$ & $-2.20 \mathrm{E}+00$ & $-1.29 \mathrm{E}-03$ & 7.34E-10 & $-2.36 \mathrm{E}-09$ & $2.97 \mathrm{E}-07$ & $-1.42 E+00$ & $-3.71 \mathrm{E}-09$ & $3.21 \mathrm{E}-07$ \\
\hline $\mathrm{AC} 3$ & P2 & $-2.23 \mathrm{E}-02$ & $-7.02 \mathrm{E}-04$ & $2.14 \mathrm{E}-02$ & $7.90 \mathrm{E}-06$ & $-2.79 \mathrm{E}-12$ & $-4.44 \mathrm{E}-03$ & $-9.37 \mathrm{E}-03$ & $-5.21 \mathrm{E}-04$ & $1.21 \mathrm{E}-02$ & $6.90 \mathrm{E}-06$ & $-3.76 \mathrm{E}-12$ & $9.63 \mathrm{E}-12$ & $-1.19 \mathrm{E}-09$ & $8.09 \mathrm{E}-03$ & $1.69 \mathrm{E}-11$ & $-1.12 \mathrm{E}-09$ \\
\hline $\mathrm{AC} 4$ & P0 & $1.13 \mathrm{E}+02$ & $1.28 \mathrm{E}+00$ & $-2.96 \mathrm{E}+01$ & $-3.74 \mathrm{E}-03$ & $-6.29 \mathrm{E}-10$ & $9.13 \mathrm{E}+01$ & $8.33 \mathrm{E}+01$ & $7.50 \mathrm{E}-01$ & $-1.66 \mathrm{E}+01$ & $-5.32 \mathrm{E}-03$ & $1.53 \mathrm{E}-08$ & $-7.51 \mathrm{E}-07$ & $1.67 \mathrm{E}-04$ & $2.39 \mathrm{E}+03$ & $-1.71 \mathrm{E}-06$ & 3.65E-04 \\
\hline $\mathrm{AC} 4$ & P1 & $-4.94 \mathrm{E}-01$ & $-2.01 \mathrm{E}-02$ & $6.25 \mathrm{E}-01$ & 7.40E-05 & $2.00 \mathrm{E}-11$ & $1.16 \mathrm{E}-01$ & $1.71 \mathrm{E}-01$ & $-1.55 \mathrm{E}-02$ & $3.79 \mathrm{E}-01$ & $1.06 \mathrm{E}-04$ & $-3.64 \mathrm{E}-10$ & $1.70 \mathrm{E}-08$ & $-2.29 \mathrm{E}-06$ & $-4.29 \mathrm{E}+01$ & $3.15 \mathrm{E}-08$ & $-5.70 \mathrm{E}-06$ \\
\hline $\mathrm{AC4}$ & P2 & $7.82 \mathrm{E}-03$ & $1.61 \mathrm{E}-04$ & $-2.84 \mathrm{E}-03$ & $-3.38 \mathrm{E}-07$ & $-1.07 \mathrm{E}-13$ & $4.60 \mathrm{E}-03$ & $4.50 \mathrm{E}-03$ & $9.70 \mathrm{E}-05$ & $-1.75 \mathrm{E}-03$ & $-7.23 \mathrm{E}-07$ & $2.34 \mathrm{E}-12$ & $-7.87 \mathrm{E}-11$ & $1.06 \mathrm{E}-08$ & $2.00 \mathrm{E}-01$ & $-1.35 \mathrm{E}-10$ & $2.58 \mathrm{E}-08$ \\
\hline AC5 & P0 & $-1.04 \mathrm{E}+02$ & $-2.03 E+00$ & $8.89 \mathrm{E}+01$ & $3.77 \mathrm{E}-02$ & $-1.48 \mathrm{E}-08$ & $7.79 \mathrm{E}+01$ & $7.64 \mathrm{E}+01$ & $-5.33 \mathrm{E}-01$ & $3.09 \mathrm{E}+01$ & $8.03 \mathrm{E}-03$ & $5.07 \mathrm{E}-09$ & $2.45 \mathrm{E}-07$ & $4.10 \mathrm{E}-05$ & $1.57 \mathrm{E}+02$ & $1.15 \mathrm{E}-07$ & $7.92 \mathrm{E}-05$ \\
\hline AC5 & P1 & $3.49 \mathrm{E}+00$ & $4.96 \mathrm{E}-02$ & $-1.91 \mathrm{E}+00$ & $-8.13 \mathrm{E}-04$ & $3.21 \mathrm{E}-10$ & $-3.80 \mathrm{E}-02$ & $-1.99 \mathrm{E}-01$ & $1.15 \mathrm{E}-02$ & $-6.19 \mathrm{E}-01$ & $-1.77 \mathrm{E}-04$ & $-1.27 \mathrm{E}-10$ & $-1.33 \mathrm{E}-09$ & $2.24 \mathrm{E}-07$ & $1.65 \mathrm{E}+00$ & $-3.94 \mathrm{E}-09$ & $7.90 \mathrm{E}-07$ \\
\hline AC5 & P2 & $-1.21 \mathrm{E}-02$ & $-1.92 \mathrm{E}-04$ & $1.03 \mathrm{E}-02$ & $4.24 \mathrm{E}-06$ & $-1.67 \mathrm{E}-12$ & $5.56 \mathrm{E}-03$ & $6.78 \mathrm{E}-03$ & $-3.69 \mathrm{E}-05$ & $3.46 \mathrm{E}-03$ & $7.28 \mathrm{E}-07$ & $9.09 \mathrm{E}-13$ & $6.63 \mathrm{E}-12$ & $-9.42 \mathrm{E}-10$ & $-1.31 \mathrm{E}-02$ & $2.66 \mathrm{E}-11$ & $-6.30 \mathrm{E}-09$ \\
\hline AC6 & P0 & $-3.25 \mathrm{E}+01$ & $-2.04 \mathrm{E}+00$ & $8.33 \mathrm{E}+01$ & $2.73 \mathrm{E}-02$ & $-8.27 \mathrm{E}-09$ & $7.74 \mathrm{E}+01$ & $2.60 \mathrm{E}+01$ & $-1.85 \mathrm{E}+00$ & $5.13 \mathrm{E}+01$ & $2.37 \mathrm{E}-02$ & $-8.60 \mathrm{E}-09$ & $-2.06 \mathrm{E}-08$ & $8.33 \mathrm{E}-05$ & $2.60 \mathrm{E}+02$ & $-9.64 \mathrm{E}-07$ & $2.35 \mathrm{E}-04$ \\
\hline AC6 & P1 & $2.31 \mathrm{E}+00$ & $5.07 \mathrm{E}-02$ & $-1.73 \mathrm{E}+00$ & $-5.86 \mathrm{E}-04$ & $1.83 \mathrm{E}-10$ & $2.80 \mathrm{E}-01$ & $1.25 \mathrm{E}+00$ & $4.12 \mathrm{E}-02$ & $-1.05 \mathrm{E}+00$ & $-5.17 \mathrm{E}-04$ & $1.89 \mathrm{E}-10$ & 3.93E-09 & $-7.06 \mathrm{E}-07$ & $-2.11 \mathrm{E}+00$ & $2.11 \mathrm{E}-08$ & $-3.55 \mathrm{E}-06$ \\
\hline $\mathrm{AC} 6$ & P2 & $-7.30 \mathrm{E}-03$ & $-2.31 \mathrm{E}-04$ & $9.55 \mathrm{E}-03$ & $3.17 \mathrm{E}-06$ & $-9.86 \mathrm{E}-13$ & $2.91 \mathrm{E}-03$ & $-2.03 \mathrm{E}-03$ & $-2.09 \mathrm{E}-04$ & $5.82 \mathrm{E}-03$ & $2.80 \mathrm{E}-06$ & $-8.22 \mathrm{E}-13$ & $-2.52 \mathrm{E}-11$ & $4.17 \mathrm{E}-09$ & $1.24 \mathrm{E}-02$ & $-1.17 \mathrm{E}-10$ & $1.88 \mathrm{E}-08$ \\
\hline $\mathrm{AC} 7$ & P0 & $3.59 \mathrm{E}+01$ & 4.08E-01 & $2.38 \mathrm{E}+00$ & $1.84 \mathrm{E}-04$ & $5.71 \mathrm{E}-10$ & $7.57 \mathrm{E}+01$ & $5.40 \mathrm{E}+01$ & $1.22 \mathrm{E}-01$ & $1.54 \mathrm{E}+00$ & $-1.38 \mathrm{E}-03$ & $6.84 \mathrm{E}-09$ & $-2.66 \mathrm{E}-07$ & $1.28 \mathrm{E}-04$ & $1.74 \mathrm{E}+02$ & $-1.34 \mathrm{E}-06$ & 2.62E-04 \\
\hline $\mathrm{AC} 7$ & P1 & $5.67 \mathrm{E}-01$ & $-4.02 \mathrm{E}-03$ & $8.23 \mathrm{E}-02$ & $2.85 \mathrm{E}-05$ & $-1.45 \mathrm{E}-11$ & $1.55 \mathrm{E}-01$ & 3.90E-01 & $-5.93 \mathrm{E}-03$ & $1.06 \mathrm{E}-01$ & 7.04E-05 & $-1.69 \mathrm{E}-10$ & $9.82 \mathrm{E}-09$ & $-1.37 \mathrm{E}-06$ & $-3.42 \mathrm{E}-01$ & $2.81 \mathrm{E}-08$ & $-3.60 \mathrm{E}-06$ \\
\hline $\mathrm{AC7}$ & P2 & $2.37 \mathrm{E}-03$ & $8.16 \mathrm{E}-05$ & $-4.74 \mathrm{E}-04$ & $-2.38 \mathrm{E}-07$ & $9.55 \mathrm{E}-14$ & $3.50 \mathrm{E}-03$ & $2.83 \mathrm{E}-03$ & $5.70 \mathrm{E}-05$ & $-7.04 \mathrm{E}-04$ & $-6.48 \mathrm{E}-07$ & $1.11 \mathrm{E}-12$ & $-5.57 \mathrm{E}-11$ & $7.60 \mathrm{E}-09$ & $2.62 \mathrm{E}-03$ & $-1.50 \mathrm{E}-10$ & $1.82 \mathrm{E}-08$ \\
\hline $\mathrm{AC} 8$ & P0 & $1.93 \mathrm{E}+02$ & $2.81 \mathrm{E}+00$ & $-5.50 \mathrm{E}+01$ & $-2.26 \mathrm{E}-02$ & $8.56 \mathrm{E}-09$ & $1.48 \mathrm{E}+02$ & $1.81 \mathrm{E}+02$ & $2.37 \mathrm{E}+00$ & $-5.04 \mathrm{E}+01$ & $-2.44 \mathrm{E}-02$ & $1.79 \mathrm{E}-08$ & 3.81E-07 & $1.99 \mathrm{E}-05$ & $3.77 \mathrm{E}+01$ & $1.49 \mathrm{E}-07$ & $4.58 \mathrm{E}-05$ \\
\hline AC8 & P1 & $-1.96 \mathrm{E}+00$ & $-5.03 \mathrm{E}-02$ & $1.30 \mathrm{E}+00$ & $5.12 \mathrm{E}-04$ & $-1.84 \mathrm{E}-10$ & $-7.43 \mathrm{E}-01$ & $-1.54 \mathrm{E}+00$ & $-4.91 \mathrm{E}-02$ & $1.15 \mathrm{E}+00$ & $5.05 \mathrm{E}-04$ & $-3.66 \mathrm{E}-10$ & $-6.17 \mathrm{E}-09$ & $9.00 \mathrm{E}-07$ & $3.13 \mathrm{E}+00$ & $-4.02 \mathrm{E}-09$ & $5.85 \mathrm{E}-07$ \\
\hline $\mathrm{AC} 8$ & P2 & $1.33 \mathrm{E}-02$ & $2.95 \mathrm{E}-04$ & $-6.87 \mathrm{E}-03$ & $-2.72 \mathrm{E}-06$ & $9.77 \mathrm{E}-13$ & $6.44 \mathrm{E}-03$ & $1.07 \mathrm{E}-02$ & $2.59 \mathrm{E}-04$ & $-5.91 \mathrm{E}-03$ & $-2.57 \mathrm{E}-06$ & $2.06 \mathrm{E}-12$ & $3.24 \mathrm{E}-11$ & $-4.77 \mathrm{E}-09$ & $-1.74 \mathrm{E}-02$ & $2.28 \mathrm{E}-11$ & $-3.58 \mathrm{E}-09$ \\
\hline
\end{tabular}

